\title{
OS NOTARIOS E A LINGUA NOS COMEZOS DA ESCRITA DOCUMENTAL EN GALEGO
}

\author{
Ramón Lorenzo \\ Instituto da Lingua Galega (USC)
}

1. Como contribución a este Simposio decidín facer unha edición e un comentario lingüístico de dezaseis documentos de Montederramo ${ }^{1}$, que van de 1257 a 1264 e que rematan todos con fórmulas diferentes, mais sempre co mesmo notario: "Pedro Gunçáluez, que a fez" 1.18, "P. G., notario, que a escriuío" 2.17, "P. G., notario, la iscriuío" 6.16, "Eu, P. G., que la iscriuj́ et meu sinal y faço" 7.14-15, "P. G. qui notuit" 3.15, 4.21, 5.16, "Eu, P. Guncáluez, notariu de Caldelas, que a fige et meu sinno hi pugi" 8.22-23, 9.22, "Eu, P. Guncáluez, notariu públicu / ppúblicu de Caldellas / Caldelas, que esta carta fige e meu sinal hi fige" 15.13-14, 16.15-17 e outros cinco que o notario manda escribir a "Johán Eanes" 10.10-11, 11.11-12, 12.12-13, 13.1314, 14.15-17. De todos eles levan un sinal, máis ou menos idéntico, os números 7, 8, 9, 14, 15 e 16 e no número 4 aparece ó final unha man e o antebrazo. Nun principio podemos pensar que se trata do mesmo notario, mais unha análise da letra dos diferentes textos fai ver que os documentos foron escritos por diversas mans. Alén dos que puido escribir el directamente, hai outros que mandou escribir e por iso, aínda que sempre resulta problemático tratar de facer unha distinción entre os textos pola maneira como foron escritos, aventureime a facer a seguinte distribución. Parece que unha man escribiu tres documentos de 1257 (números 1-3), dúas mans diferentes escribiron dous de 1258 (números 4, 5), unha cuarta man escribiu dous de 1259 (números 6,7), unha quinta escribiu unha carta partida por abc de 1260 (números 8, 9), unha sexta escribiu catro documentos de 1259 e un de 1263 (números 10-14) e, finalmente, unha sétima man escribiu dous documentos de 1264 (números 15, 16). Sexa certa ou non esta distribución, estes textos sérvennos para ver como se ía desenvolvendo a lingua a mediados do século XIII.

1. Todos eles pertencen á Colección de documentos do mosteiro de Montederramo, de próxima publicación (Lorenzo/Pérez [no prelo]). 
2. As características destes documentos corresponden ás que se dan noutros textos galegos da mesma época. Estamos ante textos dos inicios da escrita sistemática en romance e por iso os escribáns e notarios aínda non están totalmente familiarizados coa nova situación e utilizan unha lingua con frecuentes latinismos, inclusive con frases nesta lingua, e con numerosas palabras que presentan un vocalismo ou grupos consonánticos non correspondentes ó romance. No presente comentario analizarei primeiramente as principais características gráficas, fonéticas e morfosintácticas dos documentos, despois referireime ós antropónimos e topónimos que conteñen e rematarei coa indicación das expresións latinas e latinizantes que inclúen.

\section{GRAFÍA}

A grafía destes documentos é idéntica á doutros textos galegos da mesma época.

3.1. Grafía de /i/. O normal é a grafía con $i$, como en Agín 8.21, auoençia 6.4, bispo 3.10, britar 10.6, Cima de Uila 15.3-4, Diagu 15.13, escriuir 14.16, filla 5.2, fillo 4.18, fillos 3.2, iscriuío 2.17, 6.16, 10.10, 11.11, 12.13, 13.13, iuiz 5.13, juiz 8.20, 9.20, Martín 6.13, 10.8,10, 13.10,12, mía 2.2,5, $4.2,8,7.6,8.4,9.4,16.3$, notario 2.17 , notariu 8.22, 9.22, 15.13, 16.16, perteençias 12.6, precio 1.9(2), 3.6, 4.7(2), 5.6(2), 6.6, preçio 7.5, prior 4.15, Rrauioso 4.5, Ualderriquia 5.14, uirem 6.1, virem 7.1, uiron 1.17, uirom 2.16, etc. Pero hai bastantes casos de $j$ e $y$. A grafía $j$ podémola ver en abrjl 14.9, Agijn 5.14, 9.21, 16.15, Aguijm 3.2,4, Aguí́n 7.5,13, 13.12, 14.14, Domjnga 3.3, 15.1, Domj́ngez 10.10, 11.10, 12.12, 13.13, 15.11, Domjngo 3.13, 8.20, 9.20, Fijz 6.15, iscriuj 7.15, jno 2.9, Martj́n 4.17, 11.8,10, 12.10,12, 15.12(2), mja 16.9, mjas 16.10, mijsmo 1.8, mjn 2.5, 8.9,15(2), 9.9,14,15, precjo 6.5, Rjuu 1.7, Samartino 4.17, Sancij 15.13(2), ujrem 4.1, ujron 3.15 e inclusive en fuj 14.16 e mujtos $1.17,3.15,4.20,6.15$.

3.1.1. A grafía $y$ é moi frecuente como segundo elemento dun ditongo, como en Pay 2.14(2), 10.9, 11.9, 12.11, uay 1.6, vay 1.7, a pateyro 2.14, Carreyra 3.13 , carreyra 11.5 , canaleyro $1.15,5.15$, celareyro 4.16 , conparey 4.5 , dereytos 16.6, dereyturas 9.10, ferreyro 2.14, feuereyro 5.9, 8.2, feyta 15.7, ffrey 4.3, 6.3, 7.3, 10.3, 11.3, 12.3, 13.3, leyra 4.5, mandey 14.16, meyrino $1.13,8.18$, moesteyro 2.4 , peyte 5.8, queyra 1.10, 2.8, 3.8, 4.10, 5.8, 6.7, 7.8, 10.6, 11.6, 12.9, 13.6, 14.8, Queyroga 4.19, rey 2.10, 3.8,10, 5.8, 6.10, 7.10, 8.16, 9.16, 13.8, 14.10, 15.8, 16.10, rrey 1.11, 2.9, 4.11,13, 5.10, 12.10, 15.6,10, 16.11 , rreynando 2.10 , rreynaua $15.8,16.10$, reynos $5.10,7.10,14.10$, rigeyro 1.6, Uеyga 4.20, Uiиéyz 5.13, 6.13, Uiuéy[z] 8.21, Boys 12.7, 14.6, foy 1.4, 8.5, 
14.2, Rrogidoyro 12.8, 14.5, muytos 2.16 e Rruy 4.19. Con todo, hai que indicar que nalgúns casos aparece $i$ como segundo elemento, como en Carpenteiro 8.6, 9.6, Correicas 8.22, 9.21, dereituras 8.10, fenereiro 9.2, meirino 2.12, 3.11, 4.14, 5.12, 6.11, 7.12, 9.18, 13.9, moesteiro 8.3,5,11,12,14, 9.3,5,11,14, Moreira 16.13, mosteiro 16.4,6, pedreiro 8.7, 9.7, peite 8.13, 9.13, 15.6, preito 2.4, 4.8, 8.13, 9.13, queira 15.6, rreinaua 8.16, 9.16, Sueiro 16.12, Bois 14.3, foi 9.5 e fui 5.5. Por outra banda, a grafía $y$ aparece na forma medieval $y 7.15$ ou by 14.17 , xunto a $h i$ 8.23, 9.22, 15.14, 16.17, chega a casos de vogais en hiato, como en oýrom 2.17, 4.20 ou oýron 1.18, 3.15, 5.16, 6.16, e ocasionalmente tamén en byspo 1.12, 2.11. Ademais, é a grafía normal para a primitiva semiconsoante intervocálica en alfayat 14.15, mayor 1.13, 2.12, 3.11, 4.14, 5.12 e juyo 4.12, que alterna con juio 15.8. Desenvolvín con y a palabra moyos $16.7,8$.

3.2. Para a representación do $/ \lambda /$ alternan $l l$ e $l$. Aparece $l l$ en Abbellom 6.13, Allariz 14.13, Anllo 10.9, 11.9, 12.11, Caruallos 12.5, filla 5.2, 14.2, fillas 13.2, fillo 4.18, 14.3, fillos 3.2, 4.3, 5.5, 13.2, Jullão 10.2, muller 7.6, 10.2, 11.2, 12.2, 14.2. Aparece $l$ en alẽa 3.7, alena 2.8, melor 15.7 e muler 2.2,5, $4.2,5.5,8.6,9.6,16.3$.

3.3. Tamén alternan $l$ e $l l$ para representar $/ 1 /$, se ben é moito máis usual $l$, como vemos en alo 1.7, 2.3,6(2), 4.9, 6.3, 10.3, 11.3, 12.4, 13.3, 14.4, alos 12.5, aqueles 2.5, Bertólez 3.14, Caldelas 1.12, 2.11, 3.11, 4.14, 5.11, 6.11,12, 7.11, 8.3,17,20,22, 9.3,17,20,22, 13.9, 14.11,16, 16.16, Canpelo 1.16, capelán 1.16, 2.15-16, Castela 14.10, Castrelo 2.3, caualeyro 1.15, 5.15, Cela 14.13, celareyro 4.16, dámosuola 5.6, daquel 4.4, daquela 5.7, dárenlos 16.7-8, defendérmola 1.10, del 2.9, 3.8, 4.11, 5.8, 12.10, 15.6,10, 16.11, dela 4.9, 11.4, delo 16.8, ela 6.8, 13.7, eles 8.9, 9.9, Galiza 1.13, 2.12, 3.11, 4.15, 5.12, 6.11, 7.12 , 13.10, 14.12, mil 14.9, pela 11.5 , pelo $1.5,6$, pilitero 14.15 , prelado $1.14,15,6.14$, quales 7.5, sóbrela 5.3, ssóbrelo 14.5, tódoslos 8.2, 9.2, Ual do Nero 16.12, Ualderriquia 5.14, vila 2.4, 4.6, 7.4, Uila 12.5, 15.4 e uola 7.8, 12.8, 14.8. Casos de $l l$ en posición intervocálica aparecen en Castella 8.16, 9.16, 15.9, 16.10-11, Caldellas 15.13-14, Galliza 8.18, 9.18, 15.10, 16.12 e uolla 15.6; en posición final de palabra en mill 6.9, 13.14; en posición implosiva interna en Calldelas 15.9 e en posición inicial en lla 4.8 e llo 4.20.

3.4. Para a representación do / $\mathrm{n} /$ alternan, como é normal nos textos galegos, $n$ e $\tilde{n}$. Temos $n$ en conoçuda 1.1, 2.1, 3.1, 4.1, 6.1, 7.1, 13.1, 14.1, conuada 8.2, 9.2, 15.1, 16.1, dineros 1.17, Johanino 15.11, Marina 1.3, 3.3, 5.2,4, 6.2, 7.7, 14.2, Martino 2.13, meirino 2.12, 3.11, 4.14, 5.12, 6.11, 7.12, 9.18, 13.9, meyrino 1.13, 8.18, Muozino 10.8, 11.9, 12.11, Samartino 1.15, 8.19, 9.19, Samartino 4.17, tena 8.10, 9.10 e Uinas 15.12. Temos $\tilde{n}$ en Cañoto 13.12, coñoçencia 2.7, Mariña 8.6, 9.6, 15.2, Martiño 12.3, teña 4.8, teñamos 2.4, uiña 13.4 e Viñas 11.2. 
3.5. Consoante nasal $n$. En posición final de palabra aparece unha consoante nasal plena que se pode representar graficamente por $n, m$ ou por un trazo sobre a vogal anterior, o que levou a moitos investigadores a afirmar arbitrariamente que non existe a pronuncia /n/ e que só temos unha vogal nasal. A grafía con $n$ está en Agiín 8.21, Agij́n 9.21, 16.15, ben 1.9, 3.6, 4.7, $5.7,6.6,7.5,10.5,11.6,12.7$, 13.5, dárenlos 16.7-8, don 1.8,11, 2.10, 3.10, $4.13,5.10,14,6.10,7.6,10,13.8,14.10$, en 1.11,12,13, 2.3,4,6,7,10(2),11,12, $3.4,8,9,10(2), 11, \quad 4.4,5,6,8,11(2), 12,13(2), 14, \quad 5.8,9(2), 10,11,12, \quad 6.4,10(2), 11$, $7.8,10,12, \quad 8.4,9,10,11,13,16(3), 17,18, \quad 9.4,9,10,11,13,16(4), 18, \quad 10.4,6,7, \quad 12.5,7,9$, 13.4,8(2),9,14, 14.6,8,10(3),11,12, 15.3,4,6,7,8(2),9,10, 16.4,10(2),11(2), fiquen 2.5, Martín 1.14, 6.13, 10.8, oýron 1.18, San 16.15, un 2.2, 14.9 e uelnks ón 1.4. Con $m$ aparecen Abbellom 6.13, Aguijm 3.2,4, atem 16.8, diam 16.6, dom 16.7, fiquem 9.10, oýrom 2.17, 4.20, quem 8.13, 9.13, quitaom 14.3, tem 8.7, 9.7, uenciom 10.2, virem 3.1 e uirom 4.20. Tendo en conta a alternancia da grafía, nos casos en que aparece un trazo sobre a vogal, unhas veces transcribín a consoante nasal como $n$ e outras como $m$. Puxen $n$ en Agij́n 5.14, Aguij́n 7.5,13, 13.12, 14.14, algún 1.10, 2.7, 3.7, 4.10, 5.7, 6.7, 7.7, $10.6,11.6,12.9,13.6,14.7,15.5,16.8$, ben 15.5 , capelán 1.16, 2.15-16, con $3.2,6.2,8,7.2,6,10.2,11.2,12.2,5,13.2(2), 7,14.2,3$, cun 8.9,14,15, 9.9,14,15, $16.3,5$, don $1.12,13(2), \quad 2.11(2), 12,13(2), \quad 3.5,10,11,12, \quad 4.3,13,14,15(2)$, 5.11(2),12, 6.3,10,11(2), 7.3,11(2),12, 8.16,17(2),18, 9.16,17,18, 10.2,3,8, 11.3, 12.3, 13.3,9(2),10(2), 14.4,11(2),12, 15.8,9,10, dun 13.4, foron 1.14, 2.13, 3.12, $5.12,6.12,7.12$, 8.18, 9.18, 10.8, 11.8, 12.10, 13.10, 14.12, 16.12, forun 15.11, in 4.8,9, 12.5, Joábn 15.2, Leborín 11.4, León 8.16, 9.16, 14.10, 15.8, 16.10, Martín 10.10, 13.10,12, Martj́n 4.17, 11.8,10, 12.10,12, 15.12(2), Meén 5.15, mjn 2.5, 8.9,15(2), 9.9,14,15, oýron 3.15, 5.16, 6.16, pan 2.7, San 13.11, uençón 3.4, 4.3, 5.2, 7.2, vençón 6.2-3, uiron 1.17, 5.16, 6.15, ujron 3.15 e tamén en $d o[n]$ 9.17, 15.9. Puxen $m$ en agam 8.8, 9.8, comuem 16.6, dizem 12.8, dom 16.2,10,11,12, uenciom 11.3, 12.3, ueno $\mathrm{m} \mathrm{13.3,} \mathrm{uirem} \mathrm{1.2,} \mathrm{2.1,}$ $6.1,8.3,9.3,13.1$, virem $7.1,14.1,15.1,16.2$, ujrem 4.1, uirom 2.16 e en $f i$ que $[\mathrm{m}] 8.11$.

3.5.1. En posición interna volve darse a alternancia na representación do $/ \mathrm{n} /$, mesmo ante $p$ ou $b$, pois temos $n$ en anbos 2.5 , anparados 16.10, anparar 8.14, 9.14 e senpre 1.10, 6.8, 11.7, 13.7; $m$ en dezembro 16.1, ensembla 16.2-3, sempre 3.9, 8.8,14, 9.8,14, 16.3-4,9, así como en cemteo 16.7, comuem 16.6, damme 9.9 e demamdar 16.9. Abundan tamén outras palabras que teñen $n$, como Affonso 7.12, 16.10, Afonso 1.11,13, 2.12, 3.11, 4.14, 6.10, 8.18, 13.9, 15.10, Alfonso 13.8, 15.8, Alfonsu 8.16, 9.16,18, andados 8.2, 9.1-2, 16.1, Andreu 14.12,14, 15.10, 16.12,15, defender 8.12, 9.12, defendérmola 1.10, endelalntado 15.10, 16.11, Gona luo 1.14, presentes 2.12-13, 3.12, 4.15, 6.12, 7.12, 8.19, 9.19, 10.8, 11.8, 12.10, 13.10, 14.12, 15.10, 16.12, Sanchio 
16.13, Sancij 15.13(2), Senra 8.4, 9.4, Senrra 6.4, 10.4, teendo 9.17, vendemos 15.2 e uendemos 15.4. Por iso transcribín con $n$ casos como Affonso 14.10,11, Afonso 2.10, 3.10, 4.13, 5.10,11, 6.11, Alfonso 7.10, Andreu 3.14, 4.18, 5.2,14, 7.2,6, Anllo 10.9, 11.9, 12.11, conuento 3.5, 4.4, 6.3, Domjngo 8.20, 9.20, mandado 12.13, Méndez 16.12, Monte 1.8, 2.3,6,13, 3.5, 8.4, 9.3, 16.4,6, Ponte 16.8, Sancho 4.15,16, 5.15, etc. e tamén anpararuos 6.8, 11.7, 13.7, Canba 4.19, 6.15, 10.10, 11.10, 12.12, 13.13, Canbade 8.19, 9.19, Canpelo 1.16, conpla 6.4-5, 10.4, conpramos 7.7 e Lanpaa 4.2. Transcribín con $m$ as palabras damme 8.9, nouembrio 7.9 e setembro 2.10 .

3.6. Grafía qua-. É moi frecuente que os textos medievais utilicen a grafía latinizante qua-, que nalgunhas zonas de Galicia se pronunciaba [kwa] e na maior parte do territorio [ka]. No textos medievais pode aparece-la grafía con $c$, mais é minoritaria. Temos qu- en quaes 15.5, quales 7.5 , quanta 3.4, 4.6, 6.4, 7.4,7, 10.4, 11.4, 12.4,7, 15.2, quanto 8.12, 9.12, quantos 1.2, 2.1, 3.1, 4.1, $6.1,7.1,13.1,14.1,15.1,16.2$ e quarta 4.9. Tamén chega a aparecer en casos de [ko], como en Quoto 1.5,16 'Coto'.

3.7. Grafía con $h$. Como en latín o $h$ deixara de pronunciarse, o máis frecuente é que as palabras que a levaban nesta lingua aparezan sen ela en romance, aínda que hai casos de conservación. Nos nosos documentos falta na palabra ome 1.10,17, 2.7,15, 3.7, 4.10, 5.7, 6.7, 7.8, 10.6, 11.6, 12.9, 13.6,11, $14.7,15.6,16.9$, omes 8.2, 9.2 e alterna en herdade 1.4, 2.3, 3.4, 4.6,11, $5.2,7,9,6.4,7.4,7,8,10.4,11.4,12.4,7,9,13.6,14.5,8,15.2-3,7$ ou erdade $8.4,8(2), 14,9.4,8(2), 14,11.6$, Tamén pode aparecer en palabras que non tiñan $b$ en latín, como en hi 8.23, 9.22, 15.14, 16.17 e by 14.17 , xunto a $y 7.15$.

3.8. Cf. as grafías para $/ \mathrm{b} / \mathrm{e} / \beta /(\mathbb{S} 6.1,6.1 .1), / 3 /$ ( $(6.2 .1), / \mathrm{ts} /(\$ 6.2 .2)$, /z/ e /s/ (\$ 6.2.3).

3.9. Trazos superfluos por grafía latinizante. Algo moi usual en determinadas palabras é que, por grafía latinizante, leven frecuentemente un trazo sobreposto sen ningún valor fonético. Ocorre isto en $\overline{\text { año }} 14.9$, a $\overline{\text { noos }} 6.9$,

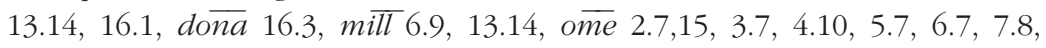
10.6, 11.6, 12.9, 13.6,11, 14.7, 15.6, 16.9 ou Sanchio 16.13, formas que alternan con outras que non levan ningún trazo, como ano 2.7, 16.7, como 1.6(2),7, 11.5, dona 2.2, mil 14.9, ome 1.10,17 e omes 8.2, 9.2.

\section{Abreviaturas}

4.1. Nos textos podemos achar abreviaturas latinizantes, como ocorre en Santisso (escrito scisso) 1.5, Santa (escrito $\overline{s c a}$ ) 5.4 ou Santiago (escrito sciago) 7.14. Polo contrario, en contra do que ocorre na maior parte dos textos medievais, que utilizan con enorme frecuencia a abreviatura $\overline{d c o}, \overline{d c a}$ para dito, 
dita, cos plurais correspondentes, nos nosos textos aparecen as formas plenas, ben coa forma latina, como en dicto 8.5, 12.8, dictos 2.5, dicta 7.6, ben coa forma galega dito 9.5,12, ben cunha forma medio romance ditu 8.11,12, 9.11, 15.3 ou cunha forma que utiliza a abreviatura ${ }^{9}$, que en latín equivale a us e que en romance se tomou para representar os, que foi a lectura que adoptei en ditos 8.11, 9.11, se ben neste caso, tendo en conta a alternancia dito / ditu do notario, tamén se podería interpretar como ditus.

4.2. Outras abreviaturas dignas de mención son a utilización da abreviatura correspondente a per co valor de pre en sempre 8.8,14, 9.8,14, 16.3-4,9, a abreviatura que corresponde a que co valor de $q u$ en $\bar{q} e=q u e 16.6$ e as formas $a \bar{n}=$ ante 6.9 e $\bar{v}=$ vnde 11.5. A abreviatura parecida a un 9 transcribina como con en 1.2, 2.2, 4.2(2), 5.2, 12.2, conparey 4.5, conpramos $7.7 \mathrm{e}$ conuento $1.8,7.3$.

4.3. Alén de todo isto, tamén é moi importante o uso de abreviaturas desaxustadas, particularidade que se dá con relativa frecuencia nos apelidos. Cando estes aparecen desenvolvidos, presentan, en xeral, a forma romance, mais cando están abreviados, adoptan moitas veces unha grafía latinizante que debe desenvolverse pola forma romance correspondente. Temos isto en $\overline{\text { iohs }}=$ Eanes 1.15, 2.14,15, 3.13,14, 4.18, 6.2,14,15, 7.13, 10.9,10, 11.9,11, 12.11,12, 13.12,13, 14.14,16, io $\overline{a h s}=$ Eanes 16.15(2) ou jo $\overline{a b s}=$ Eanes 8.6,21, 9.6,21; $\overline{u l s q z}=$ Uaásquez 10.9, 11.9-10, 12.11 ou $\overline{u l q z}=$ Uaásquez 14.12,14 e $\overline{p l z}=$ Páez 10.2, 14.15. As formas plenas romances podémolas ver en Eanes 1.12,16, 4.2,8,16, 5.15, 8.19, 9.19, Páez 4.5, 6.13, Uaásquez 1.3,5, 5.13 e Vaásquez 4.2, 8.20-21, 9.20. Respectei as formas Johane 3.5, 6.3, 7.3, 12.2-3, Iobane 13.3, Johanino 15.11 e Joáhn 15.2.

4.4. Unha dúbida preséntanola o adxectivo público, que aparece escrito de varias maneiras: $\overline{p b l i c u}$, transcrito como públicu 15.13, ppublu, transcrito como ppúblicu 16.16, e pplico, que podería considerarse grafía desaxustada e lerse público, pero que, tendo en conta que en textos latino-medievais aparece puplicus, resolvín como púplico en 14.15.

\section{Particularidades fonéticas NO VOCALISMO}

Empezarei por referirme ás alternancias que se dan entre determinadas vogais.

5.1. En primeiro lugar atopámo-la alternancia entre $e / i$ en casos en que lles corresponde normalmente $e$, particularidade que se dá con bastante frecuencia nos primeiros textos. O normal é que apareza a vogal $e$, que podemos ver, por exemplo, en derecto 4.10, 6.8, 11.7, dereituras 8.10, dereytos 
16.6, dereyturas 9.10, desto 3.6, Eanes (véxase $₫ 4.3$ ), en (véxase $₫ 3.5$ ), endeantado 14.11-12, 15.10, 16.11, eno 5.9, 8.5,7, 9.5,7, esto 1.7, 8.7, 9.7, fige 8.22, 9.22, 15.14(2), 16.16,17, Guná luez 1.18, 2.17, 3.15, 4.19,21, 5.3,16 6.16, 7.13,14, 10.11, 11.11, 12.13, 13.14, 14.7,15, Guncáluez 8.22, 9.22, 15.13, 16.16, nomeado 1.5,9, 3.6, 4.7, 5.6, 7.5, 15.5, nomẽado 6.6, 10.5, 11.5, 12.6, 13.5, 14.5, parte 1.6, Rrodrígez 5.15, 13.2,11, 14.13, se 1.10, 2.7, 3.7, 4.10, 6.7, 7.7, 10.6, 11.6, 12.8, 13.6, 14.7, 15.5, Triues 8.9,17, 9.9,17, uener 1.10, 2.7, $3.7,4.10,5.8,6.7,7.8,10.6,11.6,12.9,13.6,14.7$, vẽer 15.6. Tendo en conta isto transcribín con e Domj́ngez 15.11 e Rodrígez 14.14. Inclusive chega a aparecer $e$ por $i$ en Carpenteiro 8.6, 9.6.

5.1.1. Xunto a estes casos, hai outros nos que por latinismo ou por imprecisión se escribe $i$ en lugar de $e$, como en in 4.8,9, 12.5, inno 4.12, jno 2.9, iscriuj 7.15, iscriuío $2.17,6.16,10.10,11.11,12.13,13.13$, pilitero 14.15, rigeyro 1.6, Rodrígiz 8.21, 9.21, 15.11, 16.3, si 5.7. Algunhas outras formas con $i$ poden deberse a esta mesma circunstancia, pero posiblemente se deban ó feito de que no galego medieval é frecuente a alternancia entre as dúas vogais nalgunhas palabras. Isto pode valernos para arcidiágõo 1.12, díam 16.6, mijsmo 1.8, pugi 8.23, 9.22 e, especialmente, para escriuir 14.16 e recibimos 15.4 , que son as formas que se impuxeron no galego.

5.2. En segundo lugar témo-la alternancia $o / u$ en posición final. O normal neste caso é que apareza -o, que é a terminación normal en romance, e por iso atopamos nos nosos textos as formas Affonso 7.12, 14.10,11, 16.10, Afonso 1.11,13, 2.10,12, 3.10,11, 4.13,14, 5.10,11, 6.10,11, 8.18, 13.9, 15.10, ago 9.4, aio 4.6, 7.4, Alfonso 7.10, 13.8, 15.8, alo 1.7, 2.3,6(2), 4.9, 6.3, 10.3, 11.3, 12.4, 13.3, 14.4, Anllo 10.9, 11.9, 12.11, ano 2.7, 14.9, 16.7, ao 1.8, 3.5, 8.3, 9.3, 16.6, arcidiágõo 1.12, auoo 5.4, bispo 3.10, 4.13, 5.11, 6.10, 7.11, 13.8, 14.11, byspo 1.12, 2.11, Burgo 1.15, 2.14,16(2), 6.13, 13.12, Candaendo 6.14(2), Canpelo 1.16, Cañoto 13.12, a pateyro 2.14, capto 5.8, Carpenteiro 8.6, 9.6, Castrelo 2.3, canaleyro $1.15,5.15$, celareyro 4.16, cemteo 16.7 , clérigo 1.16, 6.15, 10.9(2),10, 11.9,10(2), 12.11(2), como 1.6(2),7, 11.5, conuento $1.8,3.5,4.4,6.3,7.3,10.3,11.3,12.4,13.3,14.4$, copto 3.8, 10.6, 12.9, 14.8, couto 8.13 , 9.13, 15.6, delo 16.8, derecto 4.10, 6.8, 11.7, desto 3.6, deuo 8.12,14, 9.11,13, dezembro 16.1, dicto 8.5, 12.8, dito 9.5,12, do 1.6,17, 2.15, 5.2, 8.2, 9.2, 13.11, 16.5,12, Domjngo 3.13, 8.20, 9.20, dublo 5.9, endeantado 14.11-12, 15.10, 16.11, eno 5.9, 8.5,7, 9.5,7, esto 1.7, 8.7, 9.7, Exertedo 1.6, faço 7.15 , ferreyro 2.14 , feuereiro 9.2, feuereyro 5.9, 8.2, fezo 14.17 , fillo 4.18, 14.3, Gonçaluo 1.14, inno 4.12, jno 2.9, Johanino 15.11, juio 15.8, Jullão 10.2, juyo 4.12, lo 6.15, llo 4.20, Loureno 13.11, maldito 2.8, mandado $10.11,11.11,12.13$, 13.13, marcio 10.7, 11.8, 13.8, marido 7.2, Martino 2.13, Martiño 12.3, meirino 2.12, 3.11, 4.14, 5.12, 6.11, 7.12, 9.18, 13.9, meyrino 
1.13, 8.18, meo 1.9, mijsmo 1.8, moesteiro 8.3,5,11,12,14, 9.3,5,11,12,14, moestero 2.3,6,7, 4.9, moesteyro 2.4, mosteiro 16.4,6, Mouro 2.15, 15.12, moro 4.4, Muozino 10.8, 11.9, 12.11, Nero 16.12, no 10.7, 11.8, nomẽado 6.6, 10.5, 11.5, 12.6, 13.5, 14.5, nomeado 1.5,9, 3.6, 4.7, 5.6, 7.5, 15.5, nosso 16.4, notario $2.17,6.16,10.11,11.12,12.13,13.14,14.7,15$, nouembrio 7.9 , outro 2.4 , 4.11, pago 1.17, pasamento 2.4-5, 8.10, 9.10, patrimonio 7.4 , pedreiro 8.7 , 9.7, pelo $1.5,6$, pilitero 14.15 , porto 1.7 , preçio $7.5,10.5$, 11.5, precio $1.9(2)$, 3.6, 4.7(2), 5.6(2), 6.6, 12.6(2),8, 13.5(2), precjo 6.5, preo 10.5, preco 15.4, preito $2.4,4.8,8.13,9.13$, prelado $1.14,15,6.14$, púplico 14.15 , quanto 8.12 , 9.12, quito 8.6, 9.6, Quoto 1.5,16, Ramo 8.4, 9.4, 16.4, Rramo 1.8, 2.3,6,13, $3.5,4.4,6.3,7.3,6,10.3,11.3,12.4,13.3,14.4$, Rrauioso 4.5, rregnando 1.11, $3.10,4.13,6.10,7.10,13.8,14.10$, rrenando 5.10, rreynando 2.10 , rigeyro 1.6 , Samartino 1.15, 8.19, 9.19, Samartino 4.17, Sanchio 16.13, Sancho 4.15,16, 5.15, Santiago 7.14, Santisso 1.5, setembro 2.10, signo 5.4, 6.5, sinno 8.23, 9.22, 16.5, sino 15.3, Sismiro 13.4, ssóbrelo 14.5, sogro 5.4 , Souto 5.2 , souto 13.4, Sueiro 16.12, teendo 8.17, 9.17, 15.9, tenendo 1.12, 2.11, 3.11, 4.14, 5.11, 6.11, 7.11, 13.9, 14.11, todo 1.7, 8.7,18, 9.7,18, Vaasco 3.12, 4.16, 5.14, $8.21,9.21,13.11,14.13,16.13$, viso 1.5 . Tamén seguido do pronome en quitoa $8.4,9.4$ e renúncoa $8.4,9.4$.

5.2.1. Por outra banda, cando temos -os en posición final hai moitos casos coa terminación propia romance, como vemos en alos 12.5, andados 8.2, 9.1-2, 16.1, anos 6.9, 13.14, 16.1, anparados 16.10, anpararuos 6.8, 11.7, 13.7, auemos 10.4, 11.4, 13.4, Caruallos 12.5, dárenlos 16.7-8, dictos 2.5, dos 1.17, fillos 3.2, 5.5, 13.2, mujtos 1.17, 3.15, 4.20, 6.15, muytos 2.16, os 8.10, 9.10, outros 1.17, 2.16, 3.14, 4.20, 5.15, 6.15, pagados 1.9, 3.6, 5.7, 15.5, quantos 1.2, 2.1, 3.1, 4.1, 6.1, 7.1, 13.1, 14.1, 15.1, 16.2, quitos 5.7, regnos 1.11 , 2.11, reynos 14.10 , todos 1.11, 2.11, 4.13, 5.10, 6.10, tódoslos 8.2, 9.2, uos 14.5,6,7. Por esta razón, cando nos manuscritos se usa a abreviatura ?, decidín transcribila por os en anbos 2.5, auemos 1.4, 2.3, 3.4, 5.3, 6.4, 12.5,7, 13.4, 15.3, auiamos 16.4, conpramos 7.7, damos 2.2, 7.6, 16.3, dámosuola 5.6, darmos 2.6, demandauamos 14.5, dereytos 16.6, dineros 1.17, ditos 8.11, 9.11, fazemos 3.3, 4.3, 5.2, 10.2, ffazemos 1.3-4, 6.2, 7.2, 11.2, 12.3, 13.2, 14.3, fillos 4.3, mandamos 14.6, outorgamos 16.3, pagados 4.7, 6.6, 7.5-6, 10.5-6, 11.6, 12.7, 13.6, Pedrouços 7.14, recibimos 15.4, regnos 3.10, $4.13,6.10,13.8$, reynos 5.10, 7.10, somos 1.9, 3.6, 5.7, 15.5, sumos 6.6, 7.5, 10.5 , 11.6, 12.7, 13.5, teñamos 2.4, todos 7.10, 13.8, 14.10, uendemos 12.8, 15.4 e vendemos $1.7,15.2$.

5.2.2. Agora ben, igual que ocorre noutros moitos textos dos primeiros tempos, é bastante frecuente que apareza a grafía con - $u$ en posición final, o que mostra a inseguridade gráfica dos escribas e a tendencia a seguir escribindo coa terminación propia do latín, mesmo cando en latín remataba en -o 
a palabra. Son os seguintes casos: agu 8.4, Alfonsu 8.16, 9.16,18, asusu 11.4,5, bispu 15.9, Вurgu 4.17, 16.8, clérigu 15.12, 16.13,14,15, desusu 8.5, 9.5, 12.8, dessusu 8.12, 9.12, Diagu 15.13, ditu 8.11,12, 9.11, 15.3, du 1.15, 2.14,16(2), 4.17, 6.13, ми́ogu 4.16-17, nоssu 1.4, 14.3, nоsu 2.6, nотаriu 8.22, 9.22, 15.13, 16.16, públicu 15.13, ppúblicu 16.16, Rjuu 1.7, Rodrigu 15.9-10 e San Gurgu 16.15. Esta tendencia latinizante tamén se dá en sumus 4.7, cun 8.9,14,15, 9.9,14,15, 16.3,5 e forun 15.11. Malia aparece-la palabra sumus, transcribín a forma abreviada como sumos (cf. \$ 5.2.1) e tamén puxen foron en $1.14,2.13,3.12,5.12,6.12,7.12$, 8.18, 9.18, 10.8, 11.8, 12.10, 13.10, 14.12, 16.12 e forom 4.15 .

5.2.3. En posición interior de palabra é normal que apareza $o$, se ben debemos facer algunhas observacións. Unha delas é que atopamos palabras que utilizan $u$ en posición tónica, normalmente por tendencia latinizante, como poden ser dublo 5.9, 7.8, Мúogu 4.16-17, sumus 4.7, sumos 6.6, 7.5, $10.5,11.6,12.7,13.5$, vnde 11.5. Outra é que en posición átona aparece $u$ por latinismo en dublada 4.11, 14.8, 15.7 e que, fronte a Gona luo 1.14, atopamos Gunçáluez 1.18, 2.17, 3.15, 4.19,21, 5.3,16, 6.16, 7.13,14, 10.11, 11.11, 12.13, 13.14, 14.7,15 e Guncáluez 8.22, 9.22, 15.13, 16.16. Unha terceira é que noutros casos a alternancia $o / u$ en posición átona interna é algo connatural á toda época medieval e por iso atopamos conoçuda 1.1, 2.1, 3.1, 4.1, 6.1, 7.1, 13.1, 14.1 e conug da 8.2, 9.2, 15.1, 16.1. Alén deste caso, noutras formas que presentan alternancia na Idade Media entre as dúas vogais, os nosos textos teñen, por unha banda, só muler 2.2,5, 4.2, 5.5, 8.6, 9.6, 16.3 ou muller 7.6, 10.2, 11.2, 12.2, 14.2, e, por outra, alternancia entre logar 1.5, 15.3,7 e lugar 1.8, 3.6, 4.4,12, 6.4, 7.4, 10.3, 11.4, 12.4, 13.4, 14.4,5.

5.2.4. Fronte á tendencia a escribir $u$ cando lle corresponde $o$, como contrapartida tamén podemos atopar palabras que levan un $o$ cando lles corresponde $u$, ben en posición final, como iscriuío $2.17,6.16,10.10,11.11,12.13$, 13.13, ben en posición interna, como scomongado 2.9 e Uermốez 3.13. Como caso contrario a iscriuí, mantén o ditongo o antropónimo Andreu en $3.14,4.18,5.2,14,7.2,6,14.12,14,15.10,16.12,15$.

5.3. Non son estas as únicas alternancias vocálicas que nos aparecen nos textos, pois aínda podemos citar algunhas máis. Así, hai alternancia entre o/e en seu 13.11, seus $6.10,7.10,13.8,14.10,16.6$ e sou 1.16,17, 6.12, sous 1.11 , 2.11, 3.10, 4.13, 5.10. Tamén alternan as preposicións per $<$ PER e por $<$ PRO, como vemos en per 1.11(2), 2.3, 6.7(2), 8.15(2), 9.14,15, 10.11, 11.7(2),11, 12.13, 13.6,7,13, 16.10 e por 1.8, 3.6, 4.6, 5.6, 6.5, 7.5,7, 8.8(3), 9.8(3), 10.5, 11.5, 12.6,8; sen embargo, na combinación co artigo só temos pela 11.5 e pelo 1.5,6. Para os meses achamos formas con o final en nouembrio 7.9, setembro 2.10 e dezembro 16.1 e unha forma medio latinizada outuber 3.9. Como antropónimo aparece Lope 1.5 . 
5.3.1. Dentro da posible alternancia entre $a / e$ aparecen, por un lado, as formas Aras 8.3,11,13, 9.3,11,13 e Diagu 15.13 e, por outro, pera 16.3 e Secar de Boys 12.7, 14.6 ou Secar de Bois 14.2-3. En hiato con e tónico permanecen as formas primitivas con $a$ en Candaendo 6.14(2) e taega 2.7. Ademais, en lugar dunha forma con $u$ na primeira sílaba, atopamos Lemeares $1.14,15.3,11,12$ e na posible alternancia $e i / i$ para o topónimo rexístrase a forma con ditongo en Queyroga 4.19. Cf. moesteiro / mosteiro no $₫ 5.7$. Digna de mención é tamén a forma Nauéoa 16.8,14 para o actual Navea.

5.4. Ditongo ou. O ditongo ou, que procede sobre todo das combinacións -au-, -alt-, -oct-, está correctamente representado na maior parte dos casos, como podemos ver en cousa 1.1, 2.1, 3.1, 4.1, 6.1, 7.1, 8.2, 9.2, 13.1, 14.1, 15.1, 16.2, dou 8.3,8,9,14, 9.3,7,9,14, Loureno 13.11, Mouca 13.5, Mouro 2.15, 15.12, Ourense 1.12, 2.11, 3.10, 4.13, 5.11, 6.10, 7.11, 8.17, 9.17, 13.8, 14.11, 15.9, 16.11, Outer Rrauioso 4.5, outorgamos 16.3, outro 2.4, 4.11, outros $1.17,2.16,3.14,4.20,5.15,6.15$, outrosi 8.6,15, 9.6,15, outuber 3.9, Pedrouços 7.14, Pousada 5.3, Souto 5.2 e souto 13.4. Xunto a estas formas debemos lembra-lo caso de couto 8.13, 9.13, 15.6 < CAUTUM, que nalgúns documentos aparece coas formas supostamente latinizantes copto 3.8, 4.11, 10.6, 12.9, 14.8 e capto 5.8. No verbo audire, que deu primeiramente como resultado ouir, os documentos galegos optaron maioritariamente pola redución a oír. Por iso temos nos textos oýrom 2.17, 4.20 e oýron 1.18, 3.15, 5.16, 6.16 .

5.5. O ditongo ei. O ditongo romance ei ten diversas orixes, pois chégase a el por evolución do grupo latino -ct-, dos sufixos -ariu, -eriu e doutros casos de "vogal $+r+$ iode", por perda de consoante intervocálica ou por analoxía. O normal desde os primeiros tempos é que o ditongo estea ben representado, coas grafías ey ou ei, como en a pateyro 2.14, Carpenteiro 8.6, 9.6, Carreyra 3.13 , carreyra 11.5 , caualeyro $1.15,5.15$, celareyro 4.16 , conparey 4.5, Correicas 8.22, 9.21, dereituras 8.10, dereytos 16.6, dereyturas 9.10, ferreyro 2.14, feuereiro 9.2, feuereyro 5.9, 8.2, feyta 15.7 , ffrey 4.3, 6.3, 7.3, 10.3, 11.3, 12.3, 13.3, leyra 4.5, mandey 14.16, meirino 2.12, 3.11, 4.14, 5.12, 6.11, 7.12, 9.18, 13.9, meyrino 1.13, 8.18, moesteiro 8.3,5,11,12,14, 9.3,5,11,14, moesteyro 2.4, Moreira 16.13, mosteiro 16.4,6, pedreiro 8.7, 9.7, peite $8.13,9.13,15.6$, peyte 5.8 , preito $2.4,4.8,8.13$, 9.13, queira 15.6, queyra 1.10, 2.8, 3.8, 4.10, 5.8, 6.7, 7.8, 10.6, 11.6, 12.9, 13.6, 14.8, Queyroga 4.19, rreinaua 8.16, 9.16, rey $2.10,3.8,10,5.8,6.10,7.10,8.16,9.16,13.8,14.10$, $15.8,16.10$, rrey $1.11,2.9,4.11,13,5.10,12.10$, 15.6,10, 16.11, rreynando 2.10 , rreynaua $15.8,16.10$, reynos $5.10,7.10,14.10$, rigeyro 1.6, Sueiro 16.12 , Ueyga 4.20, Uiuéyz 5.13, 6.13 e Uiuéy[z] 8.21. Xunto a estes casos maioritarios, atopamos unha serie de formas con outra solución gráfica, o que parece indicar que os escribas actuaban cunha tendencia latinizante ou tiñan cer- 
tas dificultades na representación do novo ditongo. Isto indícano, por un lado, formas con -ec-, como derecto 4.10, 6.8, 11.7, fecta 3.9, ffecta 2.9, 4.12, 5.9, 6.8, 7.9, 10.7, 11.8, 13.7, 14.9, pecte 2.9, 3.8, 4.11, 7.8, 10.6, 12.9, 14.8, e, por outro, formas que teñen unicamente -e-, como dineros 1.17 , moestero 2.3,6,7, 4.9, Outer Rrauioso 4.5, pilitero 14.15 e Uiuez 2.16, 9.21.

5.6. Alternancia entre os ditongos oi/ui. No textos medievais é moi frecuente a alternancia entre os ditongos oi/ui, pero nos nosos textos esta circunstancia non se produce, posto que nuns casos optouse por $u i$, como en mujtos $1.17,3.15,4.20,6.15$, muytos 2.16 ou Rruy 4.19, e noutros por oi, como en Rrogidoyro 12.8, 14.5. É normal que non haxa alternancia en Bois 14.3 ou Boys 12.7, 14.6 e tampouco se dá nas formas da $1^{\mathrm{a}}$ e $3^{\mathrm{a}}$ persoas do perfecto do verbo ser. Para a $1^{a}$ temos fuj 14.16 e, posiblemente, fui 5.5. Para a $3^{\text {a }}$ aparece foi 9.5 ou foy $1.4,8.5,14.2$. Por outro lado témo-la forma latinizante octaua 4.4. Cando as vogais están en hiato e non forman ditongo os textos distinguen entre Roínda 16.14 e iuiz 5.13, 6.12 ou juiz 8.20, 9.20.

5.7. Vogais nasais. A desaparición do -n- intervocálico latino trouxo como consecuencia a aparición en romance dunha serie de vogais nasais e nos primeiros documentos en romance os notarios teñen certas dificultades para a representación do novo son. Isto vémolo reflectido nos nosos textos, onde podemos atopar ata catro posibilidades de presentación. Hai palabras que conservan o $n$ intervocálico latino e isto pode deberse a latinismo ou a que se escribe $n$ para indica-la nasalidade da vogal. Témolo en alena 2.8, irmanas 1.2,3, Maçaneda 2.2, Menéndez 1.14, tenendo 1.12, 2.11, 3.11, 7.11, 14.11, una 2.7 e uener 1.10, 2.7, 3.7, 4.10, 5.8, 6.7, 7.8, 10.6, 11.6, 12.9, 13.6, 14.7. A forma abreviada tendo tamén a transcribín como tenendo en 4.14, $5.11,6.11,13.9$. A segunda posibilidade é que apareza a vogal cun trazo sobreposto, que é o que se impuxo, como en alẽa 3.7, arcidiágõo 1.12, bã 1.11, bõas 6.8, 8.15, 9.15, 11.7, 13.7, 16.10, dṹa 4.5, 5.2,3, 13.4, Jullão 10.2, Migếez 12.2, nomẽado 6.6, 10.5, 11.5, 12.6, 13.5, 14.5 e vẽer 15.6. A terceira posibilidade é a aparición da vogal sen ningún trazo, como en cemteo 16.7, Meén 5.15, Meend'Eanes 1.16 (escrito meẽ deanes), Meéndez 15.12, 16.2,7,13(2), moesteiro 8.3,5,11,12,14, 9.3,5,11,12,14, moestero 2.3,6,7, 4.9, moesteyro 2.4, Múogu 4.16-17, nomeado 1.5,9, 3.6, 4.7, 5.6, 7.5, 15.5, perteençias 12.6 e teendo $8.17,9.17,15.9$. Unha cuarta posibilidade pode estar na forma Candaendo 6.14 (2), actualmente Candedo, na que podemos interpretar que se representa a nasalidade da vogal co $n$ desprazado. Con todo, hai que dicir que xa desde os primeiros tempos parece que pode haber formas totalmente evoluídas, como indican Méndez 16.12, mosteiro 16.6 e posiblemente m/o]steiro 16.4. Transcribín Martíiz en 7.7.

5.7.1. No resultado do latín MĔA aparece unicamente a forma sen trazo de nasalidade: mía 2.2,5, 4.2,8, 5.2, 7.6, 8.4, 9.4, 10.2, 11.2, 12.2, 14.2, 16.3, mja 
16.9, mías 1.2, 8.15, 9.15 e mjas 16.10. Pola contra, temos nasalización e

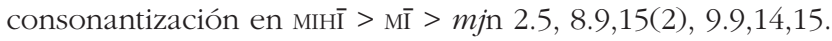

5.8. Encontro de dúas vogais iguais en hiato. Como era de esperar en textos da metade do século xiII, é moi frecuente o encontro e conservación de dúas vogais en hiato, debido á perda dunha consoante intervocálica, como ocorre en aa 1.6, 2.9, 3.8, 4.11, 5.8, 12.9, Moaas 5.5, Saas 16.5, Vaasco 3.12, 4.16, 5.14, 8.21, 9.21, 13.11, 14.13, 16.13, Uaásquez 1.3,5, 5.13, Vaásquez 4.2, 8.20-21, 9.20, Meén 5.15, Meend'Eanes 1.16, Meéndez 15.12, 16.2,7,13(2), Migếez 12.2, perteenci as 12.6, seerdes 16.9, teendo 8.17, 9.17, 15.9, vẽer 15.6, Agiín 8.21, Agijn 5.14, 9.21, 16.15, Aguijm 3.2,4, Aguij́n 7.5,13, 13.12, 14.14, Fijz 6.15, mijsmo 1.8, Sancij 15.13(2), arcidiágõo 1.12 e auoo 5.4. En lugar de oo temos uo en Múogu 4.16-17 e Muozino 10.8, 11.9, 12.11. Con todo, ocasionalmente pode haber xa crase vocálica, como en á 15.6, Méndez 16.12, Páez 4.5, 6.13 e Pay 2.14(2), 10.9, 11.9, 12.11. Tendo en conta as distintas solucións para Vaásquez e Páez, transcribín as grafías desaxustadas como Uaásquez 10.9, 11.9-10, 12.11, 14.12,14, fronte a Páez 10.2, 14.15. Como non tiña ningún outro caso para comparar, puxen Martíiz en 7.7 e morauidís en 2.9, 3.8, 4.11, 5.9, 7.9, 8.13, 9.13, 10.7, 12.10, 15.7. Cf. a conservación do -n- en irmanas, Menéndez, tenendo e uener no \5.7.

5.9. Contracción da preposición a co artigo. Como acabamos de ver, o normal nos primeiros tempos é que non se produza a asimilación da preposión $a$ á forma $a$ do artigo (cf. $a a$ no $\$ 5.8$ ) e tampouco á forma $o$ e por iso temos ao 1.8, 3.5, 8.3, 9.3, 16.6. Con todo, ocasionalmente, podemos atopar xa as formas contraídas en á 15.6 e ó 16.4. Como particularidade debo indicar a presenza da fórmula a conuento 7.3 , que corrixín para a[o] conuento, aínda que se documenta noutros textos medievais. Como arcaísmo aparece a forma alo (cf. \6.7.1).

5.10. Elisión de vogal. É moi frecuente a elisión da vogal $e$, tanto en formas nas que hoxe se segue practicando na lingua escrita coma noutras nas que actualmente se evita na lingua literaria e segue sendo usual na fala, como en da 2.8(2), 3.7(2),14, 4.4, 7.13, 8.6, 9.6, 14.4,13,14, 16.9, das 11.2, 15.11, do 1.6,17, 2.15, 5.2, 8.2, 9.2, 13.11, 16.1,5,12, du 1.15, 2.14,16(2), 4.17, 6.13, dos 1.17, del rrey / rey 2.9, 3.8, 4.11, 5.8, 12.10, 15.6,10, 16.11, dela 4.9, deste 1.9, 2.6, 4.7, 5.6, 6.6, 10.5, 12.6, 13.5, desto 3.6, desse 1.8, 3.5, 4.4, 6.4, 7.3, 10.3, 11.4, 12.4, 13.4, 14.4, daquel 4.4, daquela 5.7, dú́a 4.5, 5.2,3, 13.4, dun 13.4 ou en d'abrjl 14.9, d'Agiín 8.21, d'Agijn 9.21, 16.15, d'Aguijm 3.2, d'Aguij́n 7.5,13, 13.12, 14.14, d'Anllo 10.9, 11.9, 12.11, d'auoena $10.4 \mathrm{e}$ d'auoençia 6.4. Cf. a redución dos nomes de persoa seguidos do apelido no \$ 7.13.1.1-3.

5.11. Falta o $e$ final en alfayat 14.15 e o $e$ inicial en scomongado $2.9<$ EXCOMMUNICATU, así como en sta $5.4<$ STAT. 


\section{Particularidades fonéticas no CONSONANTismo}

Para o consonantismo indicarei as principais características dos textos.

6.1. Oposición $/ \mathrm{b} / \mathrm{-} / \mathrm{\beta} /$. Nos primeiros tempos temos unha oposición fonolóxica entre $/ b /$ - $/ \beta /$, que se mantén sistematicamente nos textos estudados e o único destacable é a representación de cada un dos fonemas. Para /b/ temos, en xeral, a grafía $b$, como en abade 1.7,17, 2.15, 3.5, 4.3, 7.3, 10.3, 11.3, 12.4, 13.3, abrjl 14.9, anbos 2.5, ben 1.9, 3.6, 4.7, 5.7, 6.6, 7.5, 10.5, 11.6, 12.7, 13.5, 15.5, Bertólez 3.14, bispo 3.10, 4.13, 5.11, 6.10, 7.11, 13.8, 14.11, bispu 15.9, bõa 1.11, bã s 6.8, 8.15, 9.15, 11.7, 13.7, 16.10, Bois 14.3, Bolmente 10.9, 11.10, 12.12, Boys 12.7, 14.6, britar 1.10, 2.8, 3.8, 4.10, 5.8, 6.7, 8.13, 9.13, 10.6, Burgo 1.15, 2.14,16(2), 6.13, 13.12, Вurgu 4.17, 16.8, byspo 1.12, 2.11, Cabras 1.7, Canba 4.19, 6.15, 10.10, 11.10, 12.12, 13.13, Canbade 8.19, 9.19, dezembro 16.1, dublada 4.11, 14.8, 15.7, dublo 5.9, 7.8, Leborín 11.4, nouembrio 7.9, recibimos 15.4, saber 16.6, sóbrela 5.3 e ssóbrelo 14.5. Tamén en públicu 15.13 e ppúblicu 16.16, xunto ó falso latinismo púplico 14.15. Con dobre consoante temos por latinismo abbade 6.3, $14.4 \mathrm{e}$ por falsa latinización Abbellom 6.13.

6.1.1. Para $/ \beta /$ domina totalmente a grafía $u$ en calquera posición: anpararuos 6.8, 11.7, 13.7, auemos 1.4, 2.3, 3.4, 5.3, 6.4, 10.4, 11.4, 12.5,7, 13.4(2), 15.3, auiamos 16.4, auoeng 10.4, auoenç a 6.4, auoo 5.4, Caruallos 12.5 , caualeyro $1.15,5.15$, comuem 16.6, conuento $1.8,3.5,4.4,6.3,7.3$, 10.3, 11.3, 12.4, 13.3, 14.4, Coua 7.13, dámosuola 5.6, demandauamos 14.5, deuo 8.12,14, 9.11,13, Eluira 2.2, 12.2, 16.3, escriuir 14.16, fenereiro 9.2, feuereyro 5.9, 8.2, Gonçaluo 1.14, Gunạa luez 1.18, 2.17, 3.15, 4.19,21, 5.3,16, 6.16, 7.13,14, 10.11, 11.11, 12.13, 13.14, 14.7,15, Guncáluez 8.22, 9.22, 15.13, 16.16, іsсriuí $2.17,6.16,10.10,11.11,12.13,13.13$, iscriuj 7.15, Nauéoa 16.8,14, Nona 14.14, nouembrio 7.9, octana 4.4, Rrauioso 4.5, rreinana 8.16 , 9.16, rreynaua 15.8, 16.10, Rjuu 1.7, Saluador 4.19, 5.14, 15.3, Triues 8.9,17, 9.9,17, Uaásquez 1.3,5, 5.13, 10.9, 11.9-10, 12.11, 14.12,14, Ual 16.12, Ualderriquia 5.14, uay 1.6, uenciom 10.2, 11.3, 12.3, ueno m 13.3, uenó n 1.4, 3.4, 4.3, 5.2, 7.2, uendemos 12.8, 15.4, uener 1.10, 2.7, 3.7, 4.10, 5.8, 6.7, 7.8, 10.6, 11.6, 12.9, 13.6, 14.7, Uermốez 3.13, Ueyga 4.20, Uila 12.5, 15.4, Uinas 15.12, uiña 13.4, uirem 1.2, 2.1, 6.1, 8.3, 9.3, 13.1, ujrem 4.1, uirom 2.16, 4.20, uiron $1.17,5.16,6.15$, ujron 3.15, Uiиéyz 5.13, 6.13, 8.21, Uiиez 2.16, 9.21, uola 7.8, 12.8, 14.8, uolla 15.6, uós 1.7, 3.5, 4.3, 5.4, 6.3, 7.3, 8.16, 9.15, $10.2,11.3,12.3,13.3,14.3,15.2,4(2)$, uos 8.14, 9.14, 14.5,6,7 e uoz 2.9, 3.8, 12.9, 15.6. En moitos menos casos os escribas usan a grafía $v$, que só está en vay 1.7, Vaasco 3.12, 4.16, 5.14, 8.21, 9.21, 13.11, 14.13, 16.13, Vaásquez 4.2, 8.20-21, 9.20, vẽer 15.6, venó n 6.2-3, vendemos 1.7, 15.2, vila 2.4, 4.6, 7.4, 
Viñas 11.2, virem 3.1, 7.1, 14.1, 15.1, 16.2, viso 1.5, vós 8.15, 9.15, 15.7, 16.9, vos 16.9 e voz 4.11, 5.8.

6.2. As sibilantes. Nas sibilantes, en xeral, mantense o sistema primitivo de xordas e sonoras, como é normal en textos do século XIII.

6.2.1. Este é caso da parella $/ \mathrm{J} / \mathrm{-} / 3 /$. Para a xorda $/ \mathrm{J} /$ só temos Exertedo 1.6 e Pixota 5.15. Para a sonora /3/ alternan as grafías $i$ e $j$ ante $a, o, u$, como en aio 4.6, 7.4, ia 2.5(2), 4.9, 5.7, 7.6, iaz 4.5, Iohane 4.3, 13.3, iuiz 5.13, 6.12, seia 1.2, 2.1,8, 3.1,8, 6.1, 7.1,9, 13.1, 14.1,6; ja 8.11(2), 9.11(2), Joábn 15.2, Johán 1.8,12,15(2),16(2), 2.11,15(2), 3.10-11,12,14, 4.14,16,17,18, $5.1,3,5,11,13,6.11,15,7.11,8.17,19(2), 9.17,19(2), 10.3,9,10,11.2,3,10,11$, 12.3,12(2), 13.9,13, 14.3,4,11,13,14,16, 15.9, 16.11,14,15, Johane 3.5, 6.3, 7.3, 12.2-3, Johanino 15.11, juio 15.8, juiz 8.20, 9.20, Jullão 10.2 e juyo 4.12. Rompen esta norma unhas cantas formas típicas da época dos inicios da escrita en romance que presentan a grafía $g$ ante estas vogais, como son agam 8.8, 9.8, ago 9.4, agu 8.4, San Gurgu 16.15 e sega 8.2, 9.2, 15.1, 16.2. Ante $e$, $i$ é normal a grafía con $g$, que vemos en fige 8.22, 9.22, 15.14(2), 16.16,17, monge 2.13,13-14, 5.15, pugi 8.23, 9.22 e Rrogidoyro 12.8, 14.5. A única forma que presenta unha evolución diferente é sea 4.1.

6.2.2. Igual ocorre na parella/dz/ - /ts/. A sonora /dz/ aparece sempre representada por $z$ : dezembro 16.1 , dizem 12.8, fazemos 3.3, 4.3, 5.2, 10.2, ffazemos 1.3-4, 6.2, 7.2, 11.2, 12.3, 13.2, 14.3, fazia 8.5,7, 9.5,7, fezo 14.17, Galiza 1.13, 2.12, 3.11, 4.15, 5.12, 6.11, 7.12, 13.10, 14.12, Galliza 8.18, 9.18, 15.10, 16.12, Muozino 10.8, 11.9, 12.11. A xorda /ts/ represéntase de diversas maneiras segundo a vogal á que se une e a posición dentro da palabra. Ante a, o, u é normal a grafía ç: auoeng 10.4, a pateyro 2.14, conog da 1.1, 2.1, 3.1, 4.1, 6.1, 7.1, 13.1, 14.1, conug da 8.2, 9.2, 15.1, 16.1, fag 14.7, fao 7.15, Gonçaluo 1.14, Gunçáluez 1.18, 2.17, 3.15, 4.19,21, 5.3,16, 6.16, 7.13,14, 10.11, 11.11, 12.13, 13.14, 14.7,15, Lanpag 4.2, Loureno 13.11, Maçaneda 2.2, Pedrouços 7.14, preço 10.5, quitaçom 14.3, Roa 2.15, uençom 13.3, uelnçlón 1.4, uenó n 3.4, 4.3, 5.2, 7.2 e venó n 6.2-3. Pero tamén pode haber casos da grafía $c$ ante estas vogais, como en Correicas 8.22, 9.21, Guncáluez 8.22, 9.22, 15.13, 16.16, renúncoa 8.4, 9.4 e preco 15.4. Ante $e, i$ alternan as grafías $c$ e $c$, se ben é máis frecuente a segunda: auoenç $a$ 6.4, coñoçencia 2.7 , perteençias 12.6 , preç o 7.5, 10.5, 11.5, arcidiágõo 1.12, Cela 14.13, celareyro 4.16, cemteo 16.7, Cide 8.19, 9.19, Cima 12.5, 15.3, García 1.13, 2.12, 3.12, 4.15,17,20, 5.12, 6.12, 7.12, 8.18, 13.10, 14.2,3, marcias 6.9, marcio 10.7, 11.8, 13.8, precio 1.9(2), 3.6, 4.7(2), 5.6(2), 6.6, 12.6(2),8, 13.5(2), precjo 6.5, recibimos 15.4, Sancij 15.13(2) e uenciom 10.2, $11.3,12.3$. Por iso transcribín García en 16.13(2). Un caso especial é $c h$ en Garchía 9.18. En posición final de palabra é normal a grafía $z$ para a xorda: Allariz 14.13, Bertólez 3.14, Díaz 3.11, 4.14, 5.11, 6.11, 7.11, 8.17,20, 9.17,20, 
10.10, 11.11, 12.12, 13.9, 14.2,13, 15.9, 16.11, Domj́ngez 10.10, 11.10, 12.12, 13.13, 15.11, Fernández 2.14, 3.2,3(3), 4.18, 5.5,6, 7.13,14, Ferrnández 15.12, 16.14, fez 1.17,18, 5.3, Fijz 6.15, iaz 4.5, iuiz 5.13, 6.12, juíz 8.20, 9.20, López 1.2,3(2),15, Martiiz 7.7, Meéndez 15.12, 16.2,7,13(2), Méndez 16.12, Menéndez 1.14, Migếez 12.2, Páez 4.5, 6.13, 10.2, 14.15, paz 2.6, 4.8, 8.11, 9.11, Pérez 2.2, 3.14, 4.16, 5.5,13,14(2), 6.12,14, 7.2,4, 8.3,7,12,13-14,20, $9.3,7,11,13,20,11.2,13.11,12,14.2,15.2(2), 12$, Rodrígez 5.15, 11.2, 13.2,11, 14.13,14, Rodrígiz 8.21, 9.21, 15.11, 16.3, Sánchez 12.2, Uaásquez 1.3,5, 5.13, 10.9, 11.9-10, 12.11, 14.12,14, Vaásquez 4.2, 8.20-21, 9.20, Uermốez 3.13, Uіие́yz 5.13, 6.13, Uіиеz 2.16, 9.21, иоz 2.9, 3.8, 12.10, 15.6 е vоz 4.11, 5.8 .

6.2.2.1. De todos estes casos citados para /ts/ en posición interna destacan unhas cantas palabras polo seu carácter arcaico. O normal é que os grupos latinos "-c + iode-" e "-t + iode-", de non evoluíren á sonora /dz/ como no citado Galiza, Galliza, teñan como resultado a xorda /ts/, coa absorción do iode pola consoante ao producirse a palatalización. Por iso temos como formas propias auoença, faç, faço, Lampag , Loureno , Mağ neda, preo , preco, quitaçom, renúncoa, Roça, uenom, uelnķón, uenón e venón, citadas no parágrafo anterior. O que pasa é que, ao lado destas formas, aparecen outras nas que se conserva a vogal $i$ por arcaísmo e proximidade ó latín, como son auoençia 6.4, coñoçencia 2.7, marcias 6.9, marcio 10.7, 11.8, 13.8, perteençias 12.6, preci o $7.5,10.5,11.5$, precio $1.9(2), 3.6,4.7(2), 5.6(2)$, 6.6, 12.6(2),8, 13.5(2), precjo 6.5 e uenciom 10.2, 11.3, 12.3.

6.2.3. Algo diferente ás outras dúas oposicións anteriores ocorre na oposición /s's - /źl, que só se produce en posición intervocálica, pois neste caso é frecuente que se rompa a norma escrita, cousa común a outros textos. Para a sonora /z/ temos normalmente a grafía $s$, como en asusu 11.4,5, casa 5.3, casar 2.2,6, 4.4, 8.5,7, 9.5,7, 16.9, casares 2.5, 8.9,11,15, 9.9,11,15, cousa 1.1, 2.1, 3.1, 4.1, 6.1, 7.1, 8.2, 9.2, 13.1, 14.1, 15.1, 16.2, деssusu 8.12, 9.12, desusu 8.5, 9.5, 12.8, Pousada 5.3, presente 14.16, presentes 1.14, 2.12-13, 3.12 , 4.15, 5.12, 6.12, 7.12, 8.19, 9.19, 10.8, 11.8, 12.10, 13.10, 14.12, 15.10, 16.12, quiser 16.9, Rrasa 3.14, Rrauioso 4.5, viso 1.5 e Teresa 13.2. Esta norma só se rompe unha vez na forma cassar 16.4. Máis variedade témola para a xorda /s/, pois algúns escribas usan indistintamente ss ou $s$. Esta alternancia vémola en assi 11.5, desse 1.8, 3.5, 4.4, 6.4, 7.3, 10.3, 11.4, 12.4, 13.4, 14.4, dessusu 8.12, 9.12, essa 2.4, 4.6, esse 8.5,11,12,14, nossa 3.7, nossas 6.8, 7.7, 11.7, 13.7, nosso 16.4, nossu 1.4, 14.3, Santisso 1.5 e asusu 11.4,5, desusu 8.5, 9.5, 12.8, ese 9.4,11,12,14, nosa 1.11, 2.8, nosu 2.6, outrosí 8.6,15, 9.6,15, pasamento 2.4-5, 8.10, 9.10.

6.3. Evolución de -n- intervocálico. Xa indiquei ó falar das vogais nasais ( $\$ 5.7$; cf. $\ 3.5)$ que o -n- desaparece no paso do latín ó romance deixando nasalizada a vogal anterior, pero esta norma rómpese cando ó -n- segue en 
posición final un -e, posto que neste caso cae o $e$ final moi cedo e permanece a consoante nasal. Por iso nos nosos textos temos Abbellom 6.13, ben 1.9, 3.6, 4.7, 5.7, 6.6, 7.5, 10.5, 11.6, 12.7, 13.5, 15.5, comuem 16.6, León 8.16, 9.16, 14.10, 15.8, 16.10, pan 2.7, quitaom 14.3, tem 8.7, 9.7, uenciom 10.2, 11.3, 12.3, uençom 13.3, ue[nç]ón 1.4, uenó n 3.4, 4.3, 5.2, 7.2 e venó n 6.23. Tamén desaparece a vogal e mantense a consoante en palabras que en latín eran proparoxítonas, como en Domjnga 3.3, 15.1, Domjngo 3.13, 8.20, 9.20, etc., monge 2.13,13-14, 5.15, Senra 8.4, 9.4 e Senrra 6.4, 10.4, ou en palabras que tiñan varias vogais átonas antes da tónica, como en scomongado 2.9. Ademais, queda en posición final un $n$ cando desaparece o $o$ final nos nomes que van seguidos do apelido, como en Martín 1.14, 6.13, 10.8,10, 13.10,12 ou Martín 4.17, 11.8,10, 12.10,12, 15.12(2), no posible occitanismo capelán 1.16, 2.15-16 e en formas reducidas que preceden a un substantivo, como Meén 5.15 e San 13.11, 16.15. Tamén desaparece a vogal final -o no derivado de ūNu, especialmente cando é numeral, como en dun 13.4, un 2.2, 14.9 e no composto algún 1.10, 2.7, 3.7, 4.10, 5.7, 6.7, 7.7, 10.6, 11.6, $12.9,13.6,14.7,15.5,16.8$, que aparece en lugar de algũu cando vai seguido dun substantivo.

6.4. O grupo latino -nn- simplifica e por iso temos ano 2.7, 14.9, $16.7 \mathrm{e}$ anos 6.9, 13.14, 16.1, igual có grupo secundario -mn-, que deu o resultado $n$ en dona 2.2, 16.3. Na forma masculina este grupo perde a vogal final cando é forma de tratamento que precede ó substantivo, como vemos en dom 16.7, don 1.8,11,12,13(2), 2.10,11(2),12,13(2), 3.5,10(2),11,12, 4.3,13(2),14,15(2), $5.10,11(2), 12,14, \quad 6.3,10(2), 11(2), \quad 7.3,6,10,11(2), 12, \quad 8.16,17(2), 18, \quad 9.16,17,18$, $10.2,3,8,11.3,12.3,13.3,8,9(2), 10(2), 14.4,10,11(2), 12,15.8,9,10$ e $d o[n] 9.17$, 15.9. No derivado de JoHANnes temos Iohane 4.3, 13.3, Johane 3.5, 6.3, 7.3, 12.2-3 e Johanino 15.11, xunto a Joáhn 15.2 e a forma abreviada que interpretei como Johán en 1.8,12,15(2),16(2), 2.11,15(2), 3.10-11,12,14, 4.14,16,17,18, $5.1,3,5,11,13,6.11,15,7.11,8.17,19(2), 9.17,19(2), 10.3,9,10,11.2,3,10,11$, $12.3,12(2), 13.9,13,14.3,4,11,13,14,16,15.9,16.11,14,15$, na que desapareceu o -e final, igual ca nos casos da terminación -ne latina. Tamén temos como resultado $n$ no apelido Eanes 1.12,16, 4.2,8,16, 5.15, 8.19, 9.19.

6.5. O -1- intervocálico latino ou doutra procedencia desapareceu no galego, como vemos en auoeng 10.4, auoenç a 6.4, auoo 5.4, endeantado 14.11-12, 15.10, 16.11, San Fijz 6.15, Mámola] 1.6, Migếez 12.2, Páez 4.5, 6.13, Pay 2.14(2), 10.9, 11.9, 12.11, Saas 16.5, taega 2.7, Vaasco 3.12, 4.16, 5.14, 8.21, 9.21, 13.11, 14.13, 16.13, Uaásquez 1.3,5, 5.13 e Vaásquez 4.2, 8.20-21, 9.20. O -1- consérvase cando se produciu a perda dunha vogal, como en algún 1.10, 2.7, 3.7, 4.10, 5.7, 6.7, 7.7, 10.6, 11.6, 12.9, 13.6, 14.7, 15.5, 16.8, Eluira 2.2, 12.2, 16.3, maldito 2.8, sinal 7.15, 14.16, 15.14, 16.16 e na forma mediolatina Michel 16.14. Hai disimilación $l>r$ e conservación da 
Consoante en LOCALE > logar 1.5, 15.3,7 e lugar 1.8, 3.6, 4.4,12, 6.4, 7.4, 10.3, $11.4,12.4,13.4,14.4,5$. Un caso particular é a conservación por latinismo en quales 7.5, fronte ó normal quaes 15.5. Tamén se conserva na palabra eclesiástica prelado 1.14,15, 6.14 e no apelido Bertólez 3.14.

6.6. En palabras que teñen grupos consonánticos con $l$ mantense o grupo nos cultismos clérigo 1.16, 6.15, 10.9(2),10, 11.9,10(2), 12.11(2), clérigu 15.12, 16.13,14,15, dublada 4.11, 14.8, 15.7, dublo 5.9, 7.8, públicu 15.13 e ppúblicu 16.16, así como no galicismo ensembla 16.2-3. Prodúcese rotacismo en preito 2.4, 4.8, 8.13, 9.13 e Tegra 5.4. O caso contrario de mudanza $r>l$ está en conpla (subst. 'compra') 6.4-5, 10.4.

6.7. A xeminada -11- deu como resultado $l$ en romance, como podemos ver en aqueles 2.5, Caldelas 1.12, 2.11, 3.11, 4.14, 5.11, 6.11,12, 7.11, 8.3,17,20,22, 9.3,17,20,22, 13.9, 14.11,16, 16.16, Canpelo 1.16, capelán 1.16, 2.15-16, Castela 14.10, Castrelo 2.3, canaleyro 1.15, 5.15, Cela 14.13, celareyro 4.16, daquela 5.7, dela 4.9, ela 6.8, 13.7, eles 8.9, 9.9, Galiza 1.13, 2.12, $3.11,4.15,5.12,6.11,7.12,13.10,14.12$, pilitero 14.15 , vila 2.4 , 4.6, 7.4 e $\mathrm{Ui}$ la 12.5, 15.4. Por tradición latina pode haber algún caso coa grafía -11-, como en Castella 8.16, 9.16, 15.9, 16.10-11, Caldellas 15.13-14 e Galliza 8.18, 9.18, 15.10, 16.12. O resultado $l$ pode, ademais, aparecer en posición final debido á perda da vogal $e$ final, como en daquel 4.4, del 2.9, 3.8, 4.11, 5.8, 12.10, 15.6,10, 16.11, Ual do Nero 16.12, Ualderriquia 5.14 e en mil 14.9, que alterna con mill 6.9, 13.14 .

6.7.1. As formas latinas ILLA, ILLu do artigo e do pronome deron como resultado primeiramente ela, elo, despois pasaron a la, lo e finalmente simplificaron en $a$, o. Por iso temos para o artigo as formas $a$ en 2.9, 3.8,9, 4.11,12, $5.9(2), 6.8,7.8,9,8.5,9.5,10.7,11.8,13.7,14.8,9,15.7,16.8$ e $o$ en 8.7, 9.7, 16.4; para o pronome $a$ en $1.18,2.17,8.22,9.22,14.16$, quitoa 8.4, 9.4, renú coa 8.4, 9.4, o en 1.17(2), 2.16(2), 3.15, 5.15, 8.8, 9.8, 15.4 e os 8.10, 9.10. Os artigos $a$, o únense á preposición $a$ nas combinacións aa 1.6, 2.9, 3.8, $4.11,5.8,12.9$ e ao $1.8,3.5,8.3,9.3,16.6$ e nas formas contraídas á 15.6 e ó 16.4. Particularidade importante é que por arcaísmo se produce a combinación da preposición a coa forma lo do artigo en alo + subst. 1.7, 2.3,6(2), 4.9, $6.3,10.3,11.3,12.4,13.3,14.4$ e alos 12.5 e que tamén aparece a forma el para o artigo en el moesteyro 2.4, a el conuento 4.4. Ademais, para o pronome pode aparece-la forma primitiva con $l$-, como en que lo uiron 6.15, la iscriuj 7.15, la iscriuio 6.16, 10.10, 11.11, 12.13, 13.13, e mesmo con $l l-$, como en que lla teña 4.8 e que llo uirom 4.20. Para o obxecto indirecto atopámo-la forma primitiva les 'lles' en 8.8,9, 9.7,8. Cf. a conservación das formas lo, la en asimilacións no $₫ 6.11$.

6.8. Grupo -d + iode-. O resultado normal en romance é $>/ 3 /$, como vemos en sei[a] 1.2, seia 2.1,8, 3.1,8, 6.1, 7.1,9, 13.1, 14.1,6, que aparece coa 
grafía g en sega 8.2, 9.2, 15.1, 16.2. Outra posibilidade de evolución é o paso á semiconsoante $y$ e a desaparición, como en sea 4.1 e meo $1.9<$ MEDIU. Para o derivado de MODIu desenvolvín a abreviatura como moyos en 16.7,8.

6.9. Grupo - $n+$ iode-. O resultado máis normal en romance do grupo -n + iode- é a palatal / $\mathrm{n} /$, como en tena 8.10, 9.10, teña 4.8, teñamos 2.4 , uiña 13.4, Uinas 15.12 e Viñas 11.2. Pero no derivado de Juniu, en lugar da forma juño, chegouse a un resultado coa semiconsoante -y-, moi típico dalgunhas palabras do galego medieval, e isto vémolo en juyo 4.12 e juio 15.8, se ben debemos chama-la atención sobre esta forma, posto que a este mesmo resultado se pode chegar desde o latín Juliu e na maior parte dos casos o texto non nos indica de cal dos meses se trata. Como cultismo aparece patrimonio 7.4 .

6.10. Grupo -gn-. O grupo -gn- latino ten varias posibilidades de evolución. A máis propia é o resultado /n/, que aparece en coñoçencia 2.7, conoçuda 1.1, 2.1, 3.1, 4.1, 6.1, 7.1, 13.1, 14.1 e conua da 8.2, 9.2, 15.1, 16.1. Por latinismo poden aparecer formas co grupo conservado, como rregnando $1.11,3.10,4.13,6.10,7.10,13.8,14.10$, regnos 1.11, 2.11, 3.10, 4.13, 6.10, 13.8 e signo 5.4, 6.5. Unha segunda posibilidade é a asimilación $g n>n n$, como en sinno 8.23, 9.22, 16.5, e a redución a $n$, como en rrenando 5.10, sinal $7.15,14.16,15.14,16.16$ e sino 15.3. Finalmente, por influencia de rei, aparecen analoxicamente formas co ditongo ei seguido de $n$ en rreinaua 8.16, 9.16, rreynaua 15.8, 16.10, rreynando 2.10 e reynos 5.10, 7.10, 14.10.

6.11. Asimilacións. As asimilacións que achamos son de varias clases. Unha delas é a de $r+l>l l>l$, que se dá en pela 11.5 , pelo $1.5,6$, sóbrela 5.3 e ssóbrelo 14.5. Outra é a de $s+l>l l>l$, para a que atopamos nos textos as tres posibilidades: a solución final en dámosuola 5.6, uola 7.8, 12.8, 14.8, defendérmola 1.10, dela 11.4 e delo 16.8; a intermedia, coa consoante xeminada, en uolla 15.6 e a primitiva, aínda sen asimilación, en tódoslos omes 8.2, 9.2. Tamén no caso da asimilación de $n+l>n n>n$ podemos atopa-la forma xa simplicada en eno 5.9, 8.5,7, 9.5,7 e jno 2.9, xunto á xeminada en inno 4.12 e a solución primitiva sen asimilación en dárenlos 16.7-8, alén da redución eno $>$ no en 10.7, 11.8. Outra asimilación diferente prodúcese no grupo $n m>m$, como vemos en Samartino 1.15, 8.19, 9.19 e Samartino 4.17. Fronte a estes casos citados debemos lembrar que non se produce asimilación nas combinacións en essa vila 2.4, 4.6 e en outro tal lugar 4.11-12.

6.12. Grafía e fonética na carta partida por abc. Como acabamos de ver, a variedade gráfica e fonética nestes textos é frecuente e o mesmo escriba pode decantarse por diversas solucións. Como unha boa mostra desta situación porei a continuación as variantes que atopamos nunha carta escrita dúas veces pola mesma man, posto que se trata dunha carta das chamadas "partidas por abc". Son as seguintes. 


$\begin{array}{ll}\text { feuereyro } 8.2 & \text { feuereiro } 9.2 \\ \text { agu } 8.4 & \text { ago } 9.4 \\ \text { esse } 8.5 & \text { ese } 9.4 \\ \text { dicto } 8.5 & \text { dito } 9.5 \\ \text { foy } 8.5 & \text { foi } 9.5 \\ \text { damme } 8.9 & \text { damme } 9.9 \\ \text { dereituras } 8.10 & \text { dereyturas } 9.10 \\ \text { fique } 8.11 & \text { fiquem } 9.10 \\ \text { a esse moesteiro } 8.12 & \text { ase moestio } 9.12 \\ \text { ditu } 8.12 & \text { dito } 9.12 \\ \text { esse } 8.14 & \text { ese } 9.14 \\ \text { Afonso } 8.18 & \text { Alfonsu } 9.18 \\ \text { meyrino } 8.18 & \text { meirino } 9.18 \\ \text { García } 8.18 & \text { Garchía } 9.18 \\ \text { Uiuey } 8.21 & \text { Uiuez } 8.21 \\ \text { d'Agín } 8.21 & \text { d'Agín } 8.21\end{array}$

\section{PARTICULARIDADES MORFOSINTÁCTICAS}

7.1. Demostrativos. Nos primeiros tempos non estaban totalmente delimitadas as funcións das distintas formas do demostrativo e do artigo. De aí que poidamos atopar fórmulas como "fazemos carta de uençón a uós ... da octaua daquel casar en que eu moro" 4.3,4, "damos un casar ... alo moestero ... per tal preito que teñamos nós outro que á el moesteyro en essa vila; e a pasamento de mjn et de mía muler ia dita fiquen aqueles casares anbos ia dictos alo moestero de M. de R. en paz; et darmos deste nosu casar alo moestero una taega de pan" 2.2-7, "fazemos carta de uençón dứa herdade que auemos ... et deste precio somos ben pagados et nós quitos daquela herdade ia dita" 5.2-3,6-7.

7.2. O artigo e a expresión da posesividade. Na época medieval para a expresión da posesividade hai tres opcións: o uso do artigo con valor posesivo, o uso do posesivo sen artigo e o uso do posesivo precedido do artigo. Por iso nos nosos documentos hai moitos casos do uso do posesivo sen artigo. Isto é normal cos nomes de parentesco, como en "que foy de nossu padre" 1.4, "con meu marido don Andreu" 7.2, "eu, Sancha López, con mías irmanas" 1.2, "con mía filla Marina" 5.2, "con nossu fillo" 14.3, "con meus fillos" 3.2, "con meus fillos e con mías fillas" 13.2, "ego, don Jullão, con mía muller María Páez" 10.1-2 e noutros en que está "con mía muller" 7.6, 11.2, 14.2, "cun mía muler" 16.3 ou "con mía muler / muller ... et con meus fillos" 4.2-3, 12.2 e tamén "et de súa muler" 8.6, 9.6 ou "a pasamento de mjn et de 
mía muler" 2.4-5. Outra expresión en que falta o artigo é "et meu sinno hi pugi" 8.22-23, 9.22, "et meu sinal y faço" 7.15, "et meu sinal hy fezo" 14.1617 , "e / et meu sinal hi fige" $15.14,16.16-17$. Un caso especial típico medieval é o uso do posesivo seguido dun xiro analítico coa preposición de, como en "Meend'Eanes, sou ome do abade" 1.16-17, que alterna con "Johán Mouro, ome do abade" 2.15 ou "Domingo Pérez, seu ome" 13.11.

7.2.1. Tamén falta o artigo noutros casos. Un deles é cando o posesivo vai precedido de preposición (xa citei algúns casos no parágrafo anterior), como "por nossas almas" 7.7, "per nosa bõa" 1.11, "per nossas bõas" 6.7-8, 11.7, 13.7, "per mj́as bõas" 16.10, "en meus días" 4.8, 8.10, 9.10, "in meus días" 4.9, "a mía morte" 4.8 ou "a meu pasamento" 8.10, 9.10. Outro caso é cando o posesivo vai precedido do cuantificador todo, estea ou non precedido de preposición, como en "dou ... toda mía erdade que agu / ago en Senra" 8.3,4, 9.3,4, "cun todas súas dereituras / dereyturas" 8.9-10, 9.9-10, "cun todos seus dereytos" 16.5-6, "con todas súas perteençias" 12.5-6, "rregnando rrey don Afonso en todos sous regnos” 1.11-12; fórmula idéntica en 2.10-11, $3.10,4.13,5.10,6.10,7.10,13.8$ e 14.10 .

7.2.2. Os casos en que aparece o artigo acompañando ó posesivo son unicamente "se algún ome uener, quer da nosa parte quer da alena" 2.7-8, "quer da nossa parte quer da alẽa" 3.7, "se algún ome da mj́a parte" 16.8-9 e "damos ... o nosso cassar" 16.3,4.

7.2.3. Outra construción medieval é o uso dun pronome persoal precedido da preposición de en lugar do posesivo, como en "e a pasamento de min et de mía muler ia dita fiquen aqueles casares anbos ia dictos alo moestero de M. de R. en paz" 2.4-6. Esta construción alterna co uso do posesivo, como en "e a meu pasamento" 8.10, 9.10 e outros exemplos.

7.2.4. O artigo pode faltar noutros casos nos que non hai referencia á posesividade, como en "en era $\mathrm{M}^{\mathrm{a}}$..." 2.10, 3.9, 4.12, 5.9-10, 10.7; "en era de mill..." 13.14, "a uós ... e a fillos de Johán Fernández" 5.4,5-6, "por preçio nomeado, LX ssoldos, de quales nós sumus ben pagados" 7.5-6; "XXXX ${ }^{\text {ta }} \mathrm{V}$ ssoldos, de quaes nós somos ben pagados" 15.5, "ffazemos carta de ue[nçón de herdade que auemos" 1.4, "rregnando rrey / rey don Afonso / Alfonso / Affonso" 1.11, 3.10, 4.13, 6.10, 7.10, 13.8, 14.10, "rrenando rrey don Afonso" 5.10, "rreynando rey don Afonso" 2.10, "rreinaua rey don Alfonsu" 8.16, 9.16 ou "rreynaua rey don Alfonso / dom Affonso" 15.8, 16.10.

7.3. O pronome persoal.

7.3.1. Colocación dos clíticos: Nas oracións subordinadas precede ó verbo, como en "que $a$ fige" 8.22, 9.22, "que $a$ fez" 1.18, "que $a$ iscriuío" 2.17, "que presente fuj e $a$ mandey escriuir" 14.16, "que la iscriuj́" 7.14-15, "que la iscriuío" $10.10,11.11,12.12-13,13.13$, "que lla teña eu" 4.8, "que $o$ agam" 8.8, 9.8, "que $o$ uiron e $o$ oýron" 1.17-18, tamén 2.16-17, "que $o$ ujron e oýron" 
3.15, 5.15-16, "que os tena" 8.10, 9.10, "que llo uirom e oýrom" 4.20, "que $l o$ uiron e oýron" 6.15-16, "estes IJ casares que me uós dades" 8.15, 9.15, "por esta erdade que les eu dou" 8.8-9, 9.8-9, "esta erdade que uos eu dou" 8.14, 9.14, "que uolla queira demandar" 15.6, "da herdade que uos nós demandauamos" 14.4-5, "que nunca uos seia demandada" 14.6, "que uos faça ende esta carta" 14.7, "como se uay aa Mámo[a]" 1.6 e "se algún ome da mj́a parte vos quiser demamdar este casar" 16.8-9. Tamén precede ó verbo cando se apoia nun cuantificador ou nun adverbio, como en "toda uola uendemos" 12.8, "todo esto les eu dou" 8.7-8, 9.7 e "outrosí me quito da demanda" 8.6-7, 9.6. Fóra destes casos a posición normal é a de enclítico ó verbo, como en "que díam ... IIJ moyos de cemteo ... et dárenlos estes IIJ moyos" 16.6,7-8, "nós ... anpar[ar]uos senpre a derecto" 11.7, "nós ... anpararuos senpre con ela" 6.7,8, 13.6,7, "dámosuola" 5.6, "nós senpre defendérmola" 1.10, "et quítoa et renúncoa a esse / ese moesteiro" 8.4-5, 9.4-5 e "damme eles a mjn IJ casares" 8.9, 9.9. Esta norma rómpese en "e $o$ uendemos a uós a monte e a fonte" 15.4 e en "Pedro Gunçáluez, notario, la iscriuío" 6.16, este último exemplo porque precede o suxeito e se equipara ós casos en que leva o relativo que, como en "Johán Eanes, que la iscriuío” 10.10, 11.11, 12.12-13 e 13.13.

7.3.1.1. Intercalación de palabras. Nas subordinadas, como o pronome se apoia no elemento que provoca a anteposición e non no verbo, é posible que se intercale algunha palabra entre o pronome e o verbo, como vemos en "estes IJ casares que me uós dades" 8.15-16, 9.15, "por esta erdade que les eu dou" 8.8-9, 9.8-9, "esta erdade que uos eu dou" 8.14, 9.14, "da herdade que uos nós demandauamos" 14.4-5 e "todo esto les eu dou" 8.7-8, 9.7, fronte a "se algún ome da mj́a parte vos quiser demamdar este casar" 16.8-9.

7.3.2. Uso da forma tónica con preposición. Unha particularidade importante nos pronomes na época medieval é o uso da forma tónica precedida da preposición $a$ en lugar da forma átona correspondente, especialmente en fórmulas paralelísticas, como en "fazemos carta de uençón ... a uós ... e ao conuento" 3.3-4,5, "fazemos carta de uençón ... a uós ... e a fillos de Johán Fernández" 5.2,4,5-6, "eu, P. E. de Lanpaça, con mía muler ... fazemos carta de uençón a uós ... e a el conuento" 4.2,3,4, parecido en 10.2, 11.2-3, 12.3, 13.2-3; "eu, María Pérez, con meu marido don Andreu, ffazemos carta de uençón a uós" 7.2-3, "ego, don Jullão, con mía muller María Páez, fazemos carta de uenciom a uós..." 10.1-2 e parecido en 11.1-3, "ffazemos carta de vençón a uós ... e alo conuento desse lugar de quanta herdade nós auemos" 6.2-4, "ffazemos carta de quitaçom a uós ..." 14.3, "todo esto vendemos a uós, abade" 1.7-8, "peite en couto á uoz del rrey L morauidís e a vós a herdade dublada” 15.6-7, etc. Hai un único caso en que aparece a forma átona acompañando á forma tónica con preposición, que é "por esta erdade que les eu dou, damme eles a min IJ casares" 8.8-9, 9.8-9. 
7.3.3. Uso do pronome suxeito. Nalgúns dos exemplos citados no parágrafo anterior podemos ver outra circunstancia que me interesa destacar, que é o uso relativamente frecuente do pronome suxeito. Isto prodúcese especialmente en contraposición con outros suxeitos ou con outros pronomes que non teñen función de suxeito. Vexamos máis casos: "que eu, Domjnga F., [et] eu, Mariña P., vendemos a uós, J. P., quanta herdade nós auemos en Lemeares ... e o uendemos a uós a monte e a fonte; et recibimos de uós en preco ... ssoldos, de quaes nós somos ben pagados" 15.1-3,4-5, "ego ... con mía muller ... ffazemos carta de uenciom a uós ... de quanta herdade nós auemos en Forcas ... et deste precio nós sumos ben pagados, et quanta herdade nós auemos en Secar de Boys" 12.1-2,3,4-5,6-7, "quanta herdade outra $e u$ aio en essa vila ... deste precio nós sumus ben pagados; e a tal preito que lla teña eu, Pedro Eanes, en meus días" 4.6,7-8; "eu, María Pérez, con meu marido don Andreu, ffazemos carta de uençón a uós ... de quanta herdade $e u$, M. P. aio ... Et eu, don Andreu, con mía muller ia dicta, damos a Monte de Rramo" 7.2-3,4,6, "que eu, dom Pedro Meéndez, ensembla cun mía muler dona Eluira R., damos e outorgamos ... o nosso cassar que nós auiamos ... se algún ome da mj́a parte vos quiser demamdar este casar, vós seerdes sempre anparados per mj́as bõas" 16.2-3,4,8-10, "se algún ome uener que esta carta queyra britar, nós ... anpararuos sempre con ela” 6.7-8. Máis exemplos pódense ver en 1.10-11, 2.2-4, 10.1-2,3-4,5-6, etc.

7.3.3.1. O uso da forma de suxeito non é, con todo, sistemática, e hai casos de alternancia no uso. Véxanse como mostra "como eu, Aras Pérez de Caldelas, dou ao moesteiro ... toda mía erdade que agu / ago en Senra, et quítoa et renúncoa ... e a demanda que fazía ... Outrosí me quito da demanda que fazía ... Todo esto les eu dou que o agam... et por esta erdade que les eu dou, damme eles a mjn IJ casares ... que os tena tanto en meus días ... Eu, Aras Pérez, deuo a amar e a defender a esse / ese moesteiro ... quanto eu poder ... Eu, A. P., deuo sempre a anparar a esse / ese moesteiro cun esta erdade que uos eu dou ... et vós a mjn outrosí cun estes IJ casares que me uós dades" 8.3,4,5,6-7,7-8,8-9,10,11-13,13-16, 9.3,4,5,6-7,7-8,89,10,11-12,13-16, "ego, Johán Pérez das Viñas, con mía muller María Rodrígez, ffazemos carta de uenciom a uós ... de quanta herdade nós auemos ... vnde sumos ben pagados. Et se algún ome uener que esta erdade queyra demandar, nós ... anpar[ar]uos senpre a derecto" 11.1-3,4,5-7, "eu, Teresa R., con meus fillos et con mías fillas, ffazemos carta de uençón a uós ... dứa uiña que auemos en S. et dun souto que auemos sobre Mouca ... et deste precio nós sumos ben pagados. Et se algún ome uener que esta herdade queyra demandar, nós ... anpararuos senpre con ela" 13.2-3,4-5,5-7, "eu, Pedro García, con mía muller Marina Pérez ... ffazemos carta de quitaçom a uós ... da herdade que uos nós demandauamos ... Et que nunca uos seia deman- 
dada, mandamos a P. G., notario, que uos faça ende esta carta" 14.1-2,3,45,6-7, "deste precio somos ben pagados et nós quitos daquela herdade ia dita" 5.6-7, etc. En moitos destes exemplos o pronome suxeito aparece porque está en aposición cun antropónimo, como é o caso tamén de "eu, Pedro Gunçáluez, que la iscriuj” 7.14-15, "eu, Pedro Guncáluez, notariu de Caldelas, que a fige" 8.22, 9.22, "eu, Pedro Guncáluez, notariu..." 15.13, 16.15-16.

7.4. Indefinidos. Nos indefinidos destaca a fórmula algún ome co valor de 'alguén', moi utilizada, pois está en 1.10, 2.7, 3.7, 4.10, 5.7, 6.7, 7.7-8, 10.6, 11.6, 12.9, 13.6, 14.7, 15.5-6, 16.8-9, e tamén a forma mijsmo 1.8.

7.5. Relativos. Entre os relativos debemos resalta-lo uso de vnde co valor de 'de que' en "por preçio nomẽado, XX ssoldos, vnde sumos ben pagados" 11.5-6 e o de quanto co valor de 'todo o que' en "eu, A. P., deuo a amar e a defender a esse / ese moesteiro dessusu ditu / dito quanto eu poder" 8.1113, 9.11-12.

7.6. O verbo.

7.6.1. Formas verbais. Entre as formas verbais podemos salientar britar 'romper, ir en contra' 1.10, 2.8, 3.8, 4.10, 5.8, 6.7, 8.13, 9.13, 10.6, conparey por 'comprei' 4.5, a variante diam 16.6, as formas arcaicas faça 14.7 e fao 7.15, a alternancia entre fez 1.17,18, 5.3 e fezo 14.17, as formas palatalizadas fige 8.22, 9.22, 15.14(2), 16.16,17 e pugi 8.23, 9.22, as variantes iscriuj 7.15, iscriuío $2.17,6.16,10.10,11.11,12.13,13.13$ e escriuir 14.16, así como oýrom 2.17 , 4.20, oýron 1.18, 3.15, 5.16, 6.16 e recibimos 15.4 , algunhas delas correspondentes ás formas que triunfaron en galego; tamén o valor típico medieval de iazer 'estar situado' en "dû́a leyra que iaz en Outer Rrauioso" 4.5. Outras formas verbais dignas de mención son "que fez pago dos dineros" en 1.17, co valor de 'pagou', e a alternancia entre ir e irse en "como se uay aa Mámo[a] ... et como vay alo porto” 1.6-7.

7.6.2. Uso do futuro de subxuntivo e outros tempos verbais. Nas condicionais é importante o uso do futuro de subxuntivo na prótase, seguido dunha subordinada relativa co verbo no presente de subxuntivo, e a apódose co verbo en infinitivo, ás veces co infinitivo conxugado, como en "se algún ome uener que esta carta queyra britar, nós senpre defendérmola per nós" 1.10-11, "se algún ome uener que esta carta queyra britar, nós ... anpararuos sempre con ela" 6.7-8, "se algún ome uener que esta erdade queyra demandar, nós ... anpararuos senpre a derecto" 11.6-7 e "se algún ome uener que esta erdade queyra demandar, nós ... anpararuos senpre con ela" 13.6-7. A fórmula pode tamén aparecer sen a oración de relativo, como en "se algún ome da mj́a parte vos quiser demamdar este casar, vós seerdes sempre anparados per mj́as bõas" 16.8-10. Outras veces a apódose leva o verbo en imperativo, como en "se algún ome uener ... que esta carta queyra britar, seia 
maldito" 2.7-9, "se algún ome uener ... que esta carta queyra britar, pecte..." 3.7-8, 4.10-11, igual en 5.7-8, 10.6, ou en "se algún ome uener que uola queyra demandar, pecte..." 7.7-8, 14.7-8, igual en 15.5-6 e parecido en 12.8-9. O futuro de subxuntivo aparece, por outra banda, nas construcións "Conoçuda cousa seia / sea a quantos esta carta uirem / virem / ujrem que..." 1.1-2, 2.1, 3.1-2, 4.1, 6.1, 7.1, 13.1, 14.1, "Conuçuda cousa sega a quantos esta carta virem que..." 15.1, 16.1-2 ou 8.2-3, 9.2-3 e en "quanto eu poder. Et quem este preito britar, peite..." 8.12-13, 9.12-13. O infinitivo conxugado pódese ver, ademais, en "et darmos deste nosu casar alo moestero una taega de pan" 2.6-7 e "que díam ... IIJ moyos de cemteo ... et dárenlos estes IIJ moyos delo Burgu atem a Ponte de Nauéoa" 16.6-8. En dous casos non hai diferencia de forma entre o infinitivo conxugado ou o non conxugado. Son "e a tal preito que lla teña eu, P. E., en meus días, e a mía morte ficar in paz alo moestero ia dito, et in meus días dar dela quarta de pan" 4.7-9.

7.6.3. Uso dos verbos aver e teer. En relación a estes dous verbos, debo indicar que os dous se usan co parecido valor de 'ter' que tiñan en latín. As formas do verbo ter que se documentan son tem 8.7, 9.7, tena 8.10, 9.10, teña 4.8, teñamos 2.4, teendo 8.17, 9.17, 15.9 e tenendo 1.12, 2.11, 3.11, 4.14, $5.11,6.11,7.11,13.9,14.11$. As formas de aver co valor de 'ter, posuír' son ago 9.4, agu 8.4, aio 4.6, 7.4, á 2.4, auemos 1.4, 2.3, 3.4, 5.3, 6.4, 10.4, 11.4, $12.5,7,13.4(2), 15.3$, auiamos 16.4 e agam 8.8, 9.8. O pequeno valor diferencial que presentan aver e ter co significado de 'ter' pode verse en "damos un casar de herdade que auemos en Castrelo alo moestero de M. de R., per tal preito que teñamos nós outro que á el moesteyro en essa vila” 2.2-4.

7.6.4. Uso dos verbos ser e estar. Canto ós verbos ser e estar, cómpre dicir que o segundo só aparece coa forma sta na frase "dû́a casa ... et sta sub signo de Santa Tegra" 5.4. O verbo ser ten varias funcións. Unha delas, moi frecuente, é a da formación da pasiva, como en "Conou da cousa seia" 1.12, 2.1, 3.1, 6.1, 7.1, 13.1, 14.1, "Conou da cousa sea" 4.1, "conuçuda cousa sega" 8.2, 9.2, 15.1, 16.1-2, "et que nunca uos seia demandada" 14.6 e "vós seerdes sempre anparados per mj́as bõas" 16.9-10. Outras veces o verbo vai seguido dun predicativo como en "seia maldito et scomongado" 2.8-9, "e a carta seia sempre firme" 3.8-9, "e a carta seia firme" 7.9, "deste precio somos ben pagados" 1.9, "desto somos ben pagados" 3.6, "deste precio somos ben pagados et nós quitos daquela herdade" 5.6-7, "deste precio nós sumus ben pagados" 4.7 e tamén 6.6, 10.5-6, 12.6-7, 13.5-6, "de quales nós sumos ben pagados" 7.5-6, "de quaes nós somos ben pagados" 15.5 e "por preçio nomẽado, XX ssoldos, vnde sumos ben pagados" 11.5-6. Noutras ocasións ten o valor normal de 'ser', como en "herdade ... que foy de nossu padre" 1.4, "eno casar que foy / foi de Pedro Carpenteiro" 8.5-6, 9.5-6, "Marina Pérez, filla que foy de Pedro Díaz" 14.2 e tamén en "fazemos carta de uençón 
dû́a herdade ... a uós, Eldora Pérez, muler que fui de Pedro Fernández" 5.2,4-5, na que se rompe o esquema, pois debería dicir fostes, e onde podemos interpretar como $1^{\text {a }}$ ou como $3^{\text {a }}$ persoa de singular. Como última posibilidade témo-lo valor de 'estar' na expresión "que presentes foron / forom / forun" 1.13-14, 2.12-13, 3.12, 4.15, 5.12, 6.12, 7.12, 8.18-19, 9.18-19, 10.7-8, 11.8, 12.10, 13.10, 14.12, 15.10-11, 16.12 e en "que presente fuj" 14.16.

7.7. Adverbios. Entre os adverbios son dignos de mención asusu 'arriba' e desusu / dessusu 'abaixo', que temos en "dela fonte de Leborín a asusu, assí como parte pela carreyra asusu" 11.4-5, "a esse moesteiro desusu dicto" 8.5, "a ese moesteiro desusu dito" 9.4-5, "a esse moesteiro dessusu ditu" 8.12 e tamén 9.12, "por este precio desusu dicto" 12.8. A forma demais 'ademais' aparece en "pecte a herdade en dublo et demais C morauidís" 7.8-9. O arcaico $u$ 'onde', aínda vivo na forma ulo? / ula?, aparece na frase "en Secar de Boys, $u$ dizem Rrogidoyro" 12.7-8 e o tamén arcaico ensembla 'conxuntamente' en "que eu ..., ensembla cun mía muler" 16.2-3. Ademais, tanto ten o valor de 'unicamente' en "que os tena tanto en meus días" 8.10, 9.10. Como adverbios pronominais aparecen as formas ende 'diso' e $y$ ( $h y, b i)$ 'nela', a primeira en "et que nunca uos seia demandada, mandamos a P. G., notario, que uos faça ende esta carta" 14.6-7 e a segunda en "et meu sinal $y$ faço" 7.15, "et meu sinno hi pugi" 8.22-23, 9.22, "et meu sinal by fezo" 14.16-17, "que esta carta fige e / et meu sinal hi fige" 15.14, 16.16-17.

7.8. Preposicións. A preposición $a$ xa vimos que se usa moito acompañando a unha forma tónica do pronome ( $\mathbb{7}$ 7.3.2), pero hai outros usos que debemos destacar, como o uso de dever $a+$ infinitivo en "eu, Aras Pérez, deuo $a$ amar e $a$ defender a ese / esse moesteiro dessusu ditu / dito quanto eu poder" 8.11-13, 9.11-12, "eu, Aras Pérez, deuo sempre $a$ anparar a esse / ese moesteiro cun esta erdade" 8.13-14, 9.13-14 ou a fórmula xa medieval "comuem a saber" 16.6. Típica medieval é a combinación coa preposición sobre en "dû́a herdade que auemos a sóbrela fonte" 5.2-3, "lugar nomẽado $a$ ssóbrelo Rrogidoyro" 14.5-6. Alterna con en en "de quanta herdade nós auemos en Forcas, alos Caruallos et in Cima de Uila" 12.4-5. Tamén é moi coñecida a expresión "des 'desde' ... $a$ ", que vemos en "dela fonte de Leborín $a$ asusu” 11.4. Ademais, a forma parte da locución conxuntiva a tal preito que, que alterna con per tal preito que, como vemos en "e a tal preito que lla teña eu" 4.7-8, "damos un casar ... per tal preito que teñamos nós outro" 2.2,3-4. A forma des tamén está en "todo esto les eu dou que o agam des aquí por sempre por erdade" 8.7-8, 9.7-8 e en "et dárenlos estes IIJ moyos delo Burgu atem a Ponte de Nauéoa" 16.7-8, frase na que, por outra banda, achamos a forma atem 'ata', pouco usada nos textos galegos. Outras formas dignas de destacar son sobre en "et dun souto que auemos sobre Mouca" 13.4-5; en, que aparece na expresión en meus días 'durante a miña vida', como se ve en 
"que lla teña eu, P. E., en meus días, e a mía morte ficar in paz alo moestero ia dito, et in meus dias dar dela quarta de pan" 4.8-9 e "que os tena tanto en meus dias ... que me uós dades en meus dias" 8.10,15-16, 9.10,15-16. Como particularidade témo-la falta da preposición en na expresión "da herdade que uos nós demandauamos lugar nomẽado a ssóbrelo Rrogidoyro" 14.4-6 e "quanta herdade nós auemos en Lemeares..., logar ditu Cima de Uila" 15.2-3. Finalmente debemos lembra-lo uso de per en "eu, Aras Pérez, deuo sempre a anparar a esse / ese moesteiro cun esta erdade que uos eu dou per min et per mías bõas" 8.13-15, 9.13-15, o uso da forma primitiva pera en "damos e outorgamos pera sempre ó m[o]steiro de M. de R. o nosso cassar" " 16.3-4 e o uso de por co valor de 'para' en "que o agam des aquí por sempre por erdade" $8.8,9.8$.

7.9. Conxuncións. Entre as conxuncións destaca o uso de que co valor de 'para que' en "et que nunca uos seia demandada, mandamos a P. G., notario, que uos faça ende esta carta" 14.6-7 e o da disxuntiva quer en "se algún ome uener, quer da nosa / nossa parte quer da alena / alẽa, que esta carta queyra britar" 2.7-8, 3.7-8.

7.10. Colocación das palabras. Cando o substantivo vai acompañado de dous determinantes é posible que un vaia anteposto e outro posposto, como en "fiquen aqueles casares anbos ia dictos" 2.5, "quanta herdade outra eu aio" 4.6, fronte a "en outro tal lugar" 4.11-12. Cando van xuntos outros e moitos, sempre aparece a mesma colocación: "et outro[s] mujtos que o uiron" 1.17, "et outros muytos que o uirom" 2.16, "et outros mujtos que o ujron" 3.14-15, "et outros mujtos que llo uirom" 4.20, "et outros mujtos que lo uiron" 6.15 .

7.11. Concordancia. Cando a data do documento remata en un é bastante frecuente que o substantivo seguinte concorde con ese último número en singular, como en "sub era de mil et CCC et un ano" 14.9, fronte a "sub era de mill et CC et nonaginta et VIJ anos" 6.9 ou "en era de mill et CC et nonaginta et VII anos" 13.14. Por outra banda, na concordancia do suxeito co verbo pode haber unha disociación singular - plural porque o suxeito eu vai seguido dunha coordenación introducida por con ou $e$ que contén unha referencia ás persoas actuantes. Ocorre isto en "eu, Pedro Pérez de Maçaneda, con mía muler dona Eluira, damos un casar" 2.2, "eu, Ffernán Fernández d'Aguijm, con meus fillos ... fazemos carta de uençón” 3.2,3-4, "eu, P. E. de Lanpaça, con mía muler E. V. et con meus fillos, fazemos carta de uençón" 4.2-3 e fórmulas semellantes en 5.1-2, 6.2-3, 7.2, 10.1-2, 11.1-2, 12.1-3, 13.2-3, 14.1-3. En lugar de nós ... vendemos, aparece como fórmula diverxente "que eu, Domjnga Fferrnández, [et] eu, Mariña Pérez, vendemos a uós...” 15.1-2. Noutro caso, aínda que o substantivo mosteiro está en singular, o verbo vai en plural porque inclúe a toda a comunidade, como vemos en "comuem a 
saber: ao mosteiro de M. de R., que diam cada ano a dom Pedro M. IIJ moyos de cemteo" 16.6-7. Máis cambio témolo noutro contexto, pois comeza "que eu, dom Pedro Meéndez, ensembla cun mía muler dona Eluira R., damos e outorgamos pera sempre ó m[o]steiro de M. de R. o nosso cassar que nós auiamos" e despois muda para "ao mosteiro de Monte de Ramo, que díam cada ano a dom Pedro Méndez III moyos de cemteo ... et dárenlos" 16.2-4, 6-8, de maneira que o que era suxeito se converte en obxecto indirecto. Con nomes xeográficos femininos o indefinido todo pode concordar ou non e nos nosos textos aparece coa forma masculina en "en todo Galiza" 4.14-15, 13.9-10, "en todo Galliza" 8.18, 9.18.

7.12. Léxico. Nos parágrafos anteriores xa citei numerosas palabras e a eles me remito, polo que neste apartado só quero facer unha referencia especial ós cultismos notario $2.17,6.16,10.11,11.12$, 12.13, 13.14, 14.7,15, notariu 8.22, 9.22, 15.13, 16.16, patrimonio 7.4, públicu 15.13, ppúblicu 16.16, ás formas juyo 4.12, juio 15.8 e conpla 'compra' 6.4-5, 10.4, á medida de capacidade taega 2.7 , ao arabismo alfayat 14.15 , ás moedas morauidís $2.9,3.8$, $4.11,5.9,7.9,8.13,9.13,10.7,12.10,15.7$, tamén de orixe árabe, e ssoldos 1.9, 3.6, 4.7.9, 5.6, 6.6, 7.5, 10.5, 11.5, 12.6, 13.5, 14.8, 15.5, 16.7, á fórmula carta de quitaom 14.3 e ó derivado do neutro plural Bona, adaptado como substantivo feminino co valor de 'bens', que vemos no singular bõa $1.11 \mathrm{e}$ no plural bõas" 6.8, 8.15, 9.15, 11.7, 13.7, 16.10 .

7.13. Antropónimos.

7.13.1. Nomes de persoa. Destaca o uso das formas Vaasco 3.12, 4.16, 5.14, 8.21, 9.21, 13.11, 14.13, 16.13 e Sanchio 16.13, xunto a Sancho 4.15,16, 5.15. Dentro das diversas posibilidades medievais para este nome atopámola forma Aras 8.3,11,13, 9.3,11,13 e outros nomes dignos de mención son Eldora 4.2, 5.4, Teresa 13.2 e Jullão 10.2.

7.13.1.1. Cando o nome vai seguido do apelido é normal que apareza cunha forma reducida, sempre que o permite o nome, e por iso temos casos coma "Martín + apelido" 1.14, 6.13, 10.8,10, 13.10,12-13, "Martj́n + apelido " 4.17, 11.8-9,10, 12.10,12, 15.12(2), "Pay + apelido" 2.14(2), 10.9, 11.9-10, 12.11, "Rruy + apelido" 4.19. O mesmo ocorre con "Meén Rodrígez" 5.15, fronte a "Meend'Eanes" 1.16, neste caso porque o apelido comeza por vogal. Por esta razón para o nome Fernando, cando vai seguido do apelido, adoptei a lectura Fernán, pois nos manuscritos está sempre abreviado ( $f$ ou $f f$ ), e así temos "Ffernán ou Fernán + apelido" en 3.2, 4.5,18, 6.14, 8.19,21-22, 9.19,21. Tamén lin así "Ffernán da Cela d'Allariz" 14.13.

7.13.1.2. Noutros casos aparece a forma plena, como en "Sueiro Méndez" 16.12 e "Gonçaluo López" 1.14-15, ou a abreviatura correspondente á forma plena e non á reducida, como en "Gona luo Migếez" 12.2 ou "García Moreira” 16.13. Tamén para Pedro, en lugar da forma Per, temos sempre a abre- 
viatura $P^{o}$, correspondente a "Pedro", seguida do apelido, en 1.12,18, $2.2,15,16,17, \quad 3.2,13(2), 15, \quad 4.2,8,20,21, \quad 5.5,12-13,13,14-15,16,6.12,13(2), 13-$ $14,16,7.13,14(3), 8.6,7,19,20,21,22$, 9.5-6,7,19,20,21,22, 10.8,9,11, 11.9(2),11, 12.11(2),13, 13.12(2),13-14, 15.11,12,13(2), 16.2,7,14,15-16. Por iso, cando só presenta a abreviatura $P$, tamén lin "Pedro + apelido" en 12.13 e 14.1-2,2,6$7,14,15$.

7.13.1.3. Caso importante é o de Rodrigo, que aparece nunha ocasión coma "Rruy Gunçáluez" 4.19, pero que nos outros casos está coa abreviatura $R^{o}$, correspondente a Rodrigo, e así lin "Rrodrigo García" en 1.13 e 7.12. Igual fixen cando só está escrito $R$ cun trazo que atravesa a consoante, como en "Rrodrigo García" 2.12, 3.12, 4,15, 5.12, 6.12, 8.18, 13.10 e "Rrodrigo Garchía” 9.18. Máis interesante é o caso de Rodrigo Afonso, pois o apelido comeza por vogal e, con todo, aparece a forma plena en "Rodrigu Afonso" 15.9-10 e a abreviatura $R^{\circ}$ ou $R$ cun trazo, interpretadas como "Rrodrigo Afonso" 1.13, "Rrodrigo Affonso" 7.11-12, 14.11, "Rrodrigo Afonso" 2.12, 3.11, 4.14, 5.11, 6.11, 8.17-18, 13.9 ou "Rrodrigo Alfonsu" 9.17-18.

7.13.2. Uso de antropónimos como nomes ou apelidos. O nome Afonso aparece aplicado ó rei Afonso X coa alternancia das formas galega e castelá, como vemos en "don Afonso" 1.11, 2.10, 3.10, 4.13, 5.10, 6.10, "don Affonso" 14.10, 16.10 e "don Alfonso" 7.10, 13.8, 15.8, "don Alfonsu" 8.16, 9.16. Por outra banda, aparece como apelido no citado "don Rrodrigo Afonso" 1.13, 2.12, 3.11, 4.14, 5.11, 6.11, 8.17-18, 13.9, "don Rrodrigo Affonso" 7.11-12, 14.11, "do[n] Rodrigu Afonso" 15.9-10 e "don Rrodrigo Alfonsu" 9.17-18, personaxe que ten ó seu mando Caldelas. Outro antropónimo que aparece como nome e apelido é Andreu, pois, por un lado, temos ó Adiantado do rei en Galicia "don Andreu", 14.12, 15.10, 16.12, así como "don Andreu" 4.18, 7.26, "don Andreu d'Agijn” 5.14 e "Andreu Eanes” 3.14, ou "Andreu Eanes d'Agij́n / d'Agij́n" 8.21, 9.21, 14.14, 16.15, e, por outro, "Johán Andreu" 5.1-2.

7.13.3. Personaxes co tratamento de don. Alén do rei e dos citados don Rodrigo Afonso e don Andreu, que é Adiantado do rei en Galicia e presenta alternancia, hai outros personaxes que levan o tratamento de don, como o Meiriño Maior "don Rrodrigo García” 1.13, 2.12, 3.12, 4.15, 5.12, 6.11-12, 7.12, 8.18, 13.10, "don Rrodrigo Garchía" 9.18; o bispo de Ourense "don Johán" 1.12, 2.11 ou "don Johán Díaz" 3.10-11, 4.13-14, 5.11, 6.10-11, 7.11, 8.17, 9.17, 13.9, 15.9, 16.11; o abade de Montederramo "don Johán" 1.8, 14.4 ou "don Johane" 3.5 ou "don ffrey Iohane" 4.3, 13.3 ou "don ffrey Johane" 6.3, 7.3 ou "don ffrey Johán" 10.3, 11.3, 12.3. O comendador de San Lourenzo aparece como "don Martín Fernández" 10.8, 13.10 e "Martj́n Fernández" 11.8-9, 12.10. Sen este tratamento están o xuíz de Caldelas "Pedro Pérez" 5.12-13, 6.12, 8.20, 9.20 e os cabaleiros "Gonçaluo López" 1.14-15, "Rruy Gonçáluez" 4.19 e "Meén Rodrígez" 5.15. Fronte ó prior "don Sancho" 4.15, 
non leva o tratamento o subprior "Vaasco Pérez" 4.16 e entre os monxes aparecen "don Pedro" e "don Martino" 2.13, pero "Sancho Eanes" 5.15. Tampouco o levan o arcediago "Pedro Eanes" 1.12 e os cregos, prelados ou capeláns que figuran coma testemuñas, como en 1.14,15,16, 2.15, 6.14,15, 10.9(2), 11.9,10(2), 12.11(2), 15.12, 16.13,14.

7.13.3.1. Entre os personaxes importantes, cando actúan o home e maila muller, hai varias posibilidades, pois poden aparece-los dous co tratamento, como "dom Pedro Méendez" 16.2,7 e a súa muller "dona Eluira Rodrígiz" 16.3; pode aparece-lo home e non a muller, como en "ego, don Jullão, con mía muller María Páez" 10.1-2 ou "eu, María Pérez, con meu marido don Andreu ... eu, María Pérez ... eu, don Andreu" 7.2,4,6, e pode aparece-la muller e non o marido, como en "eu, Pedro Pérez de Maçaneda, con mía muler dona Eluira" 2.2.

7.13.4. Apelidos. Entre eles resaltarei o uso das formas Uaásquez 1.3,5, 5.13 e Vaásquez 4.2, 8.20-21, 9.20, fronte a Páez 4.5, 6.13, a forma impropia Múogu 4.16-17 e a forma Michel $(m \overline{i c h l})$ 16.14, que podería ser unha grafía desaxustada por Migéez.

7.13.4.1. Normalmente as testemuñas levan o apelido e, de todos eles, cómpre destacar "Pedro Abbellom" 6.13, "Fernán Canbade" 8.19, 9.19, "Johán Canpelo" 1.16, "Domingo Cañoto" 13.12, "Pedro Carpenteiro" 8.6, 9.5-6, "Pedro Carreyra" 3.13, "Pedro Cide" 8.19, 9.19, "Fernán Correicas" 8.21-22, 9.21, "García Moreira” 16.13, "Johán Mouro" 2.15, "Pedro Mouro" 15.12, o citado "Johán Múogu" 4.16-17, "Pedro Muozino" 10.8, 11.9, 12.11, "Pedro Pixota" 5.14-15, "Domingo Roça" 2.14-15, "Pedro Santiago" 7.14 e tamén "Johán Eanes Correa" 8.19-20, 9.19-20, que alterna con "Johán Correa" 5.13, 14.13.

7.13.4.2. Estes apelidos, ás veces, van acompañados da indicación do lugar, como en "Lope Uaásquez de Santisso" 1.5, "Pedro Pérez de Maçaneda" 2.2, "Pedro Uiuez du Burgo" 2.16, "Johán Pérez da Rrasa" 3.14, "Pedro Eanes de Lanpaça" 4.2, "Ffernán Eanes de Canba" 4.18-19, "Pedro García de Ueyga" 4.20, "Johán Andreu do Souto" 5.1-2, "Pedro Fernández de Moaas" 5.5, "Vaasco Pérez de Ualderriquia" 5.14, "Martín Páez du Burgo" 6.13, "Pedro Eanes de Candaendo" 6.13-14, "Domingo Pérez de San Fijz" 6.14-15, "Domingo Gunçáluez da Coua" 7.13, "Pedro Fernández de Pedrouços" 7.14, "Andreu Eanes d'Agiín / d'Agij́n" 8.21, 9.21, 14.14, 16.15, "Johán Pérez das Viñas" 11.2, "Vaasco Rodrígez do Burgo" 13.11-12, "Pedro Eanes d'Aguij́n” 13.12, "Martín Domj́ngez de Canba" 13.12-13, "Pedro Díaz de Secar de Bois" 14.2-3, "Fernán da Cela d'Allariz" 14.13, "Pedro Uaásquez da Rrúa Noua" 14.14, "Pedro Domj́ngez das Uinas" 15.11-12, "Sueiro Méndez de Ual do Nero” 16.12 e "Johán Fferrnández de Mones" 16.14. Hai alternancia entre "Aras Pérez de Caldelas" 8.3, 9.3 e "Aras Pérez" 8.11-12,13-14, 9.11,13 e nalgúns casos o apelido só indica o lugar de procedencia, como "Johán de Samartino" 1.15, 
8.19, 9.19, "Johán de Samartjno" 4.17, "Saluador de Queyroga" 4.19, "Johanino de Lemeares" 15.11 ou "García de Roínda" 16.13-14. Aparece sen o apelido "Johán, clérigo de Quoto" 1.16, pois non parece probable que clérigo sexa neste caso apelido.

7.13.4.3. Como nos documentos temos moitas veces a presenza do pai e mais dos fillos, podemos ver como, en xeral, os fillos levan como apelido a forma correspondente ó nome do pai, como en "eu, Ffernán Fernández d'Aguijm, con meus fillos Pedro Fernández et Marina Fernández et María Fernández et Domjnga Fernández" 3.2-3, "Johán Fernández, fillo de Ffernán Eanes" 4.18, "Pedro Pérez, iuíz de Caldelas; sou padre Pedro Uiuéyz" 6.12-13 ou "Marina Pérez, filla que foy de Pedro Díaz" 14.2. Pero tamén pode ocorrer que o fillo leve o mesmo apelido có pai, como en "eu, Pedro García, con mía muller Marina Pérez ... et con nossu fillo Johán García” 14.1-3, ou que varios fillos leven o apelido correspondente ó nome do pai e que un deles tome o mesmo apelido que ten o pai, como en "eu, Sancha López, con mías irmanas Marina López et Sancha (sic) López et María Uaásquez, todas irmanas" 1.2-3, que son fillas de "Lope Uaásquez de Santisso" 1.5. Nuns cantos casos só aparece o nome do fillo ou da filla sen apelido: "Marina" 5.2,4, "Gonçaluo Migếez, con mía muller Eluira Sánchez et con meus fillos Johane et Pedro et Martiño" 12.2-3.

7.14. Topónimos. Entre os topónimos debemos lembra-las formas Aguijm 3.2,4, Aguijn 7.5,13, 13.12, 14.14, Agij́n 5.14, 9.21, 16.15 ou Agiín 8.21 'Aguil', Candaendo 6.14 (2) 'Candedo', Lanpaça 4.2,6 'Lampaza', Lemeares 1.14, 15.3,11,12 'Lumeares', Maçaneda 2.2 'Manzaneda', Moaas 5.5 'Moás'; Nauéoa 16.8,14 'Navea', Outer Rrauioso 4.5 por 'Outeiro', Queyroga 4.19 'Quiroga', Quoto 1.5,16 'Coto', Rjuu de Cabras 1.7 (hoxe será 'Río de Cabras'), Rrogidoyro 12.8, 14.5 (hoxe será 'Ruxidoiro'), Saas do Monte 16.5 'Sas do Monte', San Fijz 6.15 'San Fiz', San Gurgu 16.15 'San Xurxo ou Santiurxo?', Santisso 1.5 'Santiso', Secar de Boys 12.7, 14.6 e Secar de Bois 14.2-3 'Sacardebois', Ualderriquia 5.14 'Valderrique' e Ual do Nero 16.12 '¿Valdonedo?', así como Pena Petada de Triues 8.9, 9.9 e Santa Tegra 5.4 'Santa Tegra de Abeleda'.

7.15. Fórmulas latinas. En textos tan antigos é moi corrente a aparición de fórmulas latinas ou de carácter latinizante, ás veces, falsamente latinizantes. Estas fórmulas poden atoparse en calquera posición dentro do texto. Así, hai moitos documentos que comezan cunha frase en latín e despois continúan en romance, como "In Dei nomine amen" 2.1, 3.1, 4.1, 6.1, 7.1, 13.1, "In Dei nomine amen. Notum sit presentibus et futuris quod ego, Johán Andreu..." 5.1-2, "In Dei nomine amen. Notum sit tam / tan presentibus quam futuris quod ego... 10.1, 11.1, 12.1, "Jn Dej nomine amen. Sub era $\mathrm{M}^{\mathrm{a}} \mathrm{C}^{\mathrm{a}} \mathrm{C}^{\mathrm{a}} \ldots$.." 8.1, 9.1, "Sub era $M^{\mathrm{a}} \mathrm{CC}^{\mathrm{a}} \operatorname{LXXXX}^{\mathrm{a}} \mathrm{V}^{\mathrm{a}}$, jn mense september" 1.1 e "Era $\mathrm{M}^{\mathrm{a}}$ $\mathrm{C}^{\mathrm{a}} \mathrm{C}^{\mathrm{a}} \mathrm{C}^{\mathrm{a}} \mathrm{IJ}$ anos" 16.1 . 
7.15.1. En posición interna podemos citar adaptacións ou fórmulas que mesturan romance e latín como "Rregnando rrey / rey don A." 1.11, 3.10, 4.13, 6.10, 7.10, 13.8, 14.10; "rreynando rey don A." 2.10, "rrenando rrey don A." 5.10, ou noutros co cambio para a forma "rreinaua / rreynaua rey don / dom A." 8.16, 9.16, 15.8, 16.10; "tenendo Caldelas don..." 1.12-13, 2.11, 3.11, $4.14,5.11,6.11,7.11,13.9,14.11$, "teendo Triues et Caldelas don..." 8.17, 9.17, "teendo Calldelas do[n]..." 15.9; "que presentes foron" 1.13-14, 2.12-13, 3.12 , 4.15, 5.12, 6.12, 7.12, 10.7-8, 11.8, 12.10, 13.10, 14.12; "qui foron presentes" 8.18-19, 9.18-19, "qui presentes forun" 15.10-11 e "qui presentes foron" 16.12; "Johán de Samartjno, presbiter, testis" 4.17; "sub signo de..." 5.4, 6.5, "sub sino / sinno de..." 15.3, 16.5; "ffecta a carta jno mes de setembro, en era $M^{a} C^{a} C^{a} X X X X^{a} V^{a}$ " 2.9-10, "fecta a carta en era $M^{a} C C^{a} \operatorname{LXXXX}^{a} V^{a}$, jn mense outuber" 3.9, "ffecta a carta inno mes de juyo, en era $M^{a} C^{a} L^{2} L^{a}$ VJ" 4.12, "anpararuos ... a derecto. Ffecta a carta VIJ días ante kalendas marcias, sub era de mill et CC et nonaginta et VIJ anos" 6.8-9, "ffecta a carta VJ días de nouembrio, sub era $\mathrm{M}^{\mathrm{a}} \mathrm{CC}^{\mathrm{a}} \mathrm{XC}^{\mathrm{a}} \mathrm{VIJ}^{\mathrm{a}}$ " 7.9-10, "ffecta a carta ... en era $M^{a} C^{a} C^{2} X_{X X X}^{a} V J^{a}$ " 5.9-10; "ffecta a carta ... en era $M^{a} C^{a} X^{a}{ }^{a} V I J " 10.7$, "a derecto. Ffecta a carta no mes de marcio" 11.7-8, "ffecta a carta no mes de marcio" 13.7-8, "ffecta a carta X días andados d'abrjl, sub era de mil..." 14.9, xunto a "feyta a carta XV días de juio, era $\mathrm{M}^{\mathrm{a}} \mathrm{C}^{\mathrm{a}} \mathrm{C}^{\mathrm{a}} \mathrm{C}^{\mathrm{a}} \mathrm{IJ}$ " 15.7-8.

7.15.2. En posición final podemos citar "en era de mill et CC et nonaginta et VII anos" 13.14; "Pedro Gunçáluez qui notuit" 3.15, 4.21, 5.16. Noutros adáptase esta fórmula ó galego: "Pedro Gunçáluez, que a fez" 1.18 ou "Pedro Gunçáluez, notario, que a iscriuío" 2.17, etc.

7.15.3. Tamén é unha adaptación do latín a coñecida fórmula "conoçuda cousa seia / sea a quantos..." 1.1-2, 2.1, 3.1, 4.1, 6.1, 7.1, 13.1, 14.1, "conuçuda cousa sega a..." 8.2, 9.2, 15.1, 16.1-2, así como "quanta herdade nós auemos en Lemeares..., logar ditu Cima de Uila" 15.2-4, "da herdade que uos nós demandauamos lugar nomẽado a ssóbrelo Rrogidoyro" 14.4-5. Véxanse ademais palabras ou fórmulas estrañas ao galego como "testis" $3.12,13(3), 14(3), 4.15,16(2), 17(2), 18(2), 19(2), 20(2)$; "pecte" 2.9, "pecte en copto" 3.8, 4.11, 10.6, 12.9, 14.8, "peyte en capto" 5.8, "octaua" 4.4, "conparey" 4.5, "sumus" 4.7, "in paz" 4.8, "in meus días" 4.9, "derecto" 4.10, "subprior" 4.16, "episcopo" 8.17, 9.16, o apelido "Pedro Sancij, Diagu Sancij" 15.13 , etc. 

EDICIÓN 



\section{7, Seteabro.}

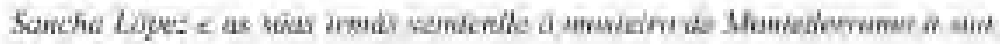
Aerabuic do $\operatorname{Col} \omega_{\text {. }}$

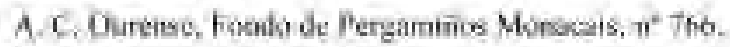

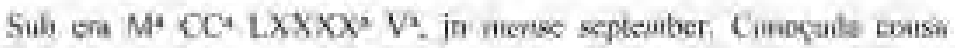

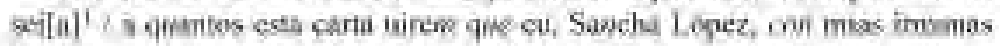

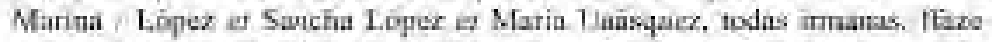

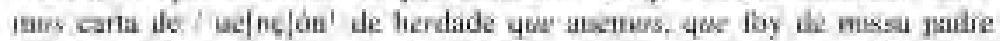

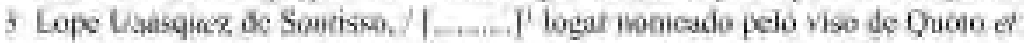

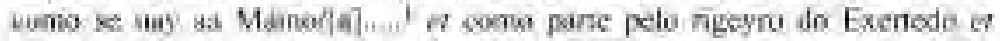

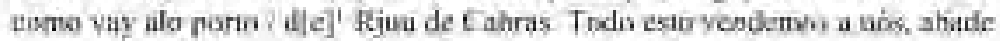

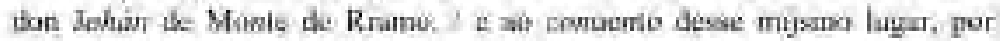

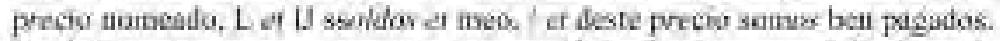

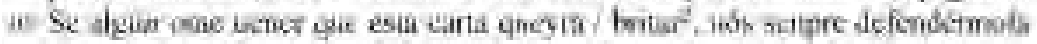

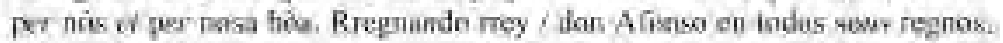
by

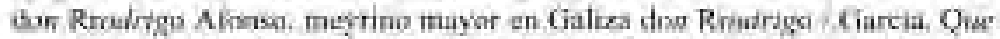

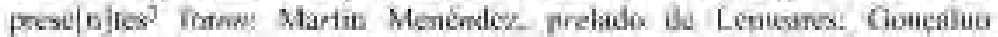

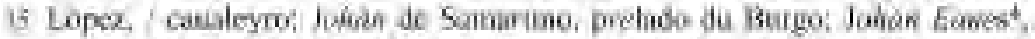

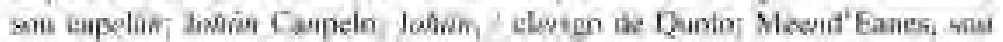

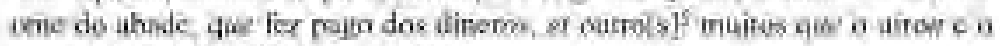
vy̆un. Pes/ro Guradace, que a fez

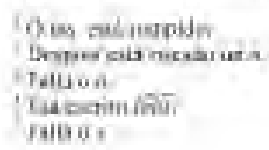

\section{5\%, Secombro.}

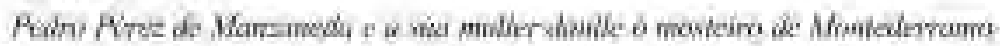

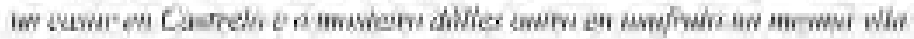
A. H.N. Clero. Lapea last doc. " h. 
In Dei nowine anew, Conocuda cousa keik a quinos este carta wirem que

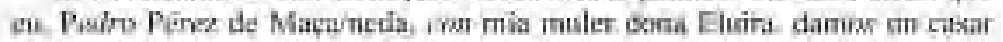

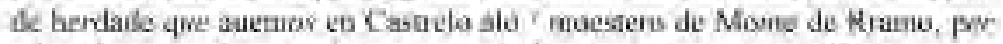

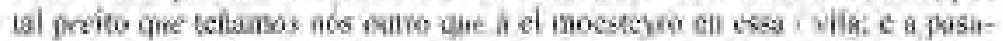

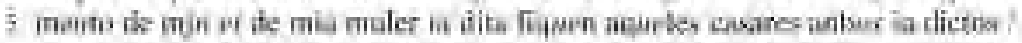
alo misestera de Mowe de ferame un paz: ef dirmos beste axsu casat alo

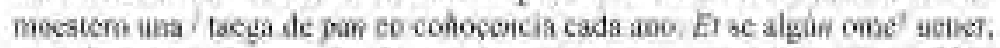

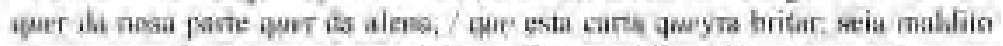

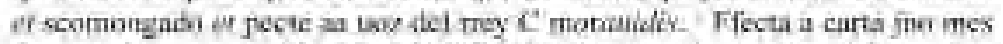

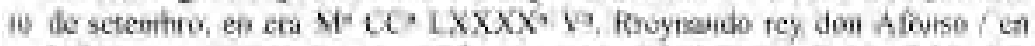

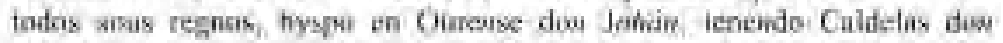

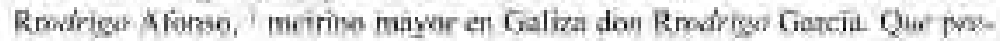

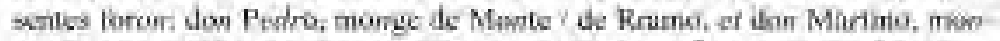

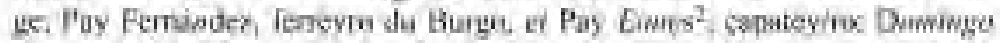

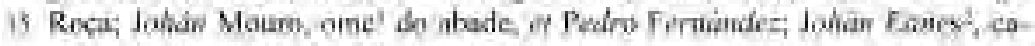

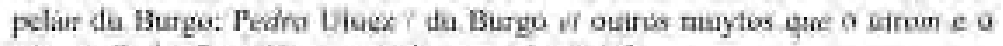

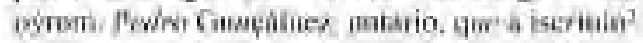

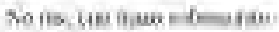

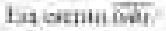

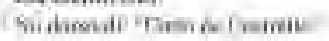

\section{7, Outahris.}

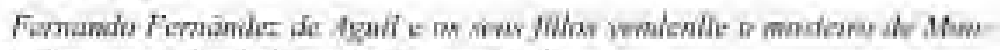

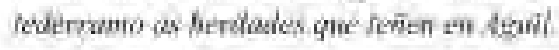

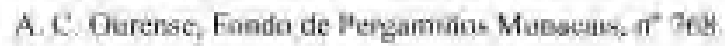

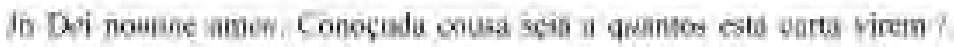

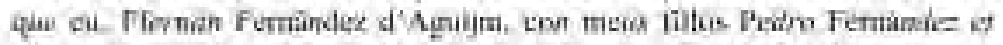

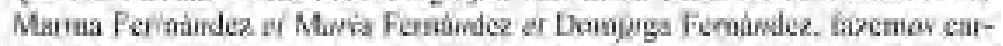

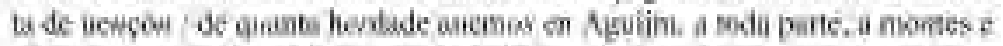

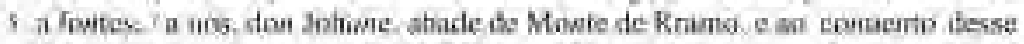

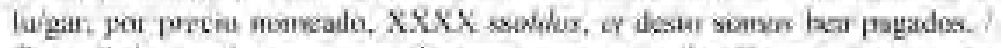

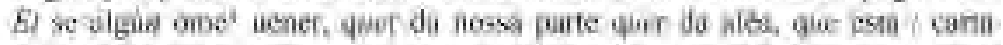

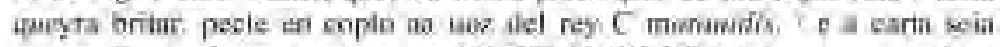

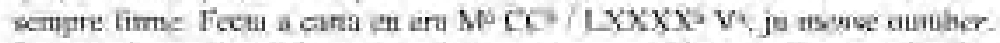

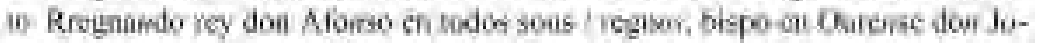

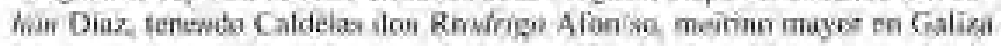

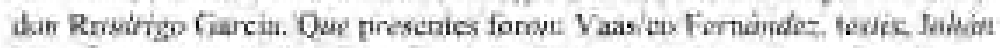

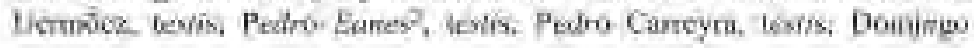




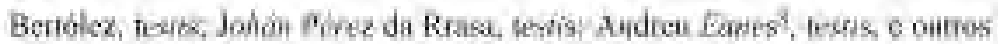

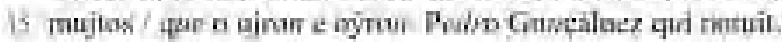

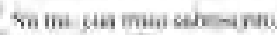

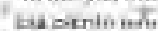

fe peate 6 Wh,
}

\section{4}

1258, Xuîte,

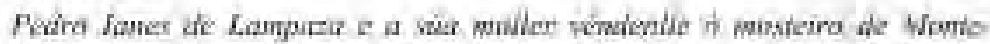

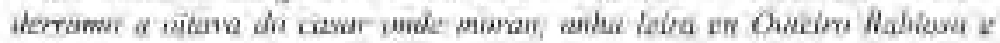

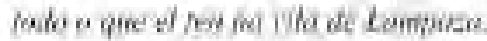

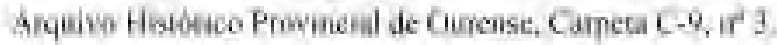

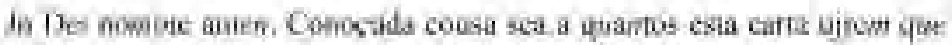

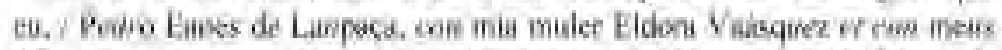

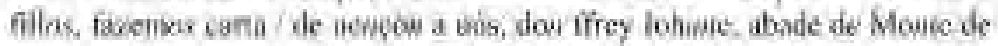

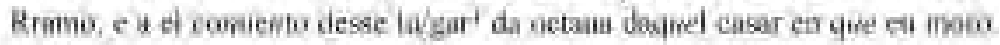

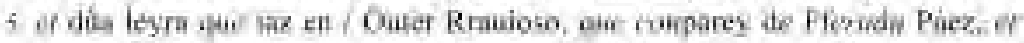

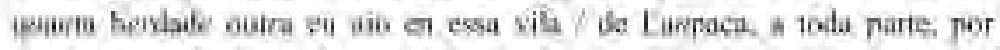
precid nomendo, L sondor, of deste precio vös sumus / ben mandes: $\mathrm{c}$ a tal

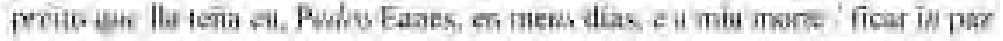

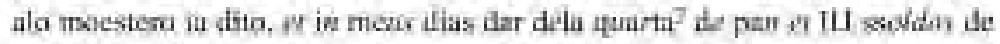

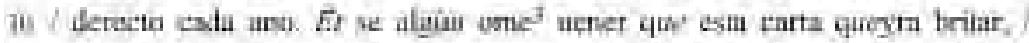

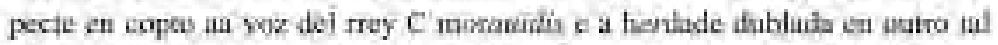

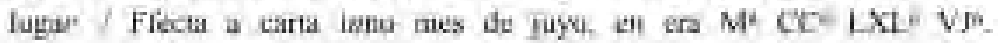
Rregnardo rey / don Alimso ent todas sons regnos, tnspor ell Quranse dan

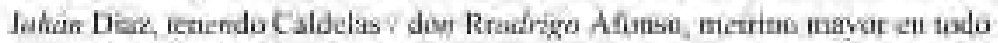

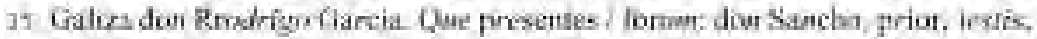

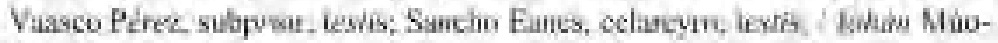

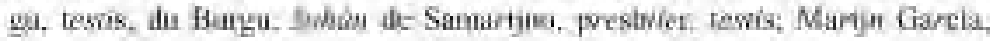

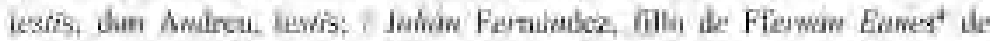

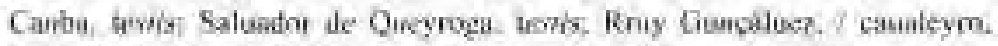

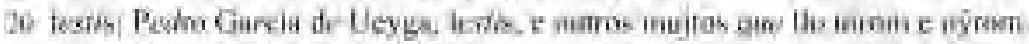

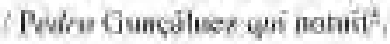

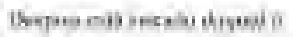

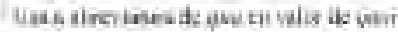

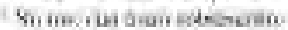

this wantious:

'Nillimeili. Creacelaras'
} 


\section{5}

\section{Fehreiro.}

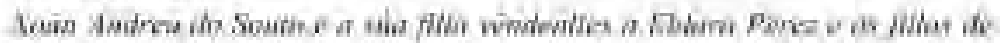

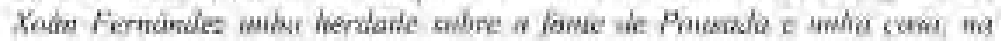

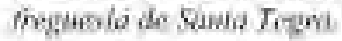

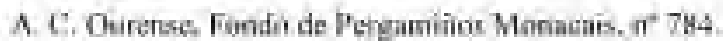

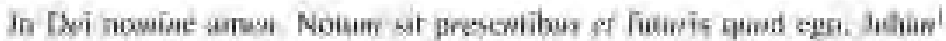

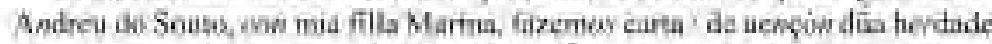

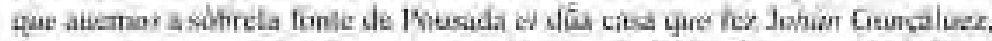

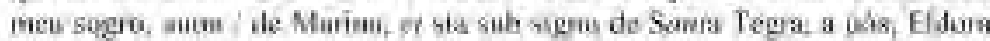

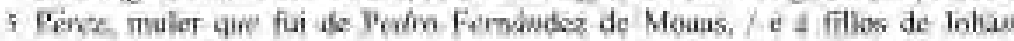

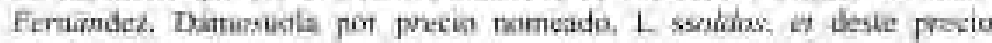

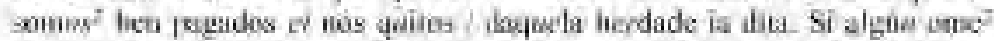

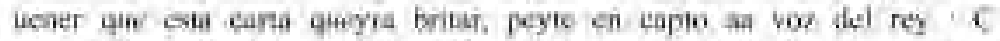

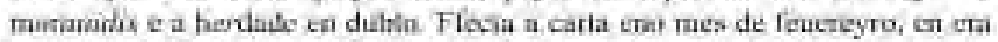

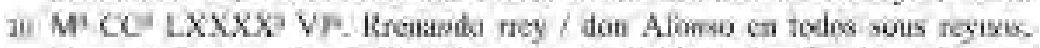

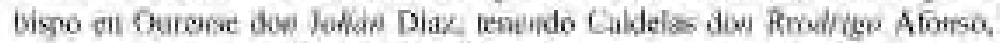

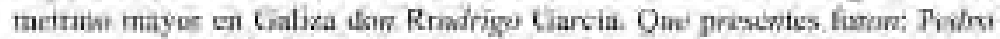
Pérez, fulz de Caldelas. Psobra Uiuey2, Deiningo Ladsquez, Jahán Cimea ?

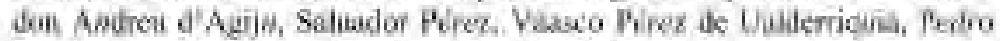

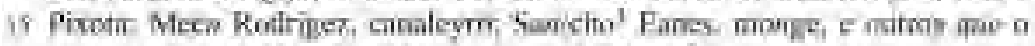

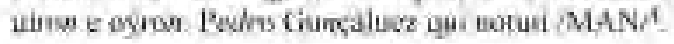

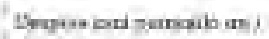

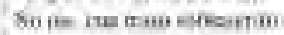

oreasesenty

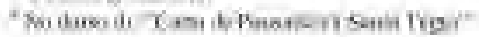

\section{6}

1250. Feinciro, 23.

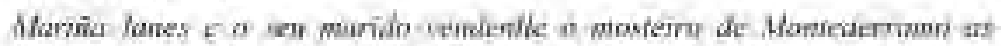

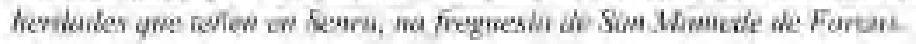

A C. Durense; Fondo de Pergamiòos Moracais. $\pi 20$

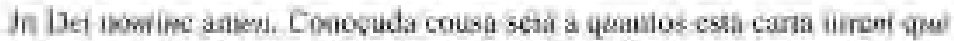

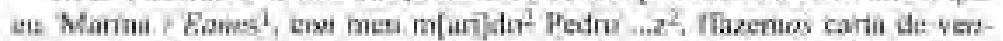

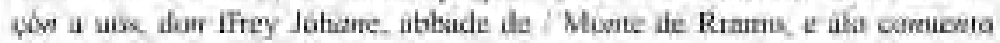

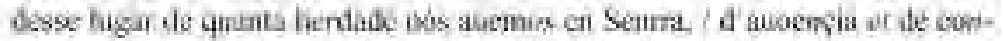

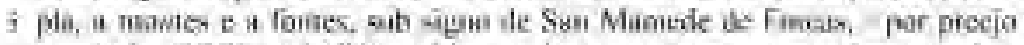

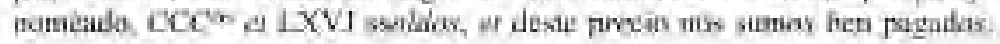




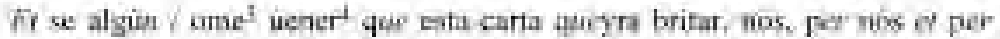

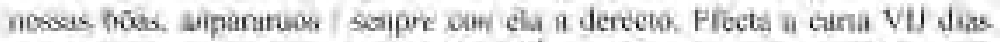

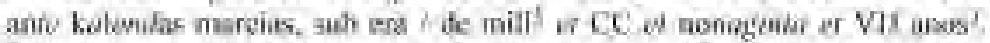

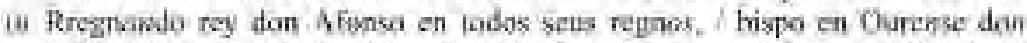

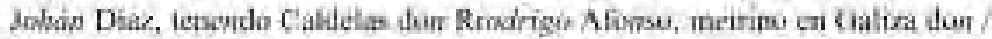

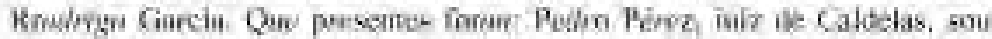

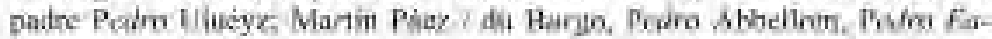

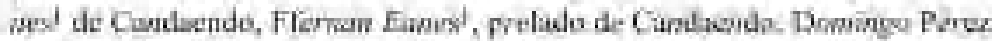

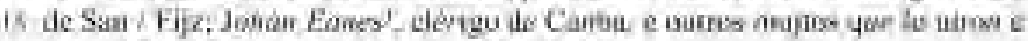

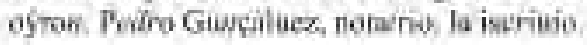

fosmanti

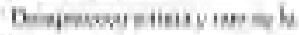

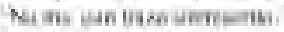

"Anins esolposedioni

1259. Novemliru, i.

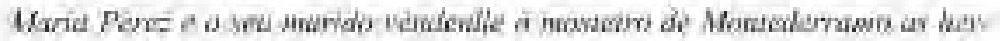

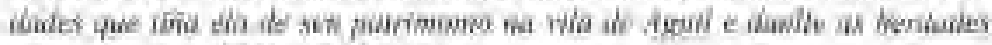

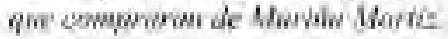

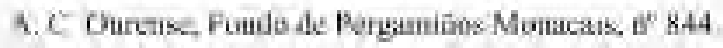

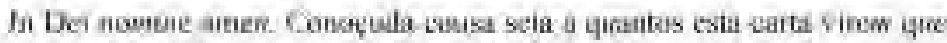

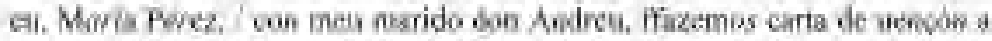

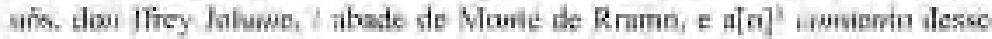

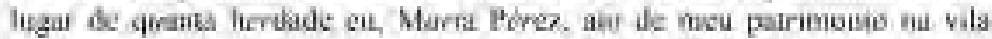

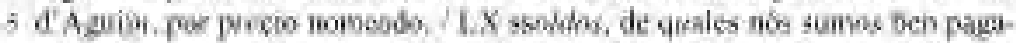

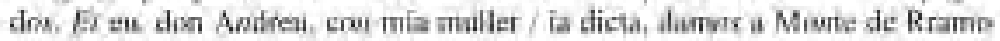

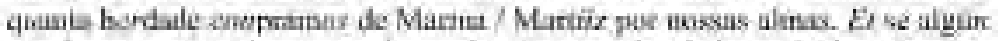
oiné veser ove wola girezra demandac / pecte a hendade co dablo er demais.

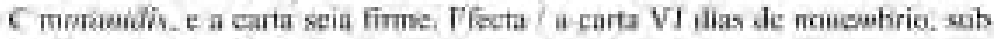

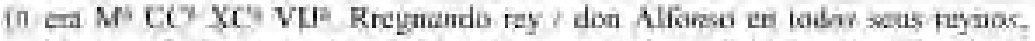

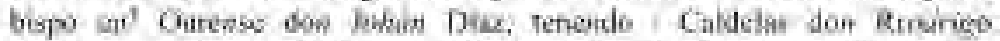

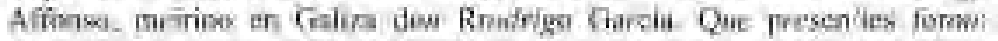

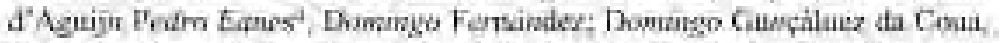

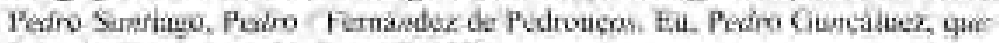

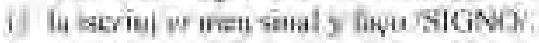

\footnotetext{
Eas serar d crawam

Ne ais cas irom serrsensi.

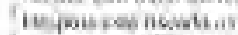

Hass exranide
} 
1260., Febreiru, 24

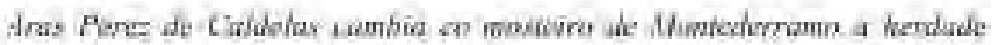

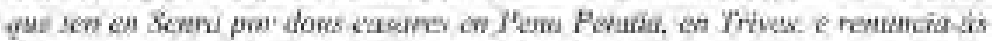

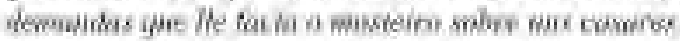

A. S. Ourense, Fundo de Pergumtinsis Munscaix, nt X52, Esie documeahe fai certa parioda co secterinte.

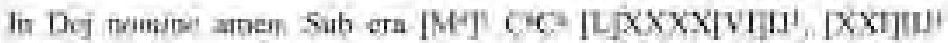

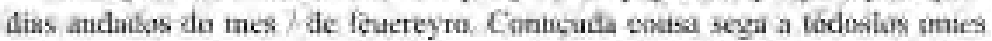

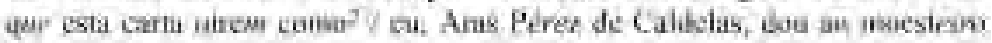

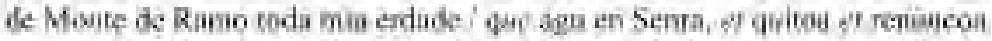

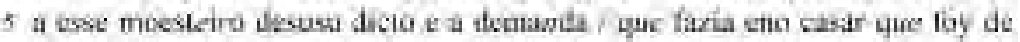

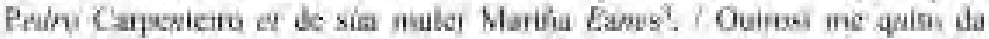

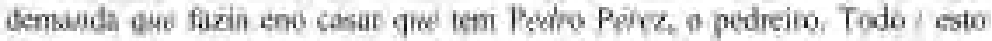
les cu daur que o agam des aqui por sempre por cribade, of par ente ardade

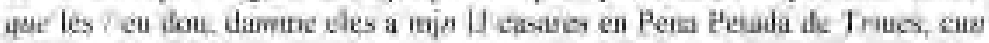

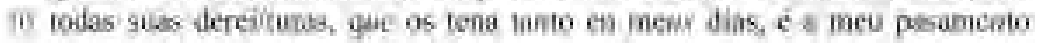

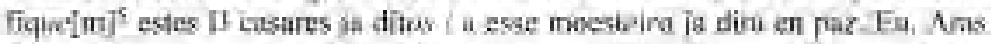

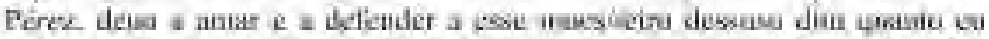

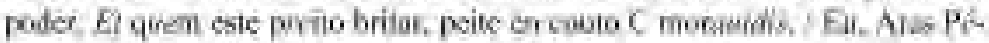

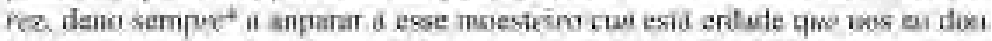

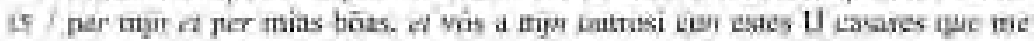

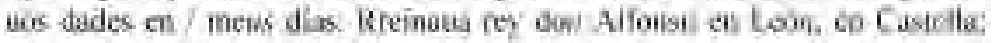

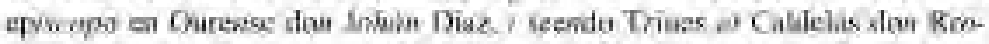

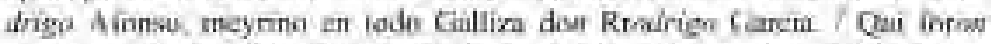

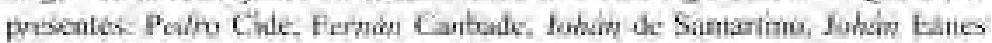

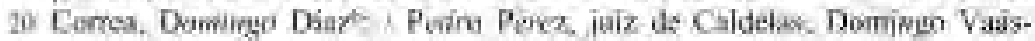

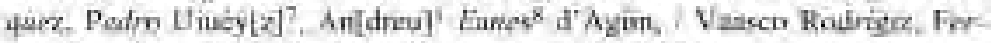

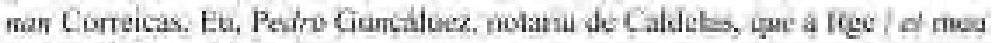

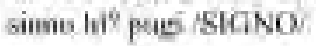

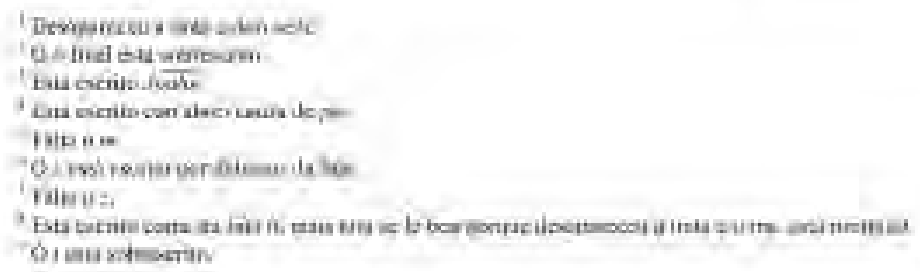




\section{Gi, Feturvire, 24.}

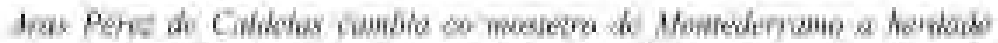

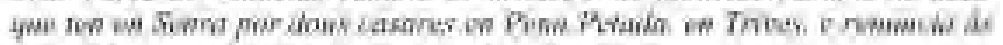

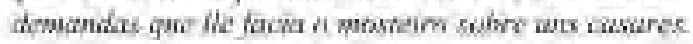

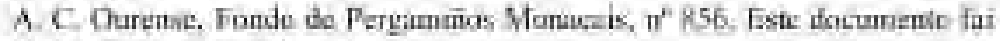
carts partidu so antotiot.

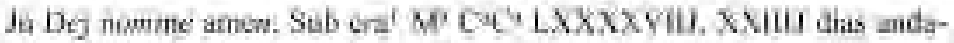

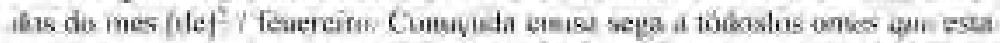

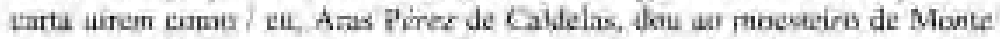

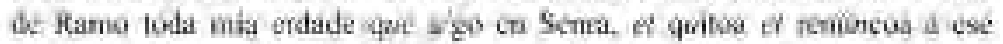

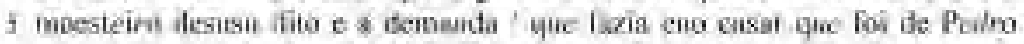

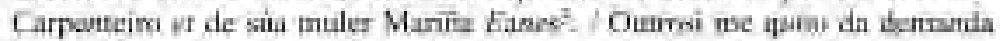

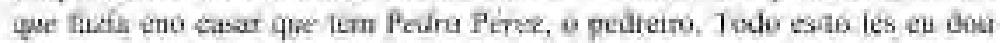

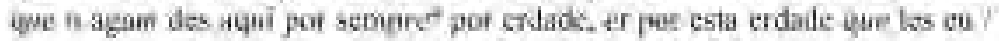

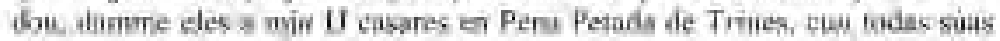

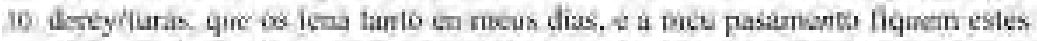

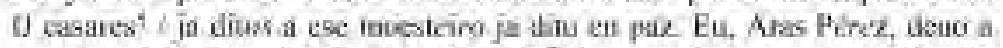

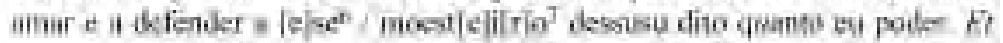

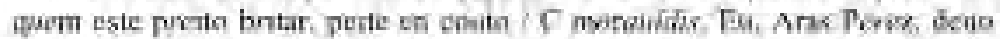

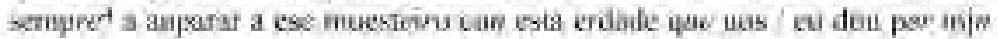

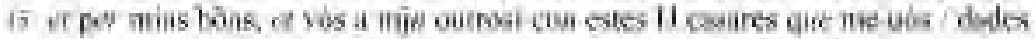

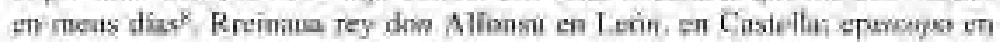

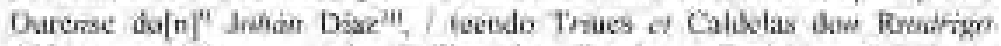

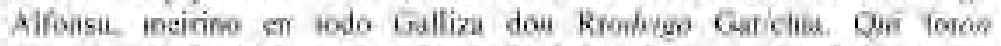

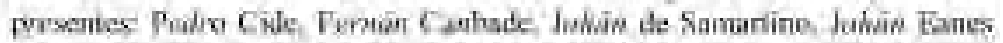

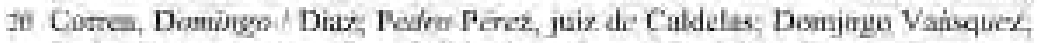

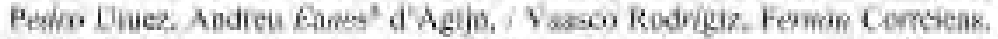

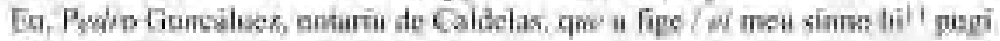
SIGINO.,

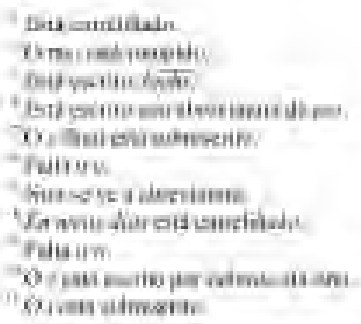




\section{0}

\section{Marze.}

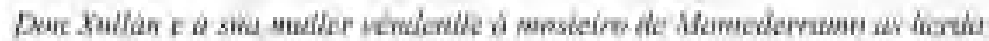
Wos que fedew en Sema.

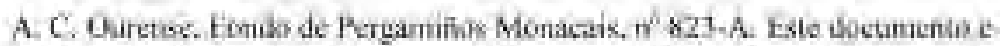

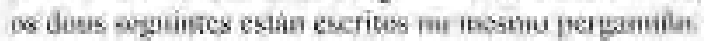

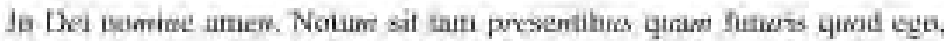

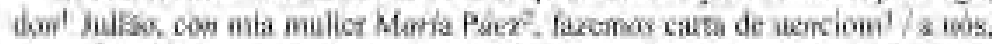

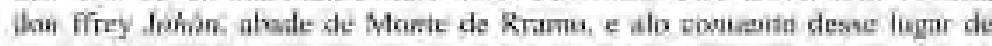

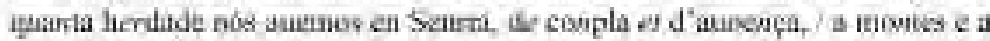

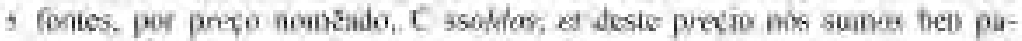
pados, Ef se aligue unet venes qur esta carta queyra / hrìian pecie en copvo $\mathrm{C}$

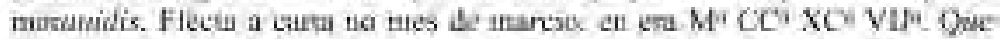

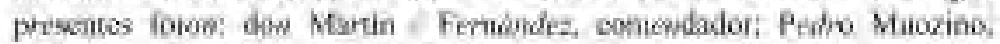

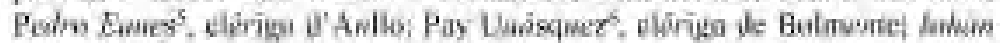

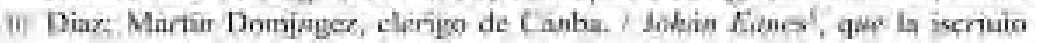
per mandedo de Pedro Coimsaluey, notario.

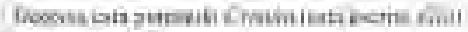

I Eusonatope

1 Losomil

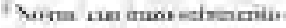

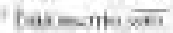

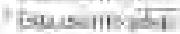

\section{1}

\section{[1259), Marai.}

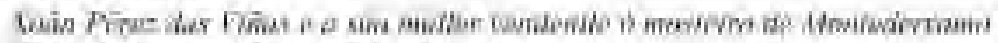

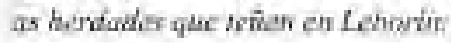

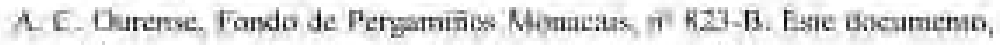

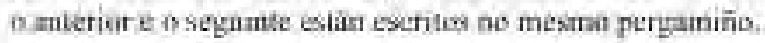

In Dei aboune amwer. Notum sit tan prosentibas quam futaris quod ego,

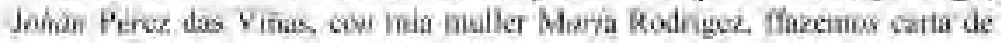

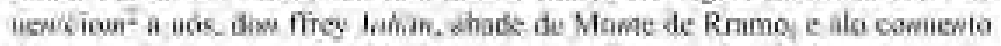

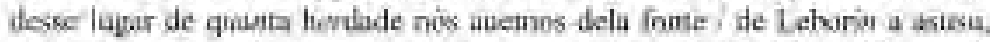

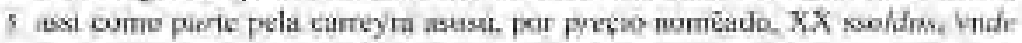




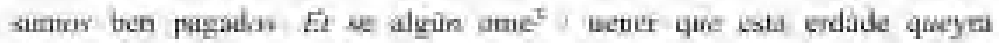

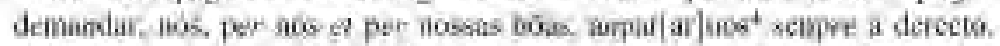

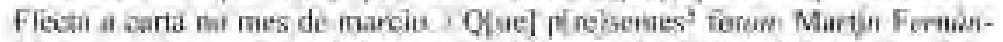

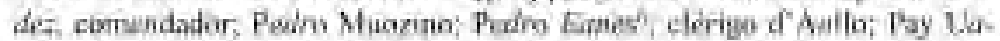

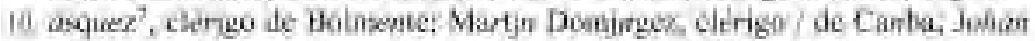

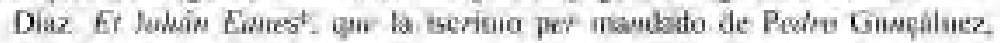
nuentio

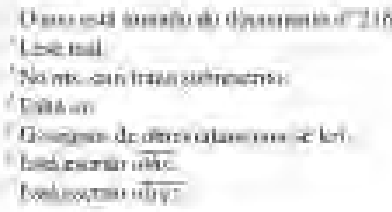

\section{(1259. Marros)'.}

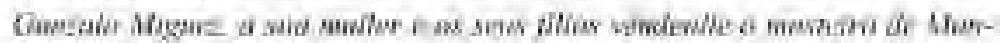

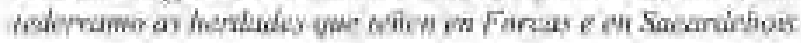

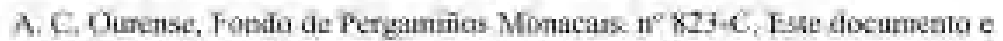
ns dous anterions estin escritos no mesmod pergamine.

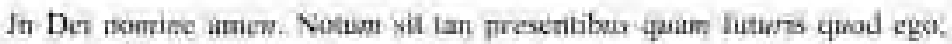

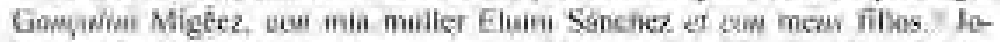

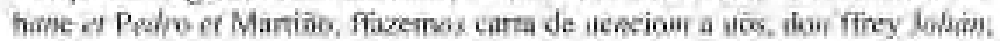
ahade de Mame de Rrusno, $e$ alo covoentiv desse lugar de quanta hardade

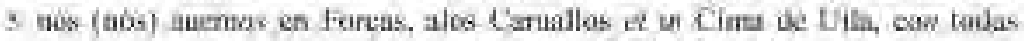

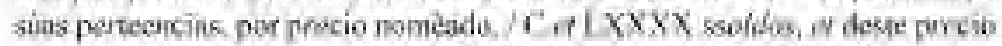

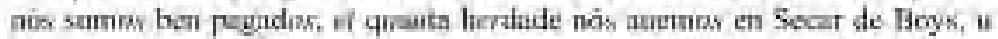

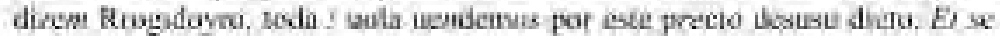

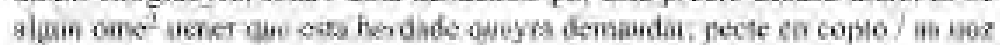

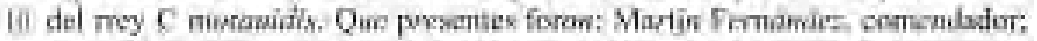

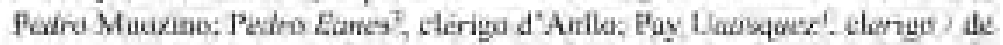

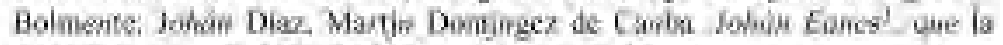

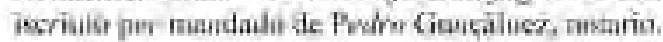

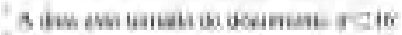

trer we animosakeiti.

Bes caran.

newrarem ivipe
} 


\section{3}

1259, Narzo.

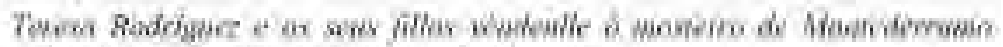

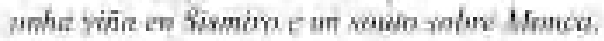

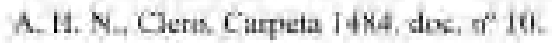

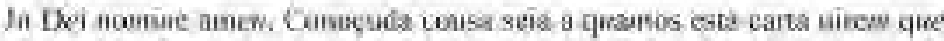

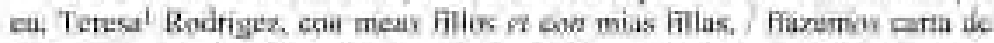

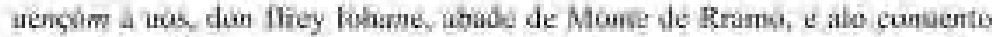

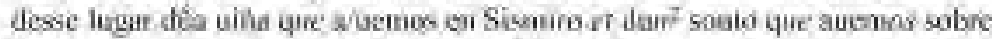

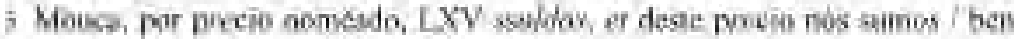

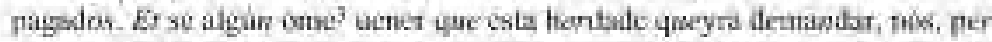

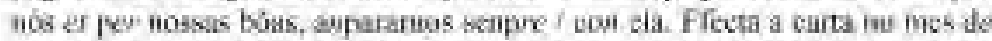

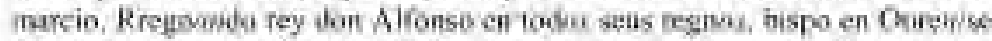

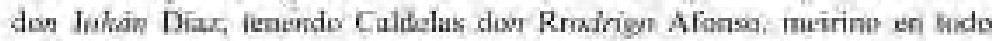

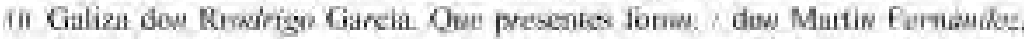

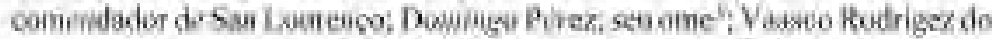

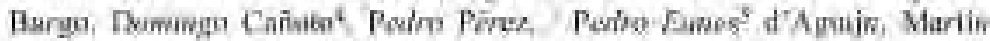

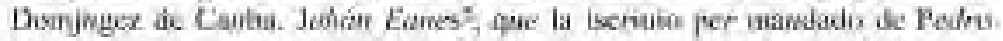

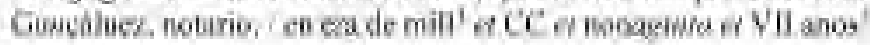

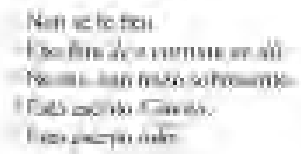

\section{4}

1263, Abrit. 10.

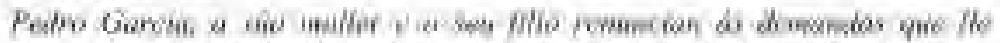

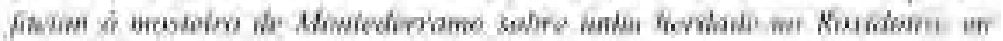
Sicurationis

\section{A. C Ourenses Tondo de Perdunieos Monacass, ơ on}

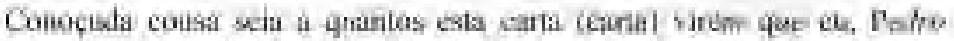

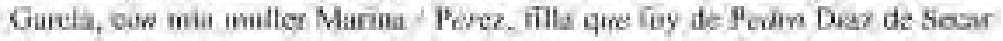

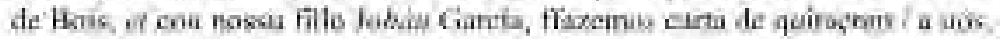

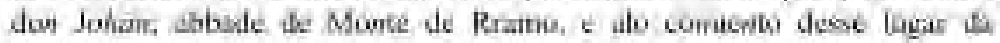

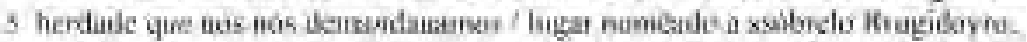

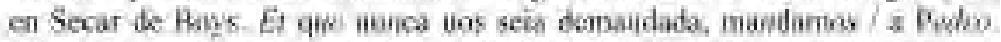

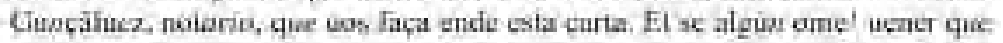




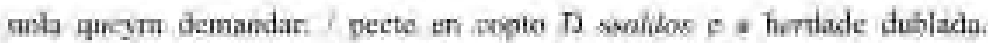

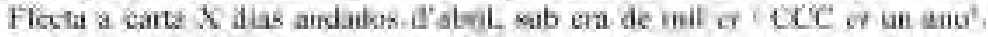

14. Rregrander ref doit Affouso en Leen ef en Castela we en todas saus reynos,

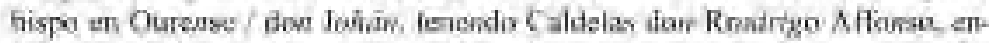

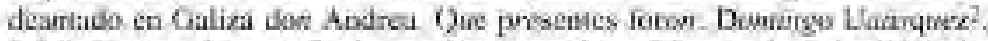

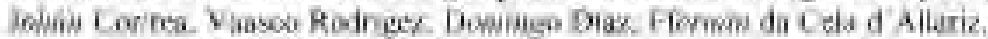

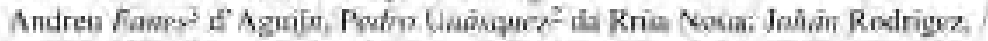

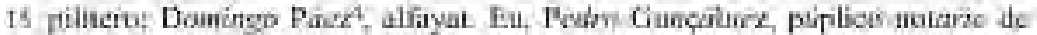

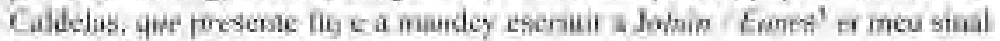
hy feoo isiGNOy.

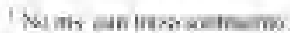

fe esrativis

Easominitiv

t Fod serio is
}

1264. Xй64, 15.

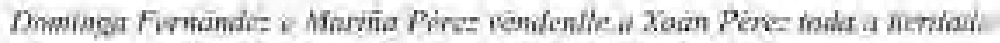

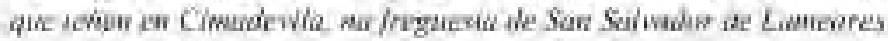

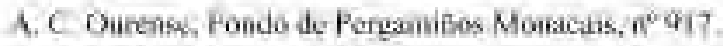

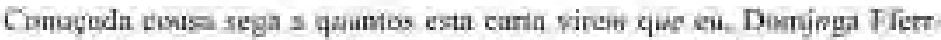

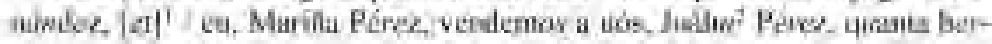

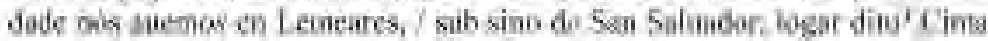

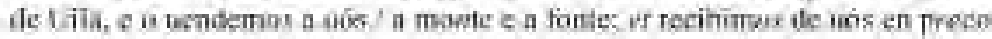

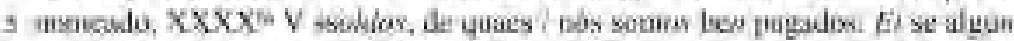

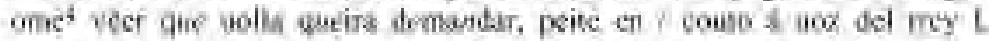

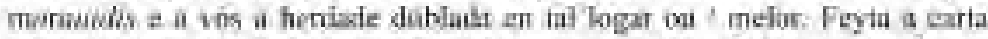

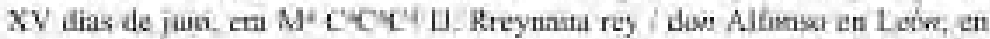
Castellar bispu so Oerense dow bahon Diaz. teendo Caildelas do[n]' Rodert-

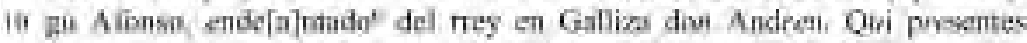

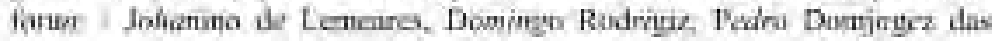

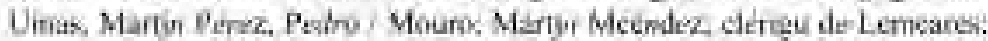

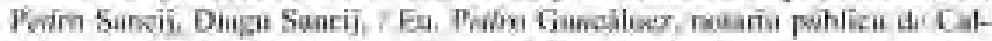

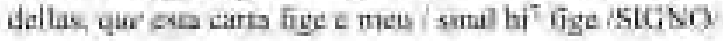

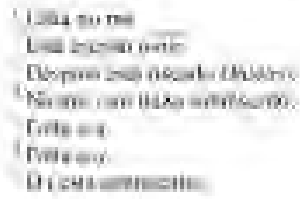




\section{4, Decembari, 14.}

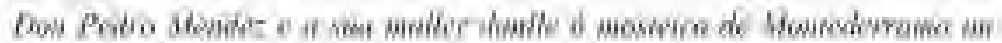

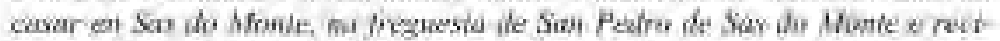

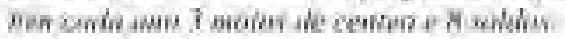

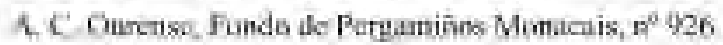

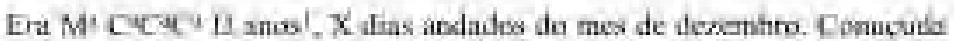
cousa sega u quansos orla carsa virem que eu; dism Pedho Meewilez, enson-

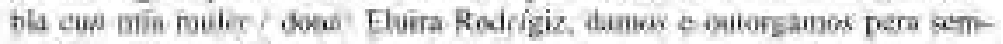

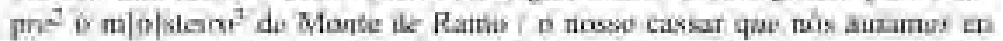

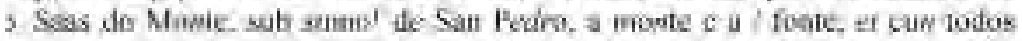

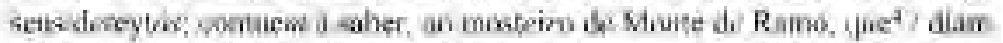

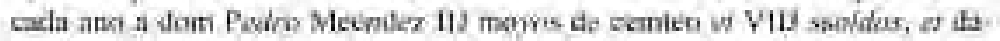

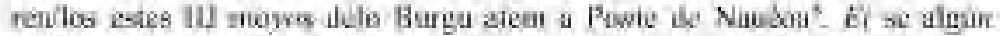

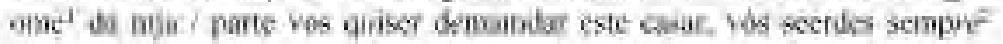

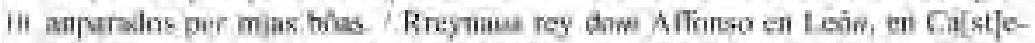

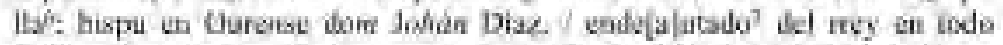

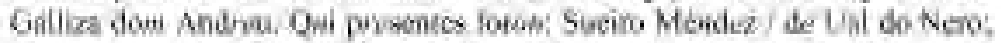

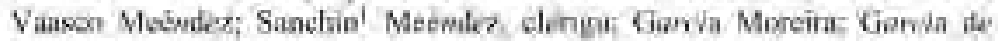

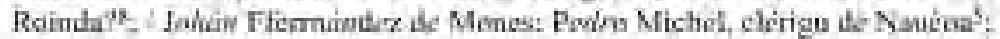

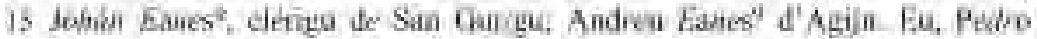

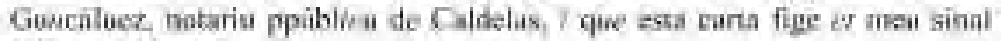
his tive ISIG NON,

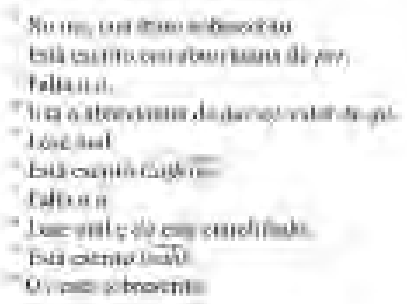




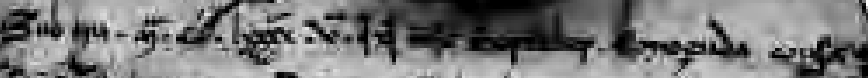

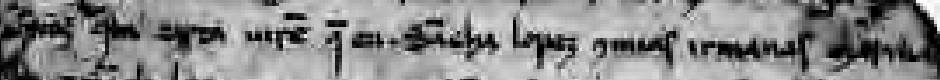

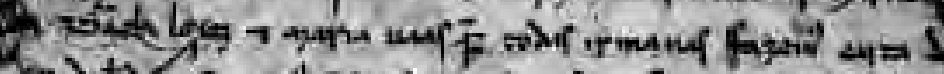

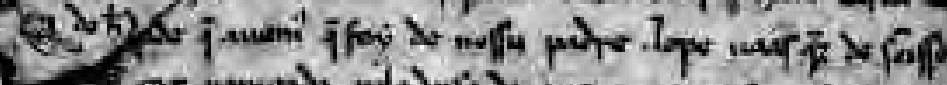

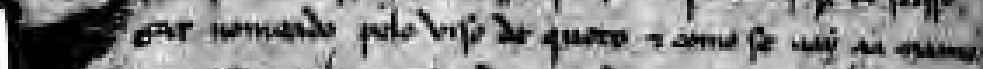

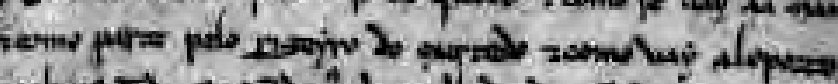

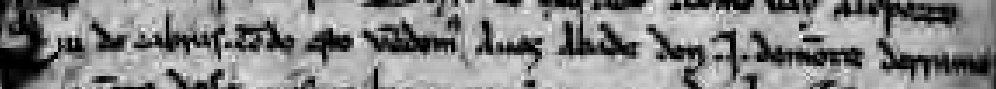

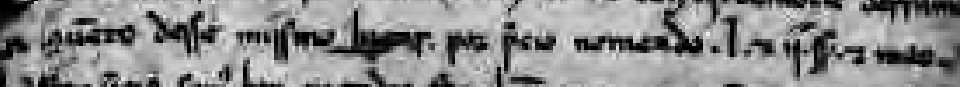

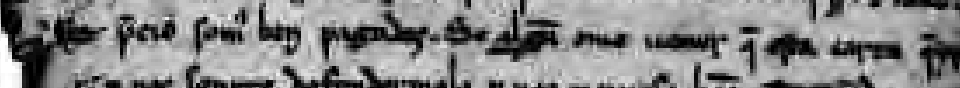

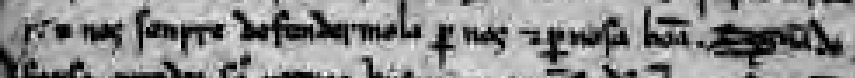

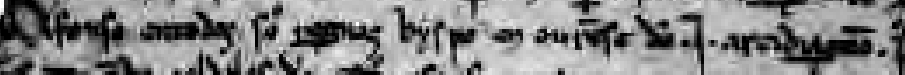

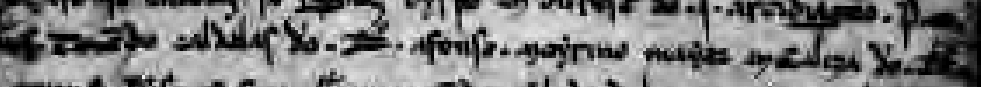

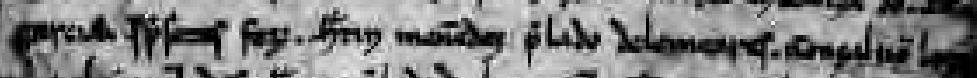

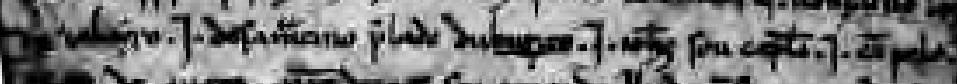

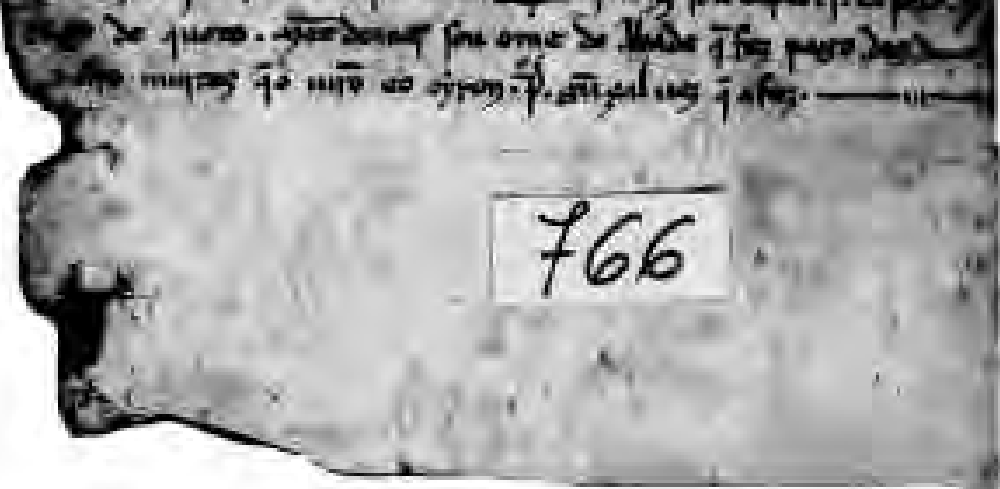




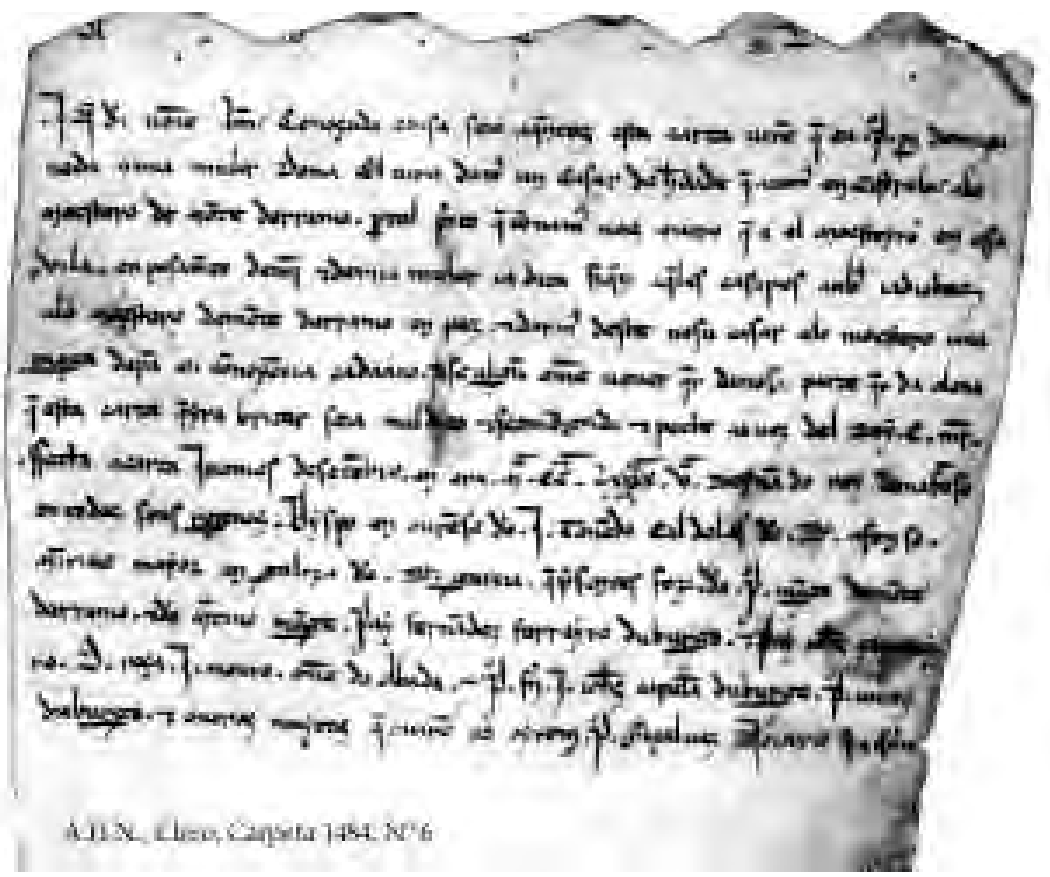




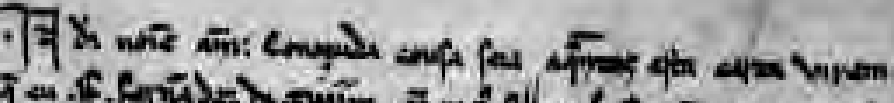

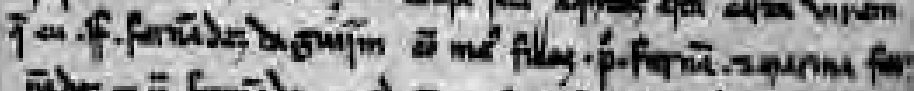

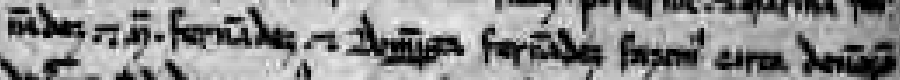

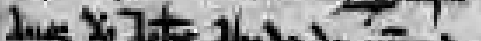

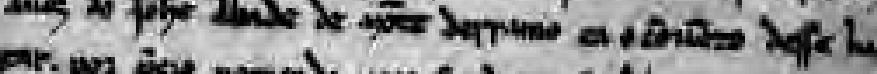

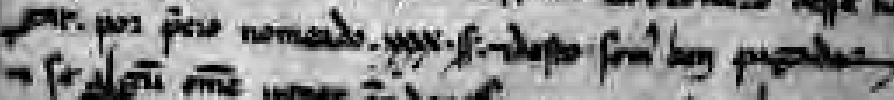

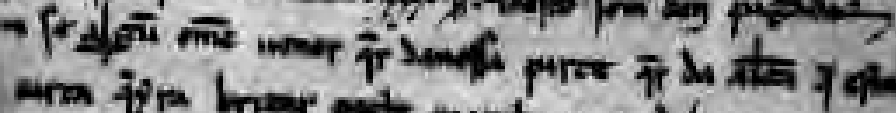

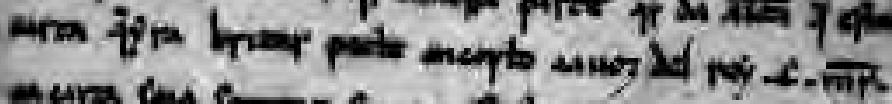

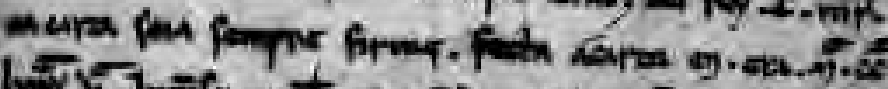

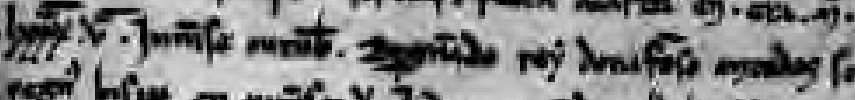

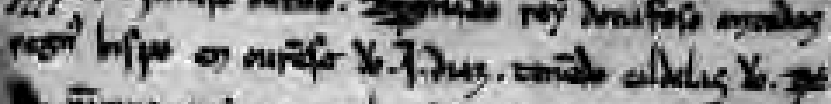

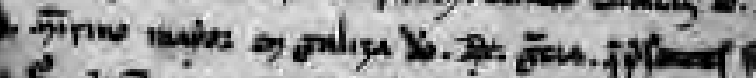

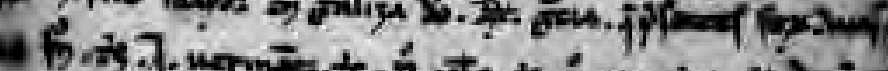

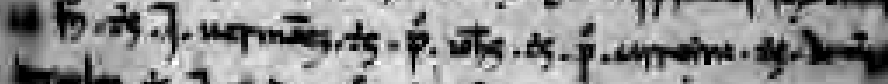

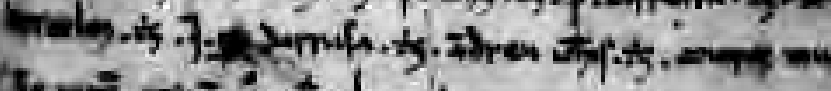

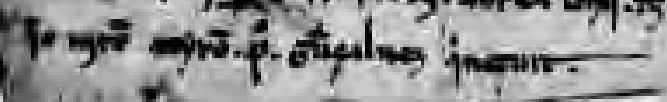




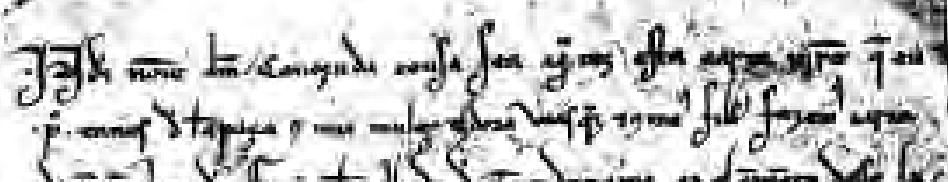

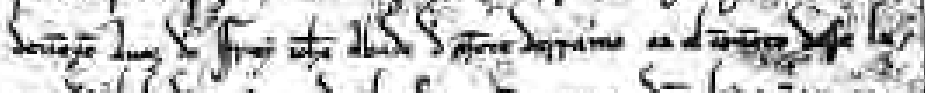

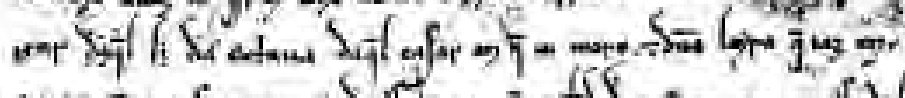

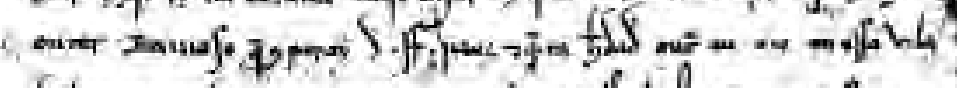

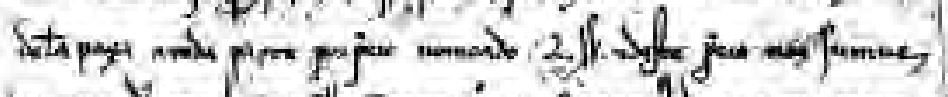

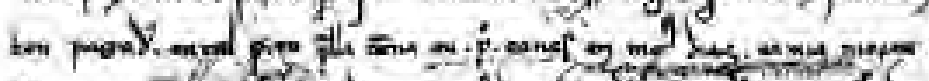

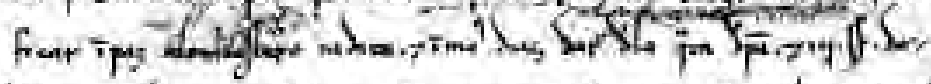

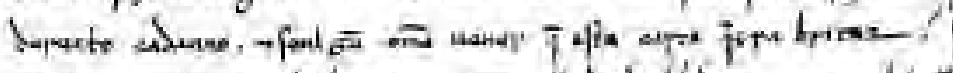

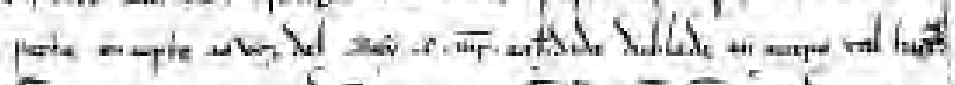

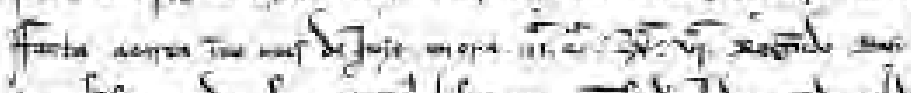

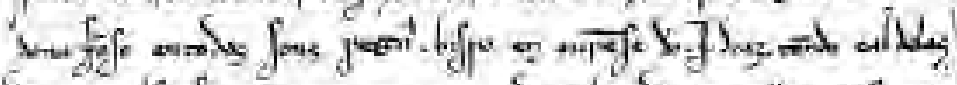

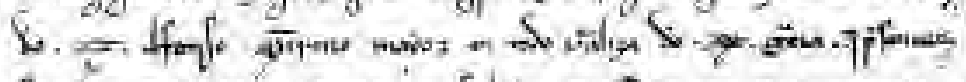

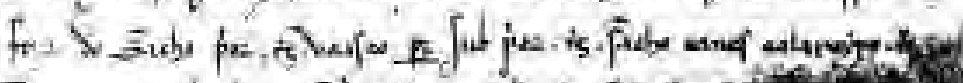

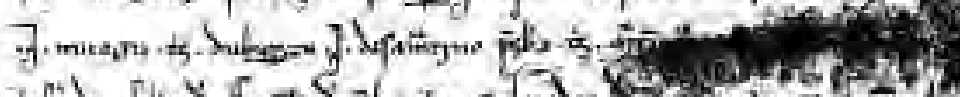

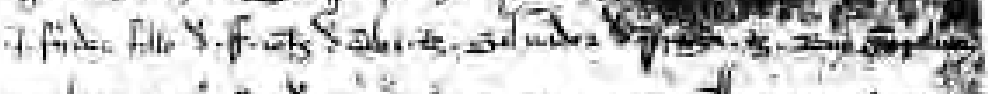

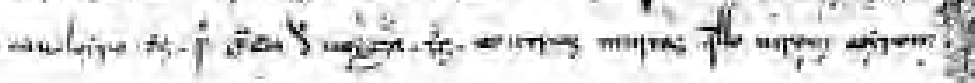

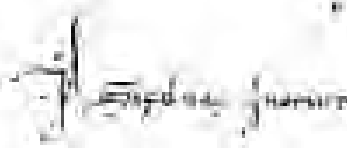




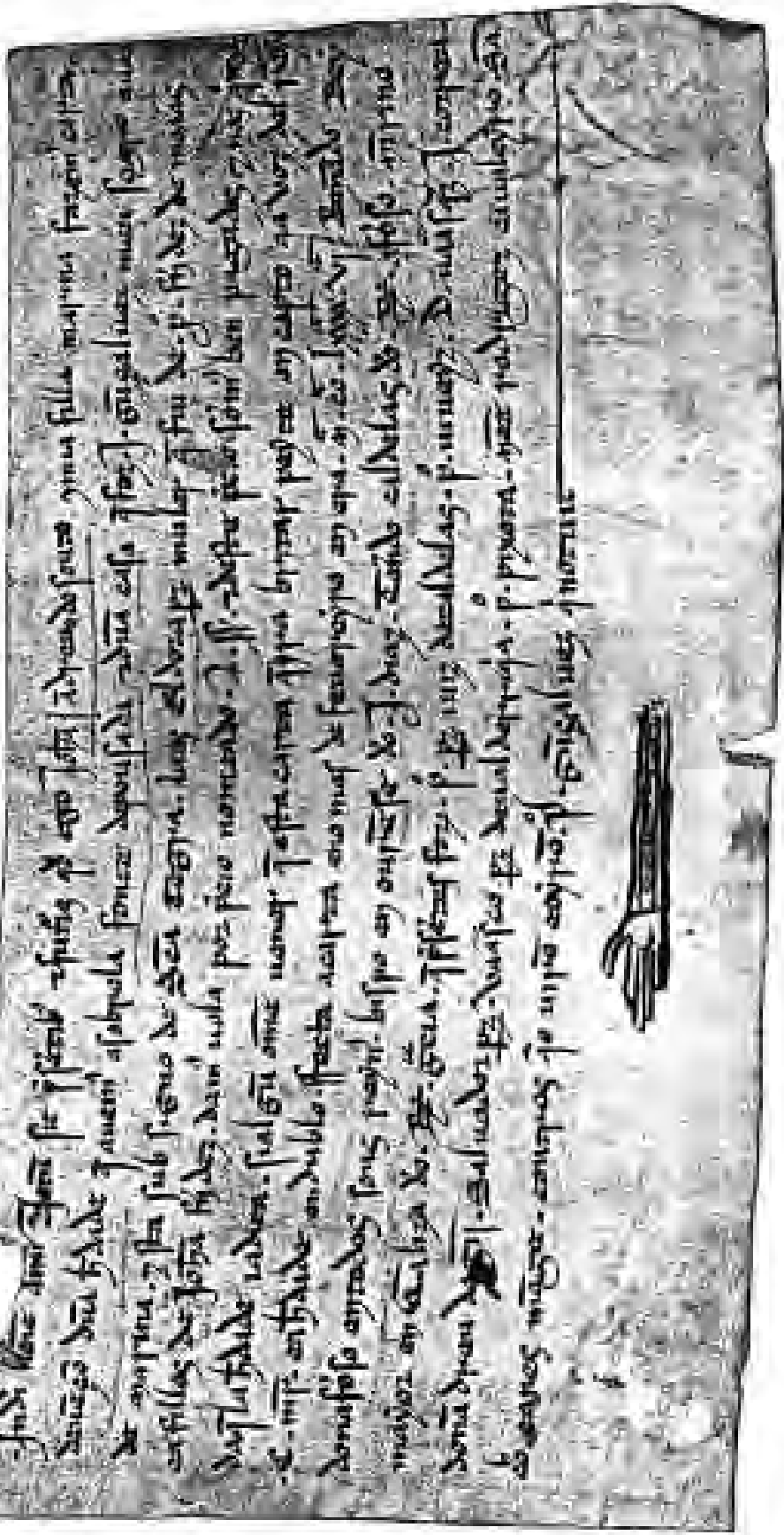




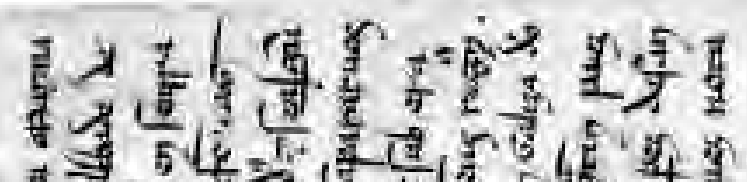

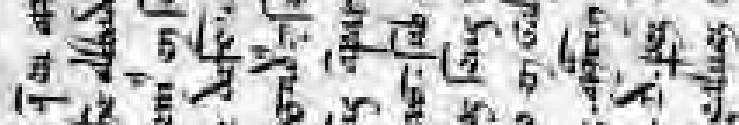

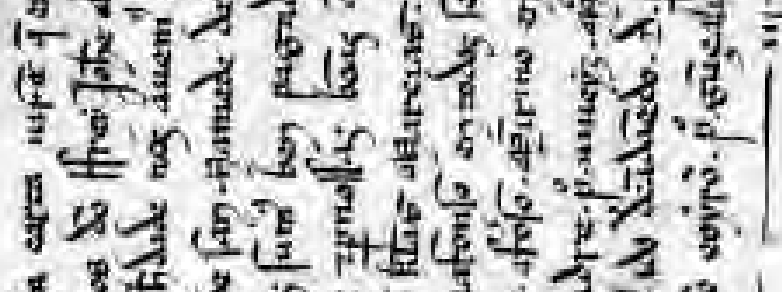

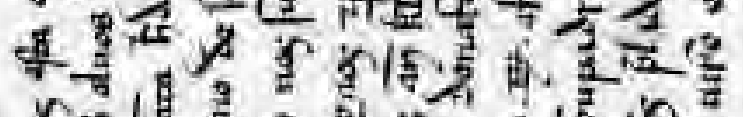

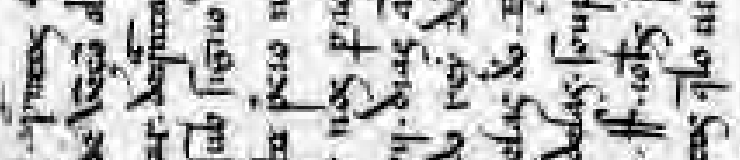

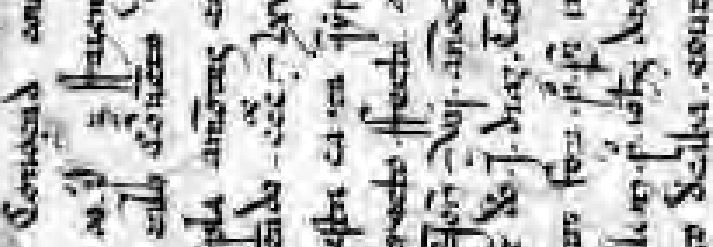

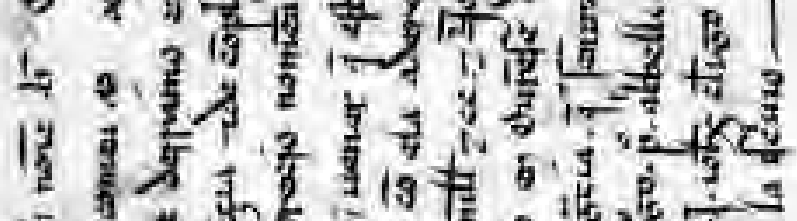

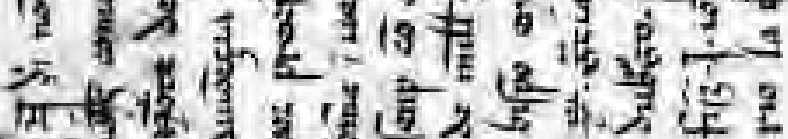

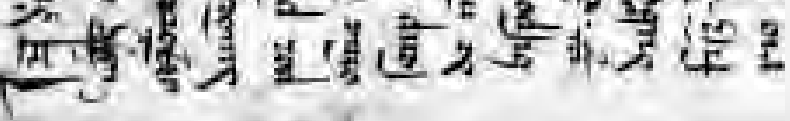




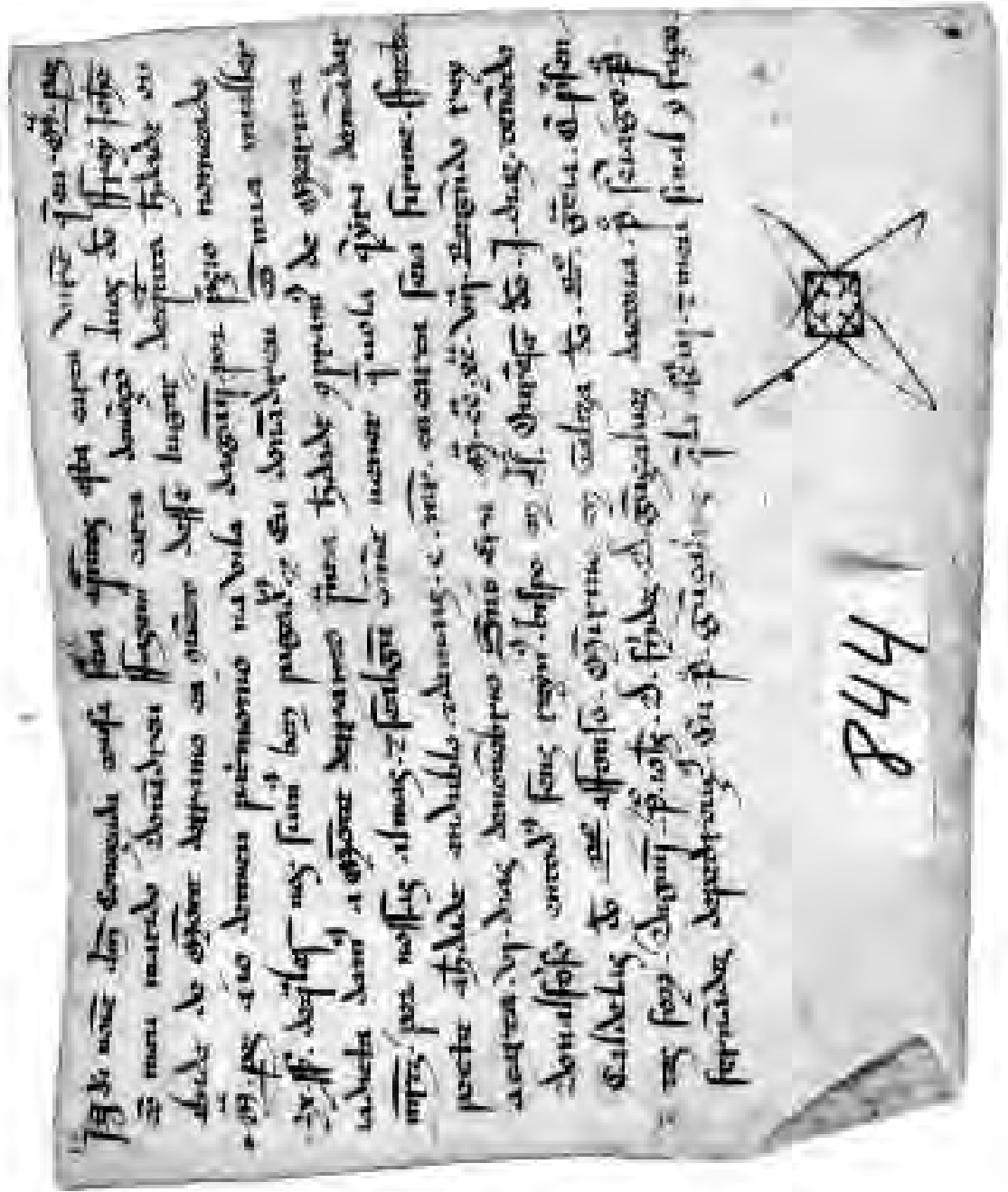




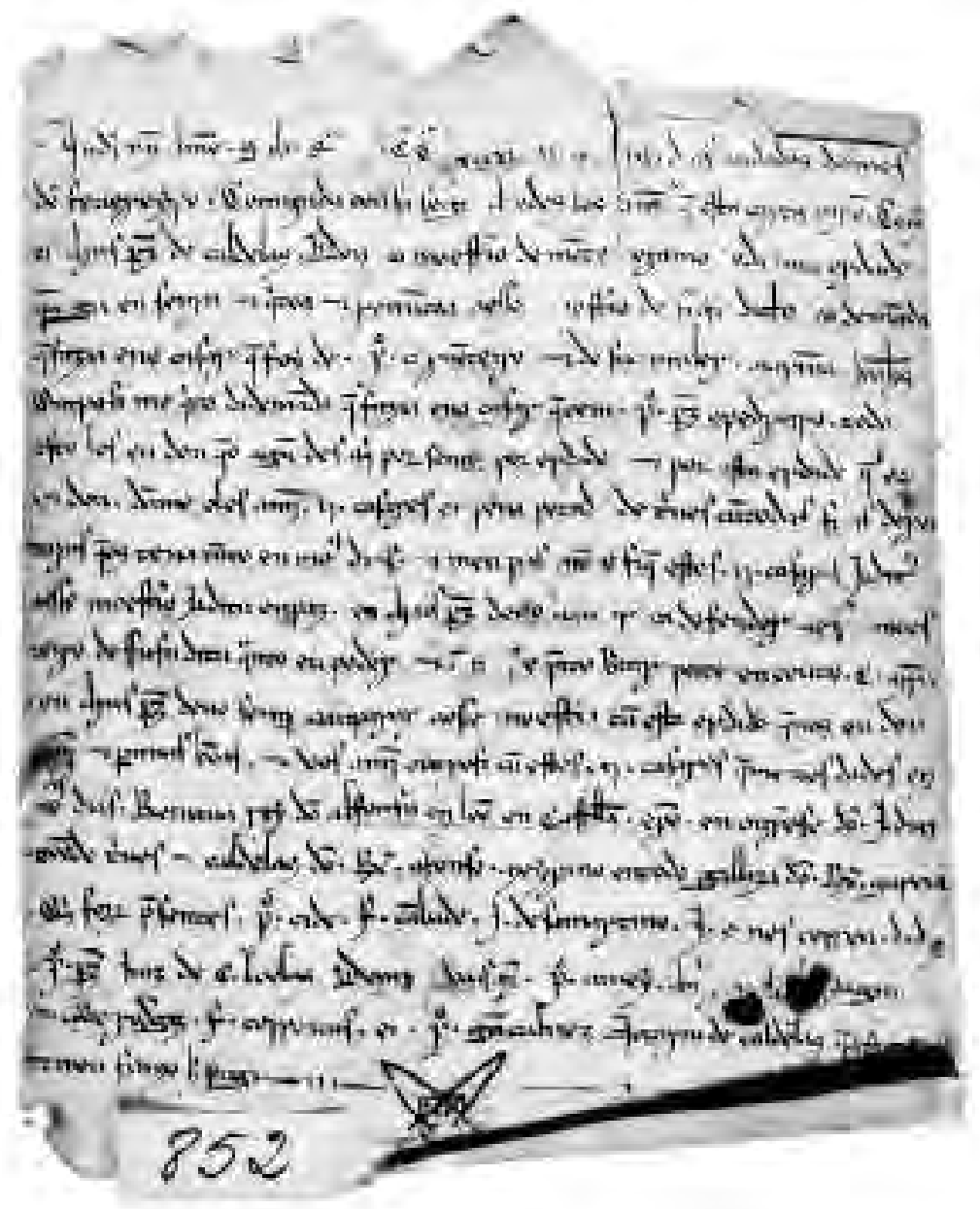




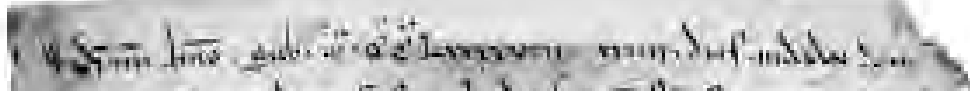

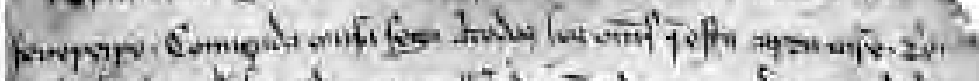

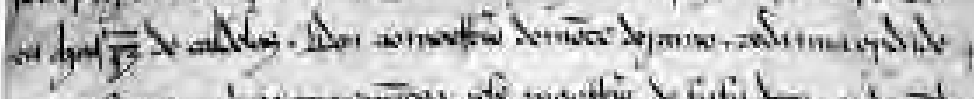

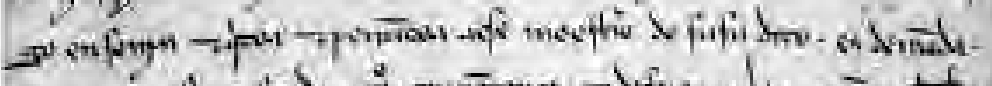
If

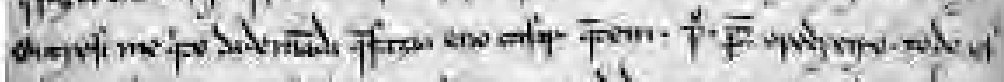

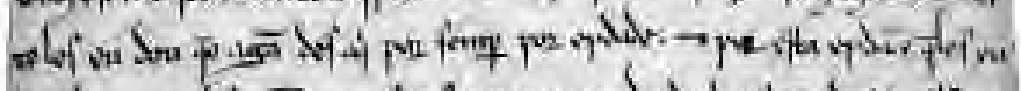

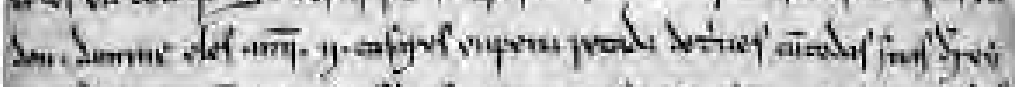

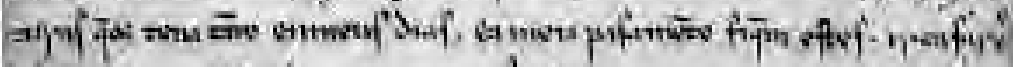

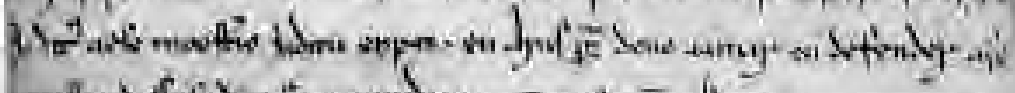

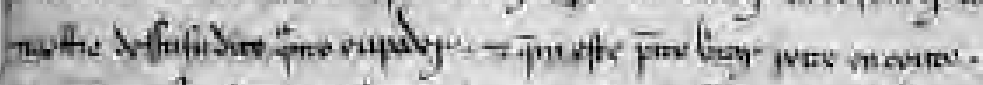

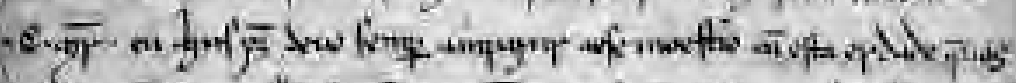

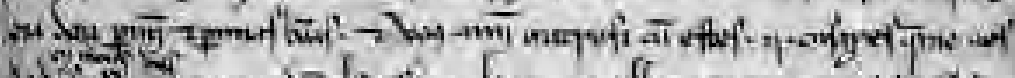

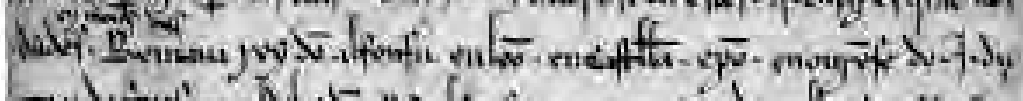

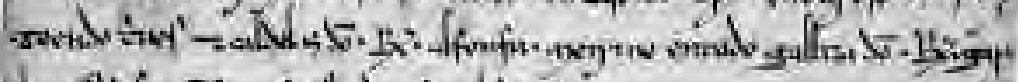

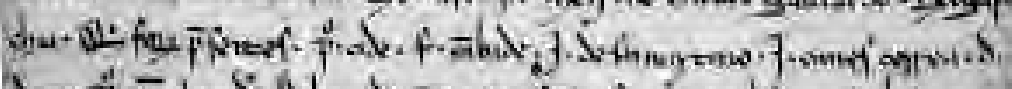

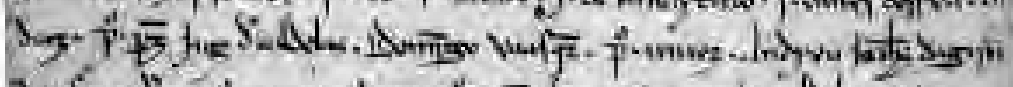

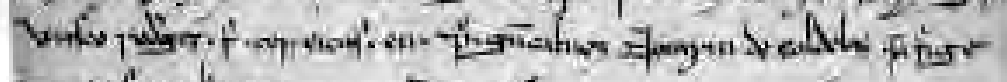

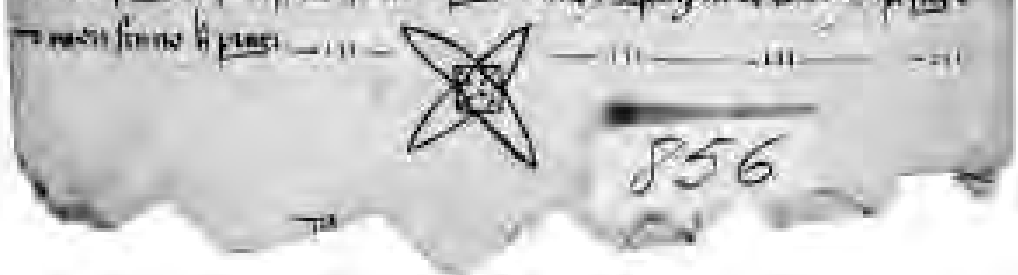




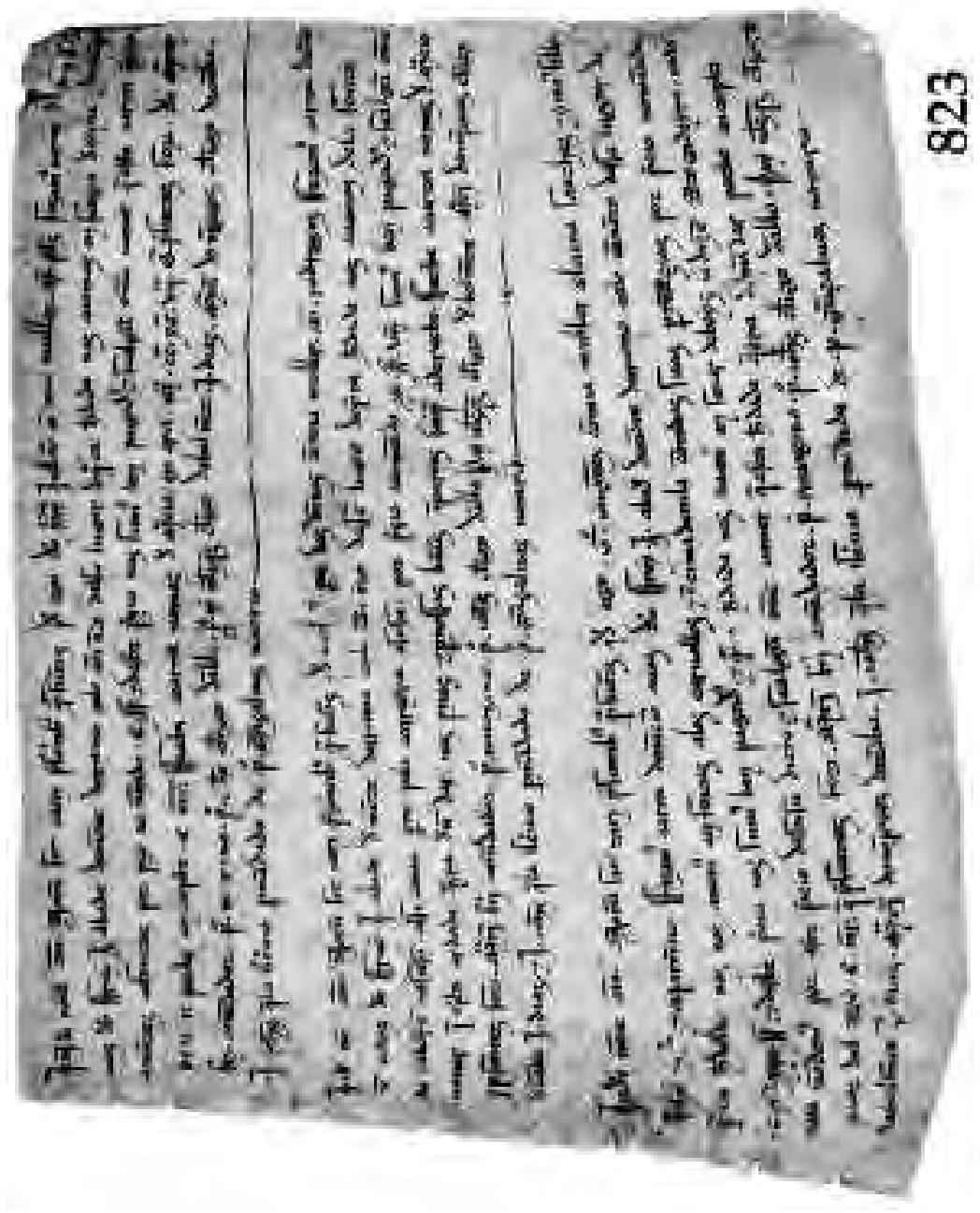




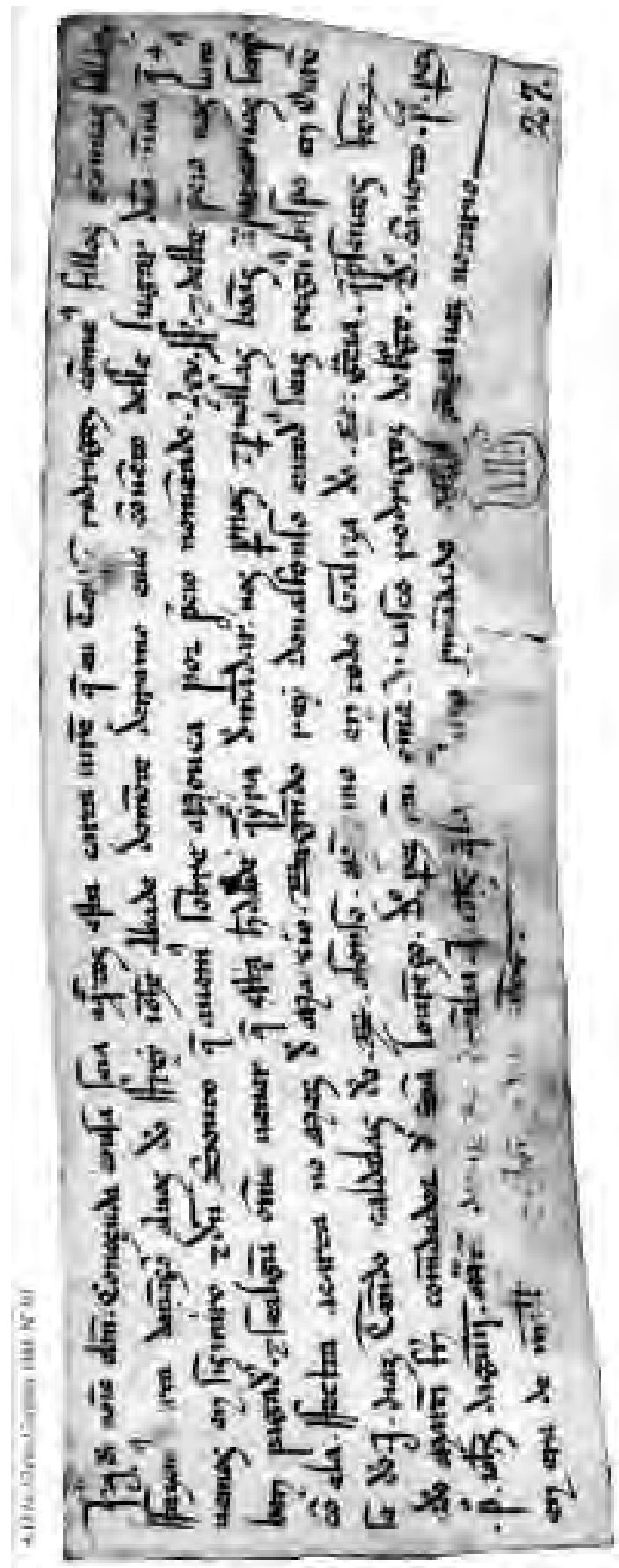




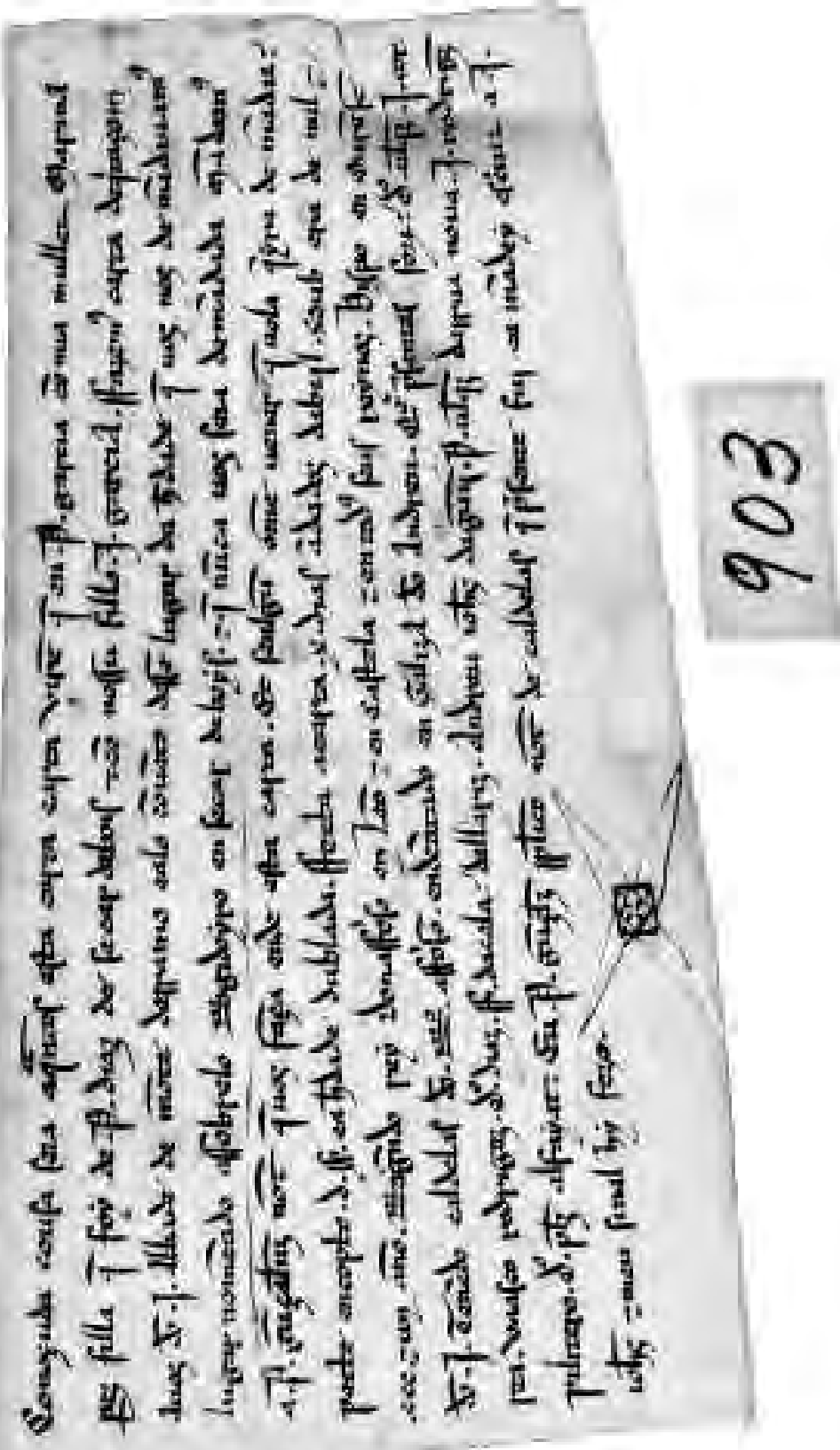




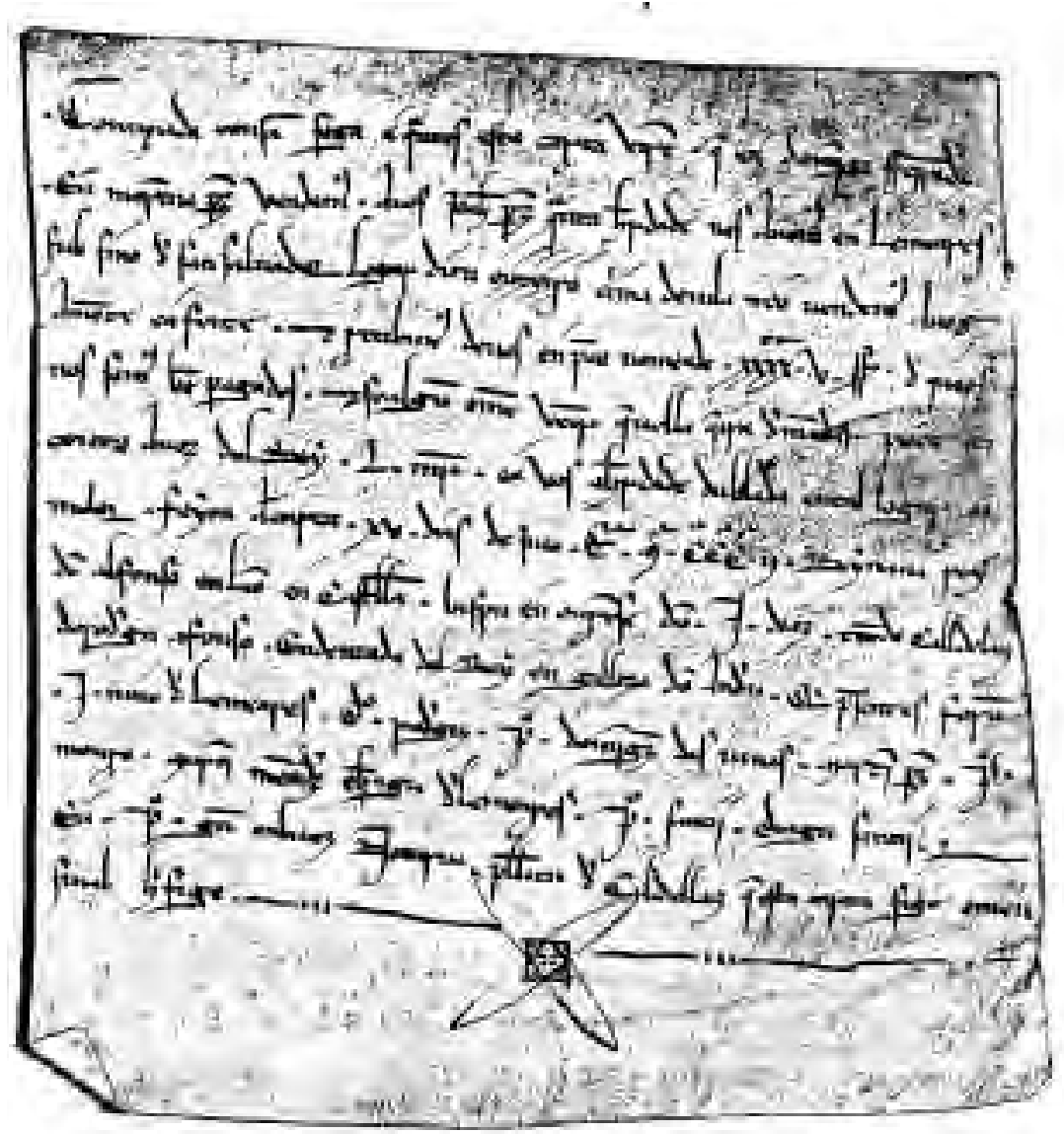




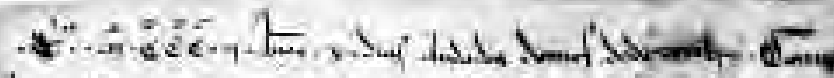

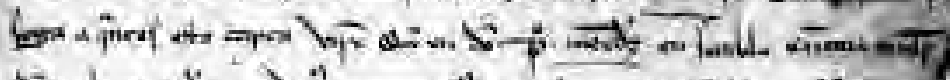

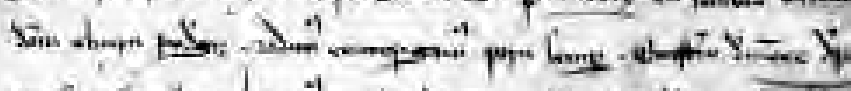

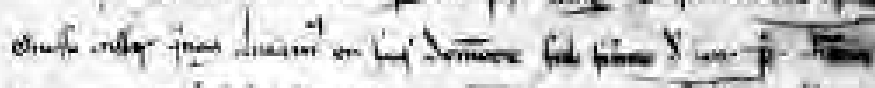

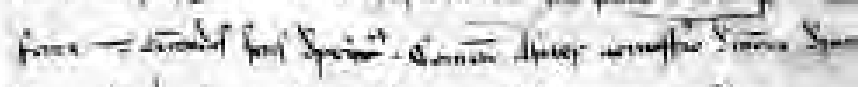

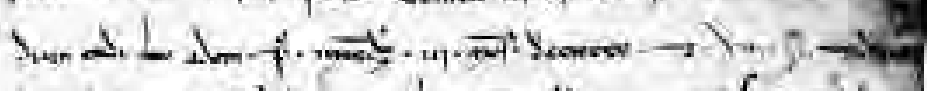
by

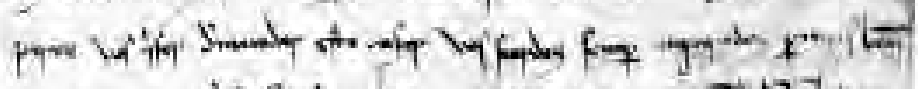

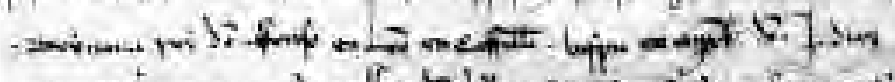

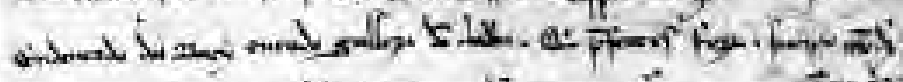

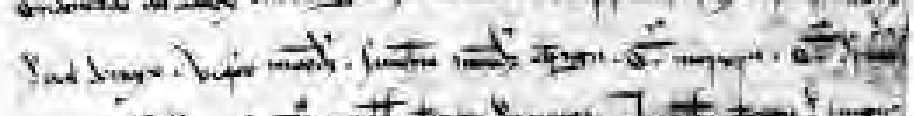

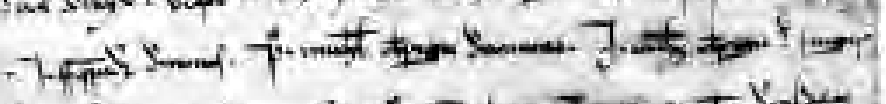

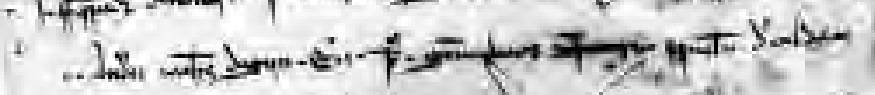
1 an $a 9^{6}$ 